\title{
The Constitutional Implications of Human Cloning
}

\author{
Elizabeth Price Foley \\ Florida International University College of Law
}

Follow this and additional works at: https://ecollections.law.fiu.edu/faculty_publications

Part of the Constitutional Law Commons

\section{Recommended Citation}

Elizabeth Price Foley, The Constitutional Implications of Human Cloning , 42 Ariz. L. Rev. 647 (2000).

Available at: https://ecollections.law.fiu.edu/faculty_publications/413 


\section{HEINONLINE}

DATE DOWNLOADED: Mon Jul 13 16:11:09 2020

SOURCE: Content Downloaded from HeinOnline

Citations:

Bluebook 20th ed.

Elizabeth Price Foley, The Constitutional Implications of Human Cloning, 42 Ariz. L. Rev. 647 (2000).

ALWD 6th ed.

Elizabeth Price Foley, The Constitutional Implications of Human Cloning, 42 Ariz. L.

Rev. 647 (2000).

APA 7th ed.

Foley, E. (2000). The constitutional implications of human cloning. Arizona Law

Review, 42(3), 647-730.

Chicago 7th ed.

Elizabeth Price Foley, "The Constitutional Implications of Human Cloning," Arizona

Law Review 42, no. 3 (2000): 647-730

McGill Guide 9th ed.

Elizabeth Price Foley, "The Constitutional Implications of Human Cloning" (2000) 42:3

Ariz L Rev 647.

MLA 8th ed.

Foley, Elizabeth Price. "The Constitutional Implications of Human Cloning." Arizona

Law Review, vol. 42, no. 3, 2000, p. 647-730. HeinOnline.

OSCOLA 4th ed.

Elizabeth Price Foley, 'The Constitutional Implications of Human Cloning' (2000) 42

Ariz L Rev 647

Provided by:

FIU College of Law

-- Your use of this HeinOnline PDF indicates your acceptance of HeinOnline's Terms and Conditions of the license agreement available at https://heinonline.org/HOL/License

-- The search text of this PDF is generated from uncorrected OCR text.

-- To obtain permission to use this article beyond the scope of your license, please use: Copyright Information 


\title{
THE CONSTITUTIONAL IMPLICATIONS OF HUMAN CLONING
}

\author{
Elizabeth Price Foley*
}

\section{INTRODUCTION}

True to science fiction writer Aldous Huxley's prediction, humankind recently entered a Brave New World.' In January 1997, scientists at the Roslin Institute in Scotland annouriced that they had successfully cloned an adult sheep, producing a now famous, fuzzy-faced offspring named "Dolly." Not since the ground-breaking work of Gregor Mendel, a mid-nineteenth century monk who founded the science of heredity, ${ }^{2}$ had genetic understanding made such a large leap.

The Scottish breakthrough was not greeted warmly. Medical ethicists, ${ }^{3}$ religious leaders ${ }^{4}$ and scientists ${ }^{5}$ quickly took to the airwaves to proclaim the

* Professor of Law, Michigan State University, Detroit College of Law; B.A., Emory University; J.D., University of Tennessee; LL.M., Harvard Law School. I am grateful for the limitless, cheerful support of my husband, Patrick Foley. I am also indebted to my excellent research assistant, Donald Nystrom, J.D. (2000), as well as Michigan State University, Detroit College of Law, for the research stipends that supported the completion of this Article.

1. Aldous HuXLEY, BRAVE NEW WORD (1932). Huxley's novel envisions a eugenic society where cloning is the normal mode of procreation and the resulting clonants-classified as Alphas, Betas, Deltas, Gammas or Epsilons, depending on their genetic heritage-are genetically bred to perform certain functions. (1965).

2. See generally Gregor Mendel, ExPERIMENTS In Plant Hybridization

3. See, e.g., George J. Annas, Human Cloning: Should the United States Legislate Against It? Yes: Individual Dignity Demands Nothing Less, A.B.A. J., May 1997, at 80 (stating that "[h]uman cloning should be banned because it would radically alter our very definition of ourselves by producing the world's first human with a single genetic parent").

4. See, e.g., Religious Leaders Oppose Human Cloning, UPI, Jan. 9, 1998, available in LEXIS, News Library, UPI File (reporting that the Reverend Frank Pavone, a Catholic priest in New York, believes the Catholic church is opposed to human cloning and that the Reverend Ronald Cole-Tumer of the United Church of Christ condemned human cloning as "blasphemous"); Human Cloning Termed "Adulterous" Under Islamic Law, NATIONWIDE GEN. NEwS, Jan. 10, 1998, available in LEXIS, News Library, News Group 
practice immoral or unethical for the human race. President Clinton issued an Executive Order banning the use of federal funding for human cloning research ${ }^{6}$ and urged the American scientific community to refrain voluntarily from pursuing human cloning research until such time as the National Bioethics Advisory Commission ("NBAC") could study the issue."

In June 1997, the NBAC issued its report which concluded that human cloning was "morally unacceptable" and recommended the passage of a federal law banning the practice. ${ }^{8}$ The momentum against human cloning gained even more ground in January 1998, when physicist Richard Seed announced his intention to seek private funding to create the first human clone by the new millennium, proudly boasting that such an achievement would be mankind's "first serious step in becoming one with God." Condemnation of Seed's intentions was swift. $^{10}$ The U.S. Secretary of Health and Human Services Donna Shalala pronounced Seed a "mad scientist" who must be stopped." President Clinton, moreover, announced in his weekly radio address:

This week, like many Americans, I learned the profoundly troubling news that a member of the scientific community is actually laying plans to clone a human being. Personally, I believe that human cloning raises deep concerns, given our cherished concepts of faith and humanity. Beyond that however, we know there is virtually

File, Beyond Two Years (reporting that a panel of legal and medical experts in the United Arab Emirates declared human cloning to be adultery under Islamic law).

5. See, e.g., Diane M. Gianelli, Presidential Panel Advocates Ban on CloningFor Now, AM. MED. NEws, June 23/30, 1997, at 22 (reporting that the American Society for Reproductive Medicine had issued a statement characterizing human cloning as "unacceptable").

6. See Memorandum on the Prohibition on Federal Funding for Cloning of Human Beings, 33 WeEkLY COMP. PREs. Doc. 281 (Mar. 4, 1997). Although federal funding of human embryo research had been banned since December 1994, President Clinton decided that because "these restrictions do not explicitly cover human embryos created for implantation and do not cover all Federal agencies," an order specifically prohibiting federal funding of human cloning research was needed. Id.

7. See Remarks Announcing the Prohibition on Federal Funding for Cloning of Human Beings and an Exchange With Reporters, 33 WeEkLY COMP. PRES. DOC. 278 (Mar. 4, 1997).

8. See Cloning human Beings: Report and Recommendations of the NATIONAL BIOETHICS ADVISORY COMMISSION 108-09 (1997) [hereinafter NBAC REPORT].

9. Human Cloning Within Two Years? Chicago Scientist Talks of "Becoming One With God," S.F. EXAMINER, Jan. 7, 1998, at A1 (reporting that Seed told NPR, "God made man in his own image. God intended for man to become one with God. . . Cloning and the reprogramming of DNA is the first serious step in becoming one with God."). Seed has reported that he intends to raise $\$ 2$ million to begin a for-profit human cloning center to assist infertile couples in their quest to have a child. Id.

10. See 144 CONG. REC. S605 (daily ed. Feb. 11, 1998) (statement of Sen. Helms); see also Gary Heinlein, Anti-Cloning Bills Are Proposed, DETROIT NEWs, Jan. 13, 1998, at D1; E.J. Dionne, Cloning's Cosmic Questions, DENVER POST, Jan. 13, 1998, at B9. A15.

11. A Cloning Plan Leads to Vows to Outlaw It, N.Y. TIMES, Jan. 12, 1998, at 
unanimous consensus in the scientific and medical communities that attempting to use these cloning techniques to actually clone a human being is untested and unsafe and morally unacceptable. ... [I]t is clearer now than ever that legislation is exactly what is needed. The vast majority of scientists and physicians in the private sector have refrained from using these techniques improperly. And have risen up to condemn any plans to do so. But we know it's impossible for some to ignore the consensus of their colleagues and proceed without regard for our common values. So, today again I call on Congress to act now, to make it illegal for anyone to clone a human being....12

Responding in a miasma of public fear and condemnation, members of Congress on both sides of the political aisle introduced bills to ban all research into human cloning, whether publicly or privately funded..$^{13}$ In addition, legislators at the state level, fearful of congressional inaction or perhaps just wanting to capture political credit for a popular issue, also introduced bills to ban human cloning in their individual states. $^{14}$ Four states $^{15}$-California, ${ }^{16}$ Louisiana, ${ }^{17}$ Michigan, ${ }^{18}$ and Rhode Island ${ }^{19}$-have enacted cloning bans, as have twenty European nations. ${ }^{20}$

12. President Bill Clinton, Weekly Radio Address, Jan. 10, 1998.

13. See, e.g., H.R. 923, 105th Cong., 1st Sess. (1997); S. 1611, 105th Cong., 2d Sess. (1998); S. 1602, 105th Cong., 2d Sess. (1998); S. 1599, 105th Cong., 2d Sess. (1998).

14. See H.B. 2071, 47th Leg., 2d Sess. (Okla. 2000); S.B. 476, 82d Reg. Sess. (Ark. 1999); H.B. 5042, 1999 Reg. Sess. (Conn. 1999); S.B. 649, 91st Gen. Assembly, 1999-00 (Ill. 1999); S.B. 1394, 181 st Gen. Court, 1999 Reg. Sess. (Mass. 1999); A.B. 3026, 1999-00 Reg. Sessions (N.Y. 1999); S.B. 102, 123d Gen. Assembly, 1999-00 Reg. Sess. (Ohio 1999); S.B. 794, 70th Leg. Assembly, 1999 Reg. Sess. (Or. 1999); H.B. 3036, 113th Sess. (S.C. 1999); H.B. 2418, 1999 Sess. (Va. 1999); S.B. 68, 1998 Reg. Sess. (Ala. 1998); H.B. 996, 1998 Reg. Sess. (Miss. 1998); H.B. 1237, 1997 Reg. Sess. (Fla. 1997); H.B. 2235, 90th Gen. Assembly, 1997-98 Reg. Sess. (Ill. 1997); A.B. 2849, 207th Leg. (N.J. 1997); S.B. 782, 1997 Sess. (N.C. 1997); S.B. 1017, 69th Leg., 1997 Reg. Sess. (Or. 1997); H.B. 7123, 1997-98 Leg. Sess. (R.I. 1997); S.B. 410, 73d Leg. (W. Va. 1997).

15. One additional state, Missouri, has enacted a ban on the use of state funds for use in human cloning research but has not enacted a total ban on cloning research activity. See Mo. ReV. STAT. § 1.217 (1999).

16. See CAL. HEALTH \& SAFETY CODE $\$ 24185$ (Deering 1997).

17. See LA. ReV. StAT. ANN. § 40:1299.36.2 (West 2000).

18. See S.B. 864, 89th Leg., 1997 Reg. Sess. (Mich. 1997) (providing for licensure revocation for any health care professional who clones or attempts to clone a human being); H.B. 4846, 89th Leg., 1997 Reg. Sess. (Mich. 1997) (defining cloning or attempting to clone a human being as "unprofessional conduct" for purposes of state health professional licensure law); H.B. 4962, 89th Leg., 1997 Reg. Sess. (Mich. 1997) (making it a felony, punishable by up to 10 years imprisonment and/or a fine of not more than $\$ 10$ million, to clone or attempt to clone a human being); H.B. 5475, 89th Leg., 1997 Reg. Sess. (Mich. 1997) (prohibiting the use of state funds for the purpose of human cloning).

19. See R.I. GEN. LAWS § 23-16.4-2 (1998).

20. See Human Cloning Banned in Britain, APpled Genetic News, July 1999, available in LEXIS, News Library, News Group File, Most Recent Two Years (reporting on the July 2, 1999, ban on human cloning enacted by Great Britain); Robert Davis, 
While the debate about the ethical and moral implications of human cloning rages on, surprisingly little discussion has occurred with regard to its myriad legal-particularly constitutional-implications. ${ }^{21}$ Indeed, although numerous articles have been written about human cloning in legal journals, there has been virtually no discussion regarding the legal and constitutional implications beyond procreative liberty and even less discussion regarding whether the governmental interests asserted thus far in support of banning the practice are sufficiently important to justify such drastic and sweeping action. And while no one has yet succeeded in cloning a human being, the consensus seems to be that there are no theoretical reasons why it cannot be done and that it is, therefore, only a matter of time. ${ }^{22}$

Given the theoretical inevitability of human cloning, this Article attempts to fill a current intellectual void by providing an analysis of the most significant legal implications of cloning human beings. Part II sets forth the basic science behind cloning and how cloning differs from other, non-traditional forms of procreation such as in vitro fertilization and artificial insemination. Part III discusses the most commonly feared "science fiction" abuses associated with human cloning and current laws that may prevent such abuses from occurring. Part IV discusses the possible constitutional impediments to banning human cloning, including the First Amendment, the procreational liberty interest of the Due Process Clause, and the Equal Protection Clause. ${ }^{23}$ Part V considers the possible

Nineteen Countries Ban Human Cloning, USA TODAY, Jan. 13, 1998, at 1D (stating that Denmark, Estonia, Finland, France, Greece, Iceland, Italy, Latvia, Luxembourg, Macedonia, Moldovia, Norway, Portugal, Romania, San Marino, Slovenia, Spain, Sweden, and Turkey have banned human cloning).

21. Many of the law journal articles published thus far have been written as student notes or comments. See Jennifer Cannon \& Michelle Haas, Note, The Human Cloning Prohibition Act: Did Congress Go Too Far?, 35 HARV. J. ON LEGIS. 637 (1998); Note, Human Cloning and Substantive Due Process, 111 HARv. L. Rev. 2348 (1998); Francis C. Pizzulli, Comment, Asexual Reproduction and Genetic Engineering: A Constitutional Assessment of the Technology of Cloning, 47 S. CAL. L. REV. 476 (1974); Lawrence Wu, Note, Family Planning Through Human Cloning: Is There a Fundamental Right?, 98 CoLUM. L. REV. 1461 (1998). Most articles written thus far by academics focus exclusively (or nearly so) on ethical considerations and whether or not cloning would fall within a fundamental right of procreation, with little or no discussion of other important constitutional provisions that may be affected. See generally George J. Annas, Human Cloning: A Choice or an Echo?, 23 U. DAYTON L. Rev. 247 (1998); Ronald Chester, To Be, $\mathrm{Be}, \mathrm{Be}$. . . Not Just to Be: Legal and Social Implications of Cloning for Human Reproduction, 49 FlA. L. REv. 303 (1997); Debra Feuerberg Duffy, To Be or Not to Be: The Legal Ramifications of the Cloning of Human Embryos, 21 RUTGERS COMPUTER \& TECH. L. J. 189 (1995); Anne Lawton, The Frankenstein Controversy: The Constitutionality of a Federal Ban on Cloning, 87 KY. L. J. 277 (1998); John A. Robertson, Liberty, Identity, and Human Cloning, 76 TEX. L. REV. 1371 (1998).

22. See, e.g., Gina Kolata, On Cloning Humans, "Never" Turns Swiflly into "Why Not," N.Y. TIMES, Dec. 2, 1997, at Al.

23. Another intriguing constitutional question-specifically, whether the government would have power to legislate in this area pursuant to the Commerce Clauseis beyond the scope of this Article. Suffice it to say here that a complex question exists as to 
governmental interest in regulating human cloning to assess whether such regulation would survive the applicable level of judicial scrutiny. The Article concludes that, contrary to popular public opinion, the current legal regime appears prepared to handle human cloning. Moreover, should Americans wish to ban the practice, they may not be able to do so consistent with the current Constitution. ${ }^{24}$

\section{The SCIENCE OF CLONING}

Cloning is an asexual form of procreation. ${ }^{25}$ That is to say, it is a manner of procreation which does not require the sexual union of sperm and egg in order to begin the process of cell division, which ultimately leads to the formation of a new living creature. ${ }^{26}$ All other known methods of procreation-sexual intercourse, artificial insemination, ${ }^{27}$ and in vitro fertilization ("IVF") ${ }^{28}$-are

whether, in light of the Supreme Court's recent decision in United States v. Lopez, 514 U.S. 549 (1995) and its progeny, regulation of human cloning-a medical procedure traditionally within state concern-would fall within the congressional commerce power.

24. Thus, an amendment to the current Constitution may be necessary in order to carry out a desire to ban human cloning. A constitutional amendment requires approval by two-thirds of both Houses of Congress, as well as ratification by three-quarters of the state legislatures. U.S. CONST. art. V.

25. "Procreation" is generally defined as "propagation," "reproduction," or the "begett[ing] or bring[ing] forth [of] offspring." See WeBSTER's NEW COLLEGIATE DICTIONARY 910 (1981). One commentator has suggested that human cloning would be more properly characterized as "replication" rather than "procreation," since the child born would be an exact genetic duplicate of an existing human. See Annas, supra note 21, at 254; Annas, supra note 3 , at 80 . While it is undoubtedly true that cloning involves replication, its replicative nature is not antithetical to the term "procreation," any more than it is with the birth of "natural" twins or triplets. The attempt to find a new shibboleth other than "procreation" to describe human cloning is a poorly disguised attempt to redefine procreation so as to eliminate methods one deems morally, ethically or socially undesirable.

26. See Thomas W. Hilgers, The New Technologies of Birth and Death, in THE New Technologies of BirTh and Death: Medical, Legal and Moral Dimensions 29, 46-47 (1980); see also Genetic Engineering: Evolution of a Technological Issue, Report to the Subcomm. on Science, Research and Development of the House Comm. on Science and Astronautics, 92d Cong., 2d Sess. 21-22 (1972).

27. Artificial insemination is the process of injecting viable sperm into a uterus. MARGOT JOAN Fromer, ETHICAL ISSUES IN SEXUALITY AND REPRODUCTION 262 (1983). It can be accomplished in two ways: (1) by injecting sperm from the husband, whose sperm count is too low to bring about a successful coital fertilization-called artificial insemination by husband (AIH); and (2) by injecting sperm from a donor whose sperm is determined to be viable-called artificial insemination by donor (AID). See id. at 263 .

28. In vitro fertilization is the process whereby a woman's egg is removed and joined with viable sperm inside a petri dish. The fertilized egg is then re-implanted into the womb. See id. at 271 . Children conceived by IVF were initially referred to as "test tube babies," the most famous of which was the child named Louise Brown, born in the summer of 1978. See Peter Gwynne, et al., All About That Baby, NewsweEk, Aug. 7, 1978, at 66. 
sexual forms of procreation because they rely upon the "sperm meets egg" miracle to ignite the spark of life. ${ }^{29}$

The cloning performed by the Scottish scientists at the Roslin Institute was remarkable because it was the first time that scientists had successfully cloned any kind of animal from an adult or "differentiated" cell. ${ }^{30}$ Prior cloning had been successfully performed by splitting embryonic or "undifferentiated" (totipotent) cells-cells which have not yet lost their ability to differentiate themselves into the numerous body parts that form living organisms such as ears and eyes and tongues. ${ }^{31}$ Since the early 1950 s, however, embryonic cell cloning has been successfully performed on numerous lower species of animals, such as frogs, using undifferentiated cells, but never using adult, differentiated cells. ${ }^{32}$ Indeed, in October 1993, scientists at George Washington University Hospital in Washington, D.C., successfully cloned a human by splitting tiny two- to eight-

29. There is another form of asexual procreation known as parthenogenesis, or "virgin birth." See LAURENCE E. KarP, GENETIC ENGINEERING: THREAT OR PROMISE? 185 (1976); GEORGE P. SMITH, GENETICS, ETHICS AND THE LAW 105 (1981). Parthenogenesis may occur spontaneously when the egg of a female spontaneously duplicates its DNA and begins dividing as though it had been fertilized by sperm. KARP, supra at 188-90. This phenomenon has been observed in various species, including drone bees, marine invertebrates, poultry, mice, and golden hamsters. Id. at 189-90. Some scientists have speculated that parthenogenetic birth could theoretically account for one out of every one or two million humans. Id. at 190-91.

Because parthenogenesis involves duplication-albeit spontaneous-of DNA, the resulting offspring is necessarily female and not an exact genetic duplicate of its mother. $I d$. at 185 . Scientists do not yet know what causes parthenogenesis to occur.

30. See Gina Kolata, A New Creation: Eager to Emulate Cloning Feat, a Team Looks to Cows, N.Y. TIMES, Mar. 3, 1997, at B8; NBAC REPORT, supra note 8, at 1 . The same British firm that cloned Dolly, PPL Therapeutics, also recently announced that its scientists in Blacksburg, Virginia, had successfully employed nuclear transfer cloning techniques on the adult differentiated cells of a pig. See Marjorie Miller, Five Pigs Cloned: Transplants to Humans Touted, L.A. TimES, Mar. 15, 2000, at Al. The resulting piglets were named Millie, Christa, Alexis, Carrell, and Dotcom. Id.

31. See Biotechnology and the Ethics of Cloning: How Far Should We Go?, Hearing Before the Subcomm. on Technology of the House Comm. on Science, 105th Cong., Ist Sess. 14 (1997) (statement of Cairol E. Rexroad, Jr., Supervisory Research Physiologist, Agriculture Research Service, Gene Evaluation and Mapping Laboratory, Livestock and Poultry Sciences Institute, United States Dept. of Agriculture, Beltsville Md.); see also NBAC REPORT, supra note 8, at 15.

32. See Robert Briggs \& Thomas King, Transplantation of Living Nuclei from Blastula Cells into Enucleated Frogs' Eggs, 38 PROC. NAT'L ACAD. SCIENCES 455 (1952); NBAC REPORT, supra note 8, at 15-18. But see Genetic Engineering: Evolution of a Technological Issue: Report to the Subcomm. on Science, Research \& Development of the House Comm. on Science \& Astronautics, 92d Cong., 2d Sess. 45 (1972) (stating that clawed toad cloning occurred in 1961); Michael Specter \& Gina Kolata, A New Creation: The Path to Cloning-A Special Report, N.Y. TIMES, Mar. 3, 1997, at A1 (stating that the first successful cloning of frogs did not occur until the early 1970s). 
celled pre-embryos, some of which grew to the morula (thirty-two cell) stage before being destroyed. ${ }^{33}$

Cloning via embryonic cell separation is, in itself, quite spectacular-a sort of forced replication or "splitting" of undifferentiated embryonic cells to form identical twins, triplets, or an even greater number of duplicates. ${ }^{34}$ But cloning embryonic cells does not hold nearly the potential for good-and evil-that cloning differentiated adult cells does. Think of it this way: if you wanted to clone yourself, older cloning techniques would have required the splitting of your cells while you were still an embryo in your mother's womb. The chief difficulty with this technique, of course, is that one cannot know what one is "getting" because the embryo has not yet been born. The embryo is a unique combination of its mother's and father's DNA; therefore, one cannot precisely predict its unique genetic makeup and hence, its appearance, talents, or other genetic predispositions.

Cloning adult, differentiated cells, by contrast, allows one to select the specific genetic traits manifested by an adult that one wishes to duplicate. ${ }^{35}$ The technique used by the Scottish researchers is commonly referred to as "nuclear transfer" cloning. ${ }^{36}$ It begins with the removal of a cell from an adult donor,

33. See Rebecca Kolberg, Human Embryo Cloning Reported, SCIENCE, Oct. 29, 1993, at 652; Susan Katz Miller \& Gail Vines, Human Clones Split Fertility Experts, NEw SCIENTIST, Oct. 30, 1993, at 7; Gina Kolata, Scientist Clones Human Embryos, and Creates an Ethical Challenge, N.Y. TIMES, Oct. 24, 1993, at Al. Those which developed to the morula stage were split at the two-cell stage. See Kolberg, supra, at 652 . The embryos split at the four-cell stage were able to progress only to the sixteen-cell stage, and the embryos split at the eight-cell stage were able to progress only to the thirty-two cell stage. See id. The embryos which progressed to the thirty-two cell stage were viable enough for implantation into a uterus, but were not so implanted. See id.

IVF often involves embryo-splitting in order to increase the number of available embryos for implantation without necessitating costly, invasive, and painful egg harvesting. The general policy among IVF clinics is to implant all embryos created by splitting at once, in order to avoid the possibility of later-born twins. See Annas, supra note 21, at 253. Gregory Pence, however, suggests that not all IVF clinics adhere to this policy and that later-born twins created by IVF have, in fact, already been born. GREGORY E. PENCE, Who's AFraid OF HUMAN CLONING? 127 (1998).

34. See KARP, supra note 29, at 200-01; John A. Robertson, The Question of Human Cloning, 24 HASTINGS CENTER REP. 6, 6-7 (1994).

35. See Koh Chong Lek, Asexual Cloning Redefines Parenthood, New StRalTS TiMES (Malaysia), Mar. 2, 1997, at 28.

36. In March 2000, PPL Therapeutics scientists announced the successful nuclear transfer cloning of a pig using adult differentiated cells. See Ray Moseley \& Jeremy Manier, Another First in Animal Cloning: Pigs the Scientists, Who Also Created Dolly, Eventually Hope to Modify Animal Organs for Human Transplants, CHI. TRIBUNE, Mar. 15, 2000 , at 3. See also Miller, supra note 30 , at Al. Nuclear transfer cloning was also recently used to clone rhesus monkeys at the Oregon Health Sciences University. The monkeys, however, were cloned from embryonic cells, not adult differentiated cells. See Biotechnology and the Ethics of Cloning: How Far Should We Go? Hearing before the Subcomm. on Technology of the House Comm. on Science, 105th Cong., 1st Sess. 20-21 (1997) (statement of M. Susan Smith, Ph.D., Director, Oregon Regional Primate Research Center, Oregon Health Sciences University). 
perhaps a cell scraped from the hand or the tongue or, as in the case of Dolly the sheep, the udder. ${ }^{37}$ An egg would then be harvested from a female. The DNA in the egg's nucleus is removed by a small, vacuum-like apparatus known as a pipette. ${ }^{38}$ This stage of nucleus removal is known as enucleation. ${ }^{39}$ Once the egg has been enucleated, the donor's cell (containing, of course, the desirable DNA) is carefully selected and placed next to the empty, enucleated egg. ${ }^{40}$ A small electric current is then applied to the enucleated egg and donor cells. This process fuses the egg and cells together, leaving the donor cells, and hence, new DNA, inside the egg, which has now been re-nucleated. ${ }^{4 !}$

These first two stages of enucleation and re-nucleation are, in a technological sense, not all that difficult or remarkable. Merely substituting the original DNA in an egg with more desirable DNA does not, ipso facto, yield life. Moreover, uniting the re-nucleated egg with sperm would not prove beneficial from a genetic engineering standpoint, since the introduction of the sperm would yield the usual unpredictable genetic progeny. The resulting offspring, in other words, would be a genetic mixture of the DNA of the sperm and the egg, and scientists would no more know ahead of time what they are "getting" in a genetic sense than they do with any other type of selective breeding.

The question for scientists, therefore, became how to convince the renucleated egg to begin the process of cell division (and hence, life) without sperm. Or, stated another way: What could serve as a "sperm substitute" to provide the spark of life? The answer, it turned out, is electricity. Specifically, the answer is a combination of cell starvation and a mild electric current: the starvation of the cell "tricks" it into a form of hibernation, and the electric current then convinces the cell to begin dividing as though it had been united with a sperm. ${ }^{42}$ Once the dividing cell reaches a viable size, it is implanted into the uterus of a female, ${ }^{43}$ who then carries the fetus to term in the usual way. The resulting child ("clonant") is an exact genetic duplicate of the DNA donor. ${ }^{44}$

37. NBAC REPORT, supra note 8, at 22 .

38. See id. at 19, Figure 4.

39. See id.

40. See id.

41. See id.

42. See NBAC REPORT, supra note 8, at 20-22; LEE M. SILVER, REMAKING EdEN: Cloning AND BEYOND IN A BRAVE NEW WORLd 99-100 (1997); Joan Stephenson, Threatened Bans on Human Cloning Research Could Hamper Advances, 277 JAMA 1023, 1025 (1997).

43. The uterus which is used to bring the clonant to term may be-as in the case of Dolly - that of a surrogate mother who has no genetic link to the offspring. It is, however, conceivable that the cloned zygote could be implanted into the female donor's womb; thus, the female who gave birth could be the biological "mother" of the clonant. If the donor is male, of course, the use of a surrogate mother or artificial womb would be necessary.

44. To say that the resulting clonant is an "exact" genetic duplicate of the donor is a bit of an overstatement, since the individual or animal which donates the enucleated egg will contribute a small amount of genetic material from the egg's mitochondria. See NBAC REPORT, supra note 8, at 17, 20; Stephenson, supra note 42, at 1023; see also R.C. 
Babies conceived by cloning thus come into the world in the usual way. They must be implanted into the womb of a human surrogate mother, ${ }^{45}$ who then carries the embryo through a normal gestation period and gives birth in the normal way. Contrary to the popular cultural perception, ${ }^{46}$ there are no "instant adults" possible with cloning, and the cultural and social experiences of the clonant would likely be very different from those of the DNA donor. ${ }^{47}$ If Michael Jordan, for example, wanted to clone himself, he could do so, but the clonant would be born as a baby who would have to be raised, trained, and educated as any other child. Michael Jordan II would have his own life experiences-friends, successes and failures, historical perspective on the world, inter alia-all of which would combine to form an adult who may or may not be a great basketball player. ${ }^{48}$

Somatic cell nuclear transfer cloning thus allows scientists to know, ahead of time, what they are "getting," genetically speaking. If, for example, you cloned yourself from an adult, differentiated cell, you would be assured that the child ultimately born would have the same genetic makeup that you have. ${ }^{49}$ Nuclear transfer cloning thus holds much more promise for selective breeding because it permits scientists to clone only those fully formed adult animals or

Lewontin, The Confusion over Cloning, THE N.Y. REV. OF BOOKs, Oct. 23, 1997, at 18 n.2. Mitochondrial genes account for only approximately 60 out of 100,000 human genes and are believed to be responsible for the specification of enzyme proteins. See id. The small number of genes present in mitochondria are not believed to affect appearance or personality, but may, if defective, result in certain types of genetic disorders. See id.; see also NBAC REPORT, supra note 8, at 17, 20.

45. Artificial wombs are not yet feasible, but a team of Japanese researchers has succeeded in sustaining goat fetuses outside the womb for up to three weeks in an extrauterine fetal incubation ("EUFI") device. See Perri Klass, Behind Closed Doors: The Artificial Womb Is Born, N.Y. TIMEs, Sept. 26, 1996, at 117; Artificial Womb Can Sustain Goat Fetus for up to 3 Weeks, CHI. TRIBUNE, July 20, 1997, at C8. The major impediment to artificial wombs appears to be the inability to develop an appropriate sterile, highly oxygenated fluid that would allow the developing embryo to breathe. See JEREMY RIFKIN, THE BIOTECH CENTURY: HARNESSING THE GENE AND REMAKING THE WORLD 30 (1998).

46. Movies tend to exacerbate the "instant adults" image of cloning. See, e.g., MULTIPLICITY (Columbia Pictures, 1996) (portraying a man, played by Michael Keaton, who underwent a surgical procedure and emerged with an adult duplicate).

47. Again, popular culture has led us to view cloning as a method not only of genetic duplication but also of duplication of the donor's personality and memory. See, e.g., SLEEPER (United Artists, 1973) (starring Woody Allen as an individual, cloned from another person's nose, who possesses all of the idiosyncratic personality characteristics and memory of the person who donated the nose).

48. Despite this very real limitation on genetic contribution to individuality, the popular perception is that a clonant of Michael Jordan would, in fact, become a great basketball player. See Art Buchwald, The More the Scarier, WASH. POST, Mar. 6, 1997, at B1.

49. This is not to suggest, of course, that the clonant would have the same personality characteristics as the donor. In addition, there is some evidence that a child produced by nuclear transfer cloning would not be $100 \%$ genetically identical to the donor due to the presence of mitochondrial DNA from the enucleated egg. See NBAC REPORT, supra note 8 , at 17,22 . Mitochondrial DNA is not believed to affect appearance or personality, but it may affect the clonant's disposition towards certain diseases. See id. 
plants that possess certain desirable characteristics, such as the ability to produce more milk, resist disease, or bloom larger, more colorful flowers.

Most Americans would not likely find the benefits of selective breeding relevant in the context of cloning human beings. ${ }^{50}$ Human cloning, however, offers benefits beyond simple eugenics. The very idea that adult differentiated cells could be "reprogrammed" to enable them to begin regeneration means that cloned human cells could be cultivated and then "shut off" or "de-programmed" at a critical point of differentiation, at which point these burgeoning skin, bone marrow, liver, kidney, nerve, brain, or other cells could be replicated and allowed to grow into whole organs suitable for transplantation without the risk of rejection because they would be an exact genetic match to the donor. ${ }^{51}$

Moreover, cloning could offer infertile couples certain advantages that are not available with existing reproductive technologies. For example, couples who use IVF ${ }^{52}$ gamete intrafallopian transfer ("GIFT"), ${ }^{53}$ or zygote intrafallopian transfer ("ZIFT") ${ }^{54}$ might opt to clone the embryos created by the IVF, GIFT, or ZIFT process in order to avoid the necessity of future invasive, painful, and expensive egg retrievals from the mother. ${ }^{55}$ Likewise, infertile couples may opt to forego existing artificial reproductive technologies ("ARTs") in favor of cloning because of the inherent risks involved in using donated gametes-sperm or eggsfrom an unknown donor. Cloning would not only allow infertile couples to avoid this physiological risk but would offer a psychological benefit as well, since the

50. Indeed, the polls taken after the news of Dolly uniformly show that the vast majority of Americans are opposed to human cloning. See, e.g., Meredith Wadman, Politicians Accused of "Shooting from the Hip" on Human Cloning, NATURE, Mar. 13, 1997, at 97 (revealing that an ABC News Nightline poll found $87 \%$ of respondents believed human cloning should be banned, and $82 \%$ believed human cloning to be morally wrong).

51. See Stephenson, supra note 42, at 1025; see also Hearing of the Subcomm. on Public Health \& Safety of the Senate Comm. on Labor \& Human Resources, Mar. 12, 1997 (testimony of Harold Varmus, M.D., Director of the National Institutes for Health).

52. IVF is accomplished by removing an egg, combining it with sperm, and, post-fertilization, implanting the embryo into the woman's uterus. See Consumer Protection Issues Involving in Vitro Fertilization Clinics, Hearing Before the Subcomm. on Regulation, Business Opportunities, and Energy of the House Comm. on Small Business, $101 \mathrm{st}$ Cong., 1st Sess. 82 (1989) (providing a glossary of terms provided by the American Fertility Society).

53. GIFT is similar to IVF in that it involves the removal of an egg and combining it with sperm. The chief difference, however, is that with GIFT, the egg and sperm are immediately injected back into the woman's fallopian tubes, and fertilization (if it occurs), occurs inside the fallopian tubes, not in a petri dish. See id.

54. ZIFT differs from GIFT in that fertilization takes place outside the body, and the fertilized egg is then injected into the fallopian tubes. See 1995 ASSISTED REPROdUCTIVE TECHNOLOGY SUCCESS RATES: NAT'L SUMmaRY AND FERTILITY CLINIC REPORTS (visited Oct. 3, 2000) <http://www.cdc.gov/nccdphp/drh/art/htm>.

55. See John A. Robertson, Ethics \& Theology: A Continuation of the National Discussion on Human Cloning, Testimony Before the Subcomm. on Public Health \& Safety, Senate Comm. on Labor \& Human Resources, FEDERAL NEwS SERVICE, June 17, 1997. 
parents of a child created by cloning would be assured that their child's biological link is undiluted by the genes of an individual outside the marriage or relationship.

Along these lines, a correlative use of human cloning-albeit perhaps more controversial-would be the creation of genetically related children for homosexual couples. ${ }^{56}$ Since homosexual couples wishing to have genetically related children currently must resort to the use of donated gametes, existing ARTs provide neither the psychological nor the physical benefits that would derive from cloning. Another rational basis for choosing cloning over coitus or existing ARTs would be to avoid genetic diseases such as sickle cell anemia, Tay Sachs, Down's Syndrome, or Huntington's Disease. ${ }^{57}$ If, for example, a woman has a genetic predisposition towards such genetic disease, she could alleviate or lessen the risk that her child will develop the disease by cloning her husband, another healthy family member, an existing healthy child, or perhaps even a third party.

Thus, despite the vehement rhetoric of cloning opponents who assert that cloning could serve no purpose other than an "ego trip" or the furtherance of other nefarious motives, ${ }^{59}$ there are rational reasons why cloning could provide an attractive reproductive alternative. Moreover, although nuclear transfer cloning has not yet been successfully accomplished with humans, most people seem to assume that it is only a matter of time before this science-fiction fantasy becomes reality. ${ }^{60}$ When the time comes, will our legal system be ready? What should we, as lawyers and citizens and lawmakers, be doing today to prepare for the inevitable? What legal limits do we face?

56. The issue as to whether procreative liberty would encompass the use of ARTs by non-married individuals is discussed infra Part IV.B.

57. See NBAC REPORT, supra note 8, at 77.

58. See Richard Louv, Making Babies the New Way: It's Imperfect, SAN DIEGO UNION-TRIB., Sept. 19, 1998, at E1 ("Cloning could make possible the ultimate ego trip: I'll bet I can do a better job of raising me than my parents did."); David S. Swift, Never, Ever Repeat Yourself; But I Repeat Myself, THE PLAIN DEALER, Feb. 8, 1998, at 6 ("Although its opponents won't admit it, their fundamental objection to human cloning is this: to clone your own DNA is the ultimate ego trip.").

59. See, e.g., Leon R. Kass, The Wisdom of Repugnance: Why We Should Ban the Cloning of Humans, 32 VAL. U. L. REV. 679, 682-83 (1998):

Through cloning, we can work our wants and wills on the very identity of our children, exercising control as never before. Thanks to modern notions of individualism and the rate of cultural change, we see ourselves not as linked to ancestors and defined by traditions, but as projects for our own self-creation, not only as self-made men but also man-made selves; and self-cloning is simply an extension of such rootless and narcissistic self re-creation.

Id.

60. See generally CLONING HUMAN BEINGS: REPORT AND RECOMMENDATIONS OF THE NATIONAL BIOETHICS ADVISORY COMM'N (1997). 


\section{Protections for Clones Under Current LAW}

At the present time, American law handles plant and animal clonants as "property" subjected to ordinary patent and contract laws. ${ }^{61}$ But what of humans created by cloning? Would they also be considered "property" to be bought, sold, or otherwise controlled by their creators? No, current law would provide numerous protections to individuals conceived by cloning, negating the possibility of the most commonly feared science-fiction abuses.

\section{A. "Spare" Organ Farming}

As an initial matter, a baby created by cloning who is born (i.e., not aborted or miscarried) would be as fully a "person" under current law as a baby created by sexual intercourse or ARTs such as IVF or artificial insemination. ${ }^{62}$ Such children would be fully "human," containing a full complement of human genes the same as any other human; that their genes would be a combination of the parents of the DNA donor would not alter their humanness. ${ }^{63}$ Individuals conceived by cloning would not differ biologically from individuals conceived by coitus or other ARTs. ${ }^{64}$ Although a child created by cloning would share his/her genes with another, this has never created a legal obstacle to distinct "personhood," as evidenced by identical twins and other multiple births. Thus, a child created by cloning would not be considered "the same person" as his/her DNA donor, but would be legally entitled to recognition as a distinct person, as are twins. ${ }^{65}$ Individuals conceived by cloning, therefore, would not legally be considered "property" but would enjoy the full protection of laws protecting all

61. See, e.g., Chiron Corp. v. Abbott Labs., 902 F. Supp. 1103 (N.D. Cal. 1995); Regents of the Univ. of Calif. v. Eli Lilly \& Co., 1995 U.S. Dist. LEXIS 19003 (S.D. Ind. 1995); New England Med. Center Hosps., Inc. v. Peprotech, Inc., 1993 U.S. Dist. LEXIS 20256 (D.N.J. 1993).

62. For analysis of the legal status of unborn embryos created by cloning, see discussion infra Part III.C.

63. Thus, for example, if Betty clones herself, the resulting child would possess a combination of genes inherited from Betty's parents.

64. As such, individuals conceived by cloning would be qualitatively (biologically) different from such science fiction creatures as human-animal hybrids (chimeras). With regard to human-computer/mechanical hybrids (cyborgs), the present state of knowledge of this term assumes that the person is dependent upon mechanical means for one or more of his vital physiological functions. See WEBSTER'S NEW ColLEGIATE DictionarY 280 (1981). Thus, cyborgs would possess a full complement of human genes but merely use certain mechanical means by which to carry out certain functions (e.g., the use of a "bionic" arm). An interesting ethical and legal question may arise, however, if the vital function achieved by mechanical means is the processing of thoughts (i.e., the use of a computerized brain). Such cyborgs would still presumably possess a full complement of human genes, but many individuals would intuitively consider such cyborgs less (or more?) than human. Whether or to what extent such individuals should be considered legally "human," while fascinating, is well beyond the scope of this Article.

65. In fact, because twins and other multiple identical births share mitochondrial genes, they are, in fact, more genetically "identical" than a clone is to his/her DNA donor. See Lewontin, supra note 44, at 18. 
persons. ${ }^{66}$ Indeed, any other conclusion would require that humankind begin drawing dangerous and dubious distinctions amongst different "kinds" or "types" of human beings based upon how they were conceived ${ }^{67}$-distinctions that fortunately have not been drawn despite great leaps in reproductive science. ${ }^{68}$

One of the most common fears associated with human cloning is that individuals conceived by cloning would be forced to serve as organ donors. ${ }^{69}$

66. Indeed, if our laws treated individuals conceived by cloning differently from individuals conceived in other ways, the Equal Protection Clause could be implicated. If individuals conceived by cloning were considered a "discrete and insular minority" within the meaning of Carolene Products' famous footnote four, any law which treated such individuals differently from the rest of the population could be subjected to strict scrutiny. United States v. Carolene Products Co., 304 U.S. 144, 153 n.4 (1938) ("[P]rejudice against discrete and insular minorities may be a special condition, which tends seriously to curtail the operation of those political processes ordinarily to be relied upon to protect minorities, and which may call for a correspondingly more searching judicial inquiry."). Because individuals conceived by cloning possess "obvious, immutable, or distinguishing characteristics that define them as a discrete group," Lyng v. Castillo, 477 U.S. 635, 638 (1986), strict scrutiny would seem to be appropriate in this context. For a detailed discussion of the possible equal protection issues raised by a ban on human cloning, see infra Part IV.C.

67. Francis Pizzulli seems to fall into the trap of classifying humans created by cloning as somehow subhuman when she states, "Implicit in the prohibition of clonal humans is the rationale that certain types of humans ought not to exist, either because they have inalienable rights to nonexistence or because their presence would erode important social values." Pizzulli, supra note 21 , at 493 . Laurence Tribe has noted this danger in the context of human cloning, stating, "There are few evils as grave as that of creating a caste system, one in which an entire category of persons, while perhaps not labeled untouchable, is marginalized as not fully human." Laurence H. Tribe, Second Thoughts on Cloning, N.Y. TIMES, Dec. 5, 1997, at A31; see also Laurence Tribe, On Not Banning Cloning for the Wrong Reasons, in Clones AND Clones: FACTS AND FANTASIES ABOUT HUMAN Cloning 221, 229 (Martha C. Nussbaum \& Cass R. Sunstein eds., 1998) [hereinafter Wrong Reasons]:

That cost, to the degree any ban on using a given mode of baby making is bound to be evaded, is the very considerable one of creating a class of potential outcasts-persons whose very existence the society has chosen, through its legal system, to label as a misfortune, and, in essence, to condemn.

Id.

68. No one would seriously argue, for example, that children conceived by ARTs such as IVF are not persons entitled to the full protection of the law.

69. See, e.g., Fear of Cloning, THE ECONOMIST, Jan. 17, 1998, at 18 ("'[I]t is conceivable that some new monster will create and imprison his cloned offspring against the day when he needs a genetically compliant spare heart or kidney, or for some other dark purpose."); James P. Pinkerton, Civil Rights for Clones or Against Clones?, NewSDAY, Dec. 11, 1997, at A51 ("What would Bill Gates do if he needed a kidney? Would the Microsoft mogul put himself on an organ waiting list like everyone else? He might be tempted ... [to] go all the way and order up a clone of himself, with the guarantee of tissue compatibility."); see also Lori B. Andrews, Is There a Right to Clone? Constitutional Challenges to Bans on Human Cloning, 11 HARv. J.L. \& TECH. 643, 668 (1998) (suggesting that the use of 
Thus, for example, people worry that a person dying of heart disease would clone herself for the purpose of harvesting the "spare" organ from the clone. This fear is, of course, legally unfounded, as current laws prohibiting battery ${ }^{70}$ and murder ${ }^{71}$ clearly prevent the non-consensual touching of another.

Under current law, competent individuals are free to donate organs or tissue (or to make any other personal health care decision), provided, of course, that the decision is an informed one. ${ }^{72}$ Competent individuals unwilling to donate organs or tissue cannot, pursuant to common law, be forced to make such donations. ${ }^{73}$ Moreover, current law permits medical procedures to be performed on individuals who are not competent to consent to such procedures, e.g., the mentally retarded and minors, if the medical procedure sought to be performed is, pursuant to clear and convincing evidence, in the individual's "best interests."74 This "best interests" standard extends to organ donation situations, with courts generally authorizing the removal of organs from incompetent persons incapable of providing consent if the removal of the organ would be in their "best

clonants as "spare parts" for organ transplantation may violate the clonant's Thirteenth Amendment rights).

70. See, e.g., FLA. STAT. $\S 784.03$ (1998) (defining battery as "[a]ctually and intentionally touch [ing] or strik[ing] another person against the will of the other."); Mahaise v. United States, 722 A.2d 29, 30 (D.C. Ct. App. 1998) ("A battery is any unconsented touching of another person.").

71. See, e.g., MICH. COMP. LAws $\$ 750.316$ (1998) (defining first-degree murder as "any [] willful, deliberate, and premeditated killing."); People v. Carter, 387.Mich. 397, 417 (1972) (defining murder to include "all unlawful killing done with malice aforethought.").

72. See, e.g., Cobbs v. Grant, 502 P.2d 1, 9 (Cal. 1972) (dealing with the issue of informed consent with regard to medical procedures). The Supreme Court has intimated that a competent person may indeed have a constitutionally protected right, under the liberty interest of the Due Process Clause, to refuse unwanted medical treatment, even if such treatment is life-sustaining (e.g., hydration and nutrition). See Cruzan v. Director, Missouri Dep't of Health, 497 U.S. 261, 279 (1990) ("[F]or purposes of this case, we assume that the United States Constitution would grant a competent person a constitutionally protected right to refuse lifesaving hydration and nutrition."); see also id. at 287 (O'Connor, J., concurring) ("I agree that a protected liberty interest in refusing unwanted medical treatment may be inferred from our prior decisions, and that the refusal of artificially delivered food and water is encompassed within that liberty interest.") (citation omitted); Bartling v. Superior Court, 163 Cal. App. 3d 186, 195 (Cal. Ct. App. 1984) ("The right of a competent adult to refuse medical treatment is a constitutionally guaranteed right which must not be abridged.").

73. See, e.g., McFall v. Shimp, 10 Pa.D. \& C.3d 90 (1978) (denying petition to order unwilling cousin to submit to compatible bone marrow donation).

74. See, e.g., In the Matter of A.M.P., 708 N.E.2d 1235, 1239 (Ill. Ct. App. 1999) (holding that court could order 16-year-old psychotic and noncommunicative woman to undergo electroconvulsive therapy if such treatment would be in her best interests); In the Matter of Grady, 426 A.2d 467, 475, 481-83 (N.J. 1982) (holding that court has parens patriae authority to order sterilization of 19-year-old Down's Syndrome woman if sterilization would be in her best interests). 
interests." ${ }^{275}$ Specifically, the cases authorizing removal of the organ in question uniformly find that the donor of the organ would experience a net benefit from the donation, based upon the donor's close familial relationship to the organ recipient and the psychological advantages of having such a close family member live rather than die. $^{76}$

Under current law, therefore, individuals conceived by cloning (or any other method of procreation, for that matter): (1) could donate organs or tissue if they were competent and provided their informed consent to the procedure; or (2) could be compelled by the court to donate their organs or tissue if they were legally incompetent to make their own informed decision, but only if such donation would be in their own "best interests." Thus, if a woman clones herself in order to create a baby who can serve as a source of bone marrow, current law would allow the removal of marrow if it could be shown, by clear and convincing evidence, to be in the "best interest" of the baby. This heavy burden, moreover, successfully could be borne if the court is convinced that the baby would be "better off" giving up his/her bone marrow rather than by retaining the marrow and having his mother die. If, on the other hand, the woman wanted to clone herself in order to create a baby who could serve as a source for a new heart, current law would not allow such donation, as donation of a life-sustaining organ would clearly not be in the "best interests" of the baby.

The inquiry does not end here. Although current law restricts involuntary organ donation to those situations in which the donation is in the donor's "best interests," could state legislatures effectively nullify case law by enacting specific statutes authorizing organ harvesting from individuals conceived by cloning? No, any law which sanctioned involuntary organ harvesting would likely be held unconstitutional under the Due Process Clauses of the Fifth and/or Fourteenth

75. See, e.g., Curran v. Bosze, 566 N.E.2d 1319, 1331, 1343-44 (Ill. 1990) (disallowing petition to have three-and-a-half-year-old twins tested for compatibility for kidney transplant to 12-year-old half-brother); Strunk v. Strunk, 445 S.W.2d 145 (Ky. 1969) (allowing removal of kidney from 27-year-old mentally retarded man for transplantation into his 28 -year-old brother); Little v. Little, 576 S.W.2d 493, 498-500 (Tex. App. 1979) (allowing removal of kidney from 14-year-old mentally incompetent daughter for transplantation into her younger brother); see also Charles $\mathrm{H}$. Baron, et. al., Live Organ and Tissue Transplants from Minor Donors in Massachusetts, 55 B.U. L. REV. 159, 178-81 (1975) (describing application of the "best interests test" used in such situations).

76. See Strunk, 445 S.W.2d at 146; Little, 576 S.W.2d at 498; see also Hart v. Brown, 289 A.2d 386, 389 (Conn. Super. Ct. 1972) (allowing removal of kidney from seven-year-old girl for transplantation into her identical twin on grounds, inter alia, that the evidence indicated that a successful transplant "would be of immense benefit to the donor in that the donor would be better off in a family that was happy than in a family that was distressed and in that it would be a very great loss to the donor if the donee were to die from her illness."); Curran, 566 N.E.2d at 1343-44 (disallowing transplantation on grounds that threee-and-a-half-year-old potential donors would not benefit psychologically from donation to 12-year-old half-brother with whom they were not raised and did not know as family). 
Amendments. ${ }^{77}$ After all, any law that required a competent adult to sacrifice his tissue or organs-against his will-for the benefit of another would surely deprive that person of "life" or "property" without due process of law. ${ }^{78}$ Moreover, such barbaric activity would also run afoul of the Fourth Amendment's prohibition against unreasonable searches and seizures. ${ }^{79}$

Several Supreme Court cases illustrate this point. In Rochin $v$. California ${ }^{80}$ the Supreme Court was asked to consider the constitutionality of a conviction which rested upon evidence consisting of two capsules of morphine. After police arrested the defendant, the officers unsuccessfully attempted to extract the capsules from his mouth by force. ${ }^{81}$ The police then took the defendant to the hospital, where a doctor pumped the defendant's stomach against his will and removed the capsules. ${ }^{82}$ The Court concluded that pumping the accused's stomach in an attempt to obtain evidence "shock[ed] the conscience" and therefore violated the Due Process Clause. ${ }^{83}$ The Court found the action barbaric, characterizing the forcible opening of the accused's mouth and subsequent stomach pumping to be "methods too close to the rack and the screw to permit of constitutional differentiation." 84

Subsequently, in Schmerber v. California, ${ }^{85}$ the Court was asked to consider the constitutionality of the withdrawal of a blood sample in order to test the blood alcohol level of an individual involved in an automobile accident. ${ }^{86}$ The Court dismissed the defendant's due process claim, reasoning that the withdrawal of blood "by a physician in a simple, medically acceptable manner in a hospital environment ${ }^{987}$ did not shock the conscience as required by Rochin. ${ }^{88}$ Moreover, the Court dismissed the defendant's claim of a Fourth Amendment violation, concluding that "[e]xtraction of blood samples for testing ... [is] commonplace in these days of periodic physical examinations and experience with them teaches that the quantity of blood extracted is minimal, and that for most people the procedure involves virtually no risk, trauma, or pain." 89 Such a minor, risk-free, painless extraction of bodily fluid was, therefore, permitted under the Fourth Amendment, but the Court made it clear that their decision "in no way indicates

77. See cases cited infra notes 80-107.

78. See, e.g., Rochin v. California, 342 U.S. 165 (1952) (holding that stomach pumping by police to obtain evidence of crime offended due process).

79. "The right of the people to be secure in their persons, houses, papers, and effects, against unreasonable searches and seizures, shall not be violated ...." U.S. CoNST. amend. IV.

80. 342 U.S. 165 (1952).

81. See id. at 166.

82. See id.

83. Id. at 172.

84. Id.

85. 384 U.S. 757 (1966).

86. See id. at 758-59.

87. Id. at 759 .

88. See id. at 760.

89. Id. at 771 . 
that [the Constitution] permits more substantial intrusions, or intrusions under other conditions." 90

In 1985, the Court was again asked to determine the constitutionality of a state-ordered bodily intrusion. ${ }^{91}$ Specifically, in Winston $v$. Lee $^{92}$ the Commonwealth of Virginia moved the state trial court for an order directing the defendant, a robbery suspect, to undergo forcible surgery to remove a bullet lodged in his collarbone. ${ }^{93}$ The state trial judge granted the motion, and the defendant sought injunctive relief in the federal courts on Fourth Amendment grounds. ${ }^{94}$ The Supreme Court held that the proposed surgery violated the defendant's Fourth Amendment rights, adopting a "case-by-case approach" for analyzing the reasonableness of surgical intrusions of an accused. ${ }^{95}$

Specifically, the Court stated that its earlier decision in Schmerber required a balancing test for bodily intrusions "in which the individual's interest in privacy and security are weighed against society's interests in conducting the procedure." ${ }^{396}$ In applying this balancing test to the case at bar, the Court concluded that the Commonwealth had not demonstrated a "compelling need" for the removal of the bullet, as there was "substantial additional evidence" that the defendant was the robber. ${ }^{97}$ Balanced against this weak need for the surgery, the Court characterized the proposed surgery as a "severe" intrusion on the defendant's privacy, noting that the minimal risks of nerve damage and/or death ${ }^{98}$ "militates against finding the operation to be "reasonable."'99

Taking all of these cases together, several rules emerge. First, pursuant to Rochin, the removal of items from one's body will violate the Due Process Clause if it "shocks the conscience." 100 Second, minor bodily intrusions with a minimal risk of harm will be tolerated by both the Due Process Clause and the Fourth Amendment pursuant to Schmerber, provided there is a compelling need for the intrusion. Third, without a compelling need for the bodily intrusion, as in Winston, the intrusion will not be constitutionally permissible, even if the risk of harm is concededly minimal. Finally, some lower federal courts have expressed their belief that the Fourth Amendment balancing test provided for in Schmerber was intended to replace the substantive due process analysis of Rochin after the incorporation of the exclusionary rule to the states. ${ }^{101}$ The Court itself, however,

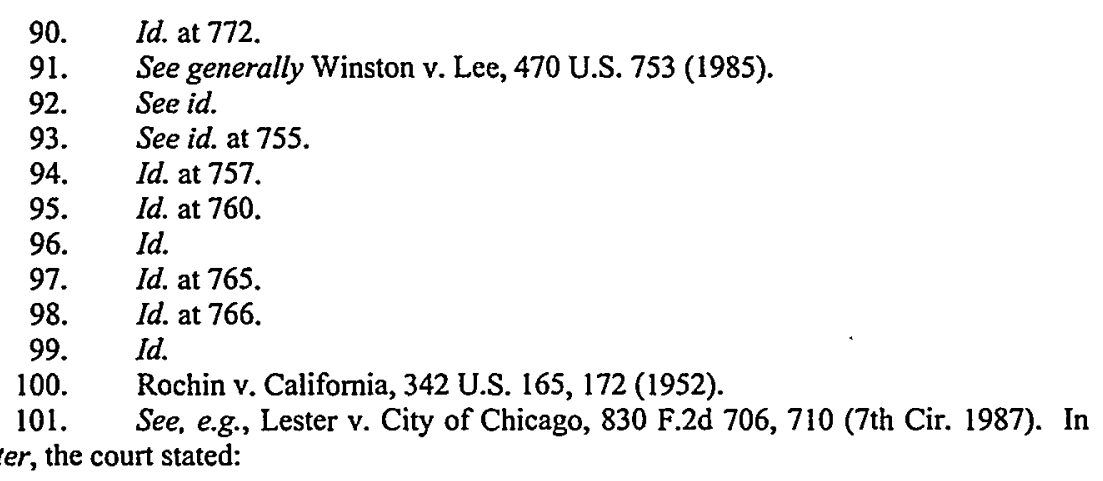


has never overruled Rochin nor stated that the substantive due process analysis is, in fact, moribund.

In the context of a hypothetical statute authorizing the removal of tissue or organs from individuals conceived by cloning, it seems clear that such a statute would be declared unconstitutional. The forced removal of life-sustaining organs to save another would certainly "shock the conscience" and thus violate due process. Moreover, taking the life of one person in order to save another person has never before been considered a "compelling need" and thus would be unlikely to survive the Fourth Amendment balancing test of Schmerber. ${ }^{102}$ The removal of a blood sample upheld in Schmerber involved essentially no pain or risk of bodily harm to the defendant, and the Court made it clear that more substantial bodily intrusions, e.g., removal of a life-sustaining organ, would be scrutinized much more closely. ${ }^{103}$ More invasive surgical intrusions, such as that involved in Winston, are unlikely to survive the Schmerber balancing test because the costs of the intrusion-increased threat to privacy and the higher degree of harm-will weigh as much, if not more, than the need to remove the organ. ${ }^{104}$

But what of the forcible removal of tissues or organs that are not life sustaining? Would such removal violate due process or the.Fourth Amendment? This is perhaps a closer constitutional question. The strongest case for constitutional invalidation of such action is the Due Process Clause, since forcible removal, even of non-life sustaining tissue or organs, would still shock the conscience under the rule of Rochin. ${ }^{105}$ After all, if the forcible pumping of one's stomach, which is a relatively quick and risk-free procedure, shocks the conscience, one can reasonably assume that the forcible removal of a non-life sustaining organ such as a kidney or eye would likewise shock the conscience. But what of the Fourth Amendment? Schmerber and Winston make it clear that a balancing test would be required and that even relatively minor surgical intrusions would not be permitted absent a compelling need.

Suppose, for example, that an individual has kidney disease and will die within a year without a transplant. Further suppose that this individual is on a waiting list to receive a kidney, but the physicians are not hopeful that a

\footnotetext{
At the time the Court decided Rochin, the Court had not yet held that the Fourth Amendment's exclusionary rule applied to the states. Thus, the Rochin Court used the "shocks the conscience" standard to exclude the evidence obtained by pumping the suspect's stomach. Subsequent to Rochin, the Supreme Court reversed itself, and applied the Fourth Amendment exclusionary rule to the states. Consequently, the Court has not relied on the Rochin "shocks the conscience" standard but has instead applied a Fourth Amendment reasonableness analysis in cases that, like Rochin, involved highly intrusive searches or seizures.

102. See Schmerber v. California, 384 U.S. 757, 771-72 (1966); see also

103. See supra notes $85-90$ and accompanying text.

104. See Winston, 470 U.S. at 766.

105. See Rochin, 342 U.S. at 172.
}

Id. (citations omitted). Winston, 470 U.S. at 765. 
compatible kidney will be found in time. If the individual then successfully clones himself, could one of the child's kidneys be forcibly removed, assuming a specific state statute authorizes the removal to save the man's life?

The salient question, in the context of a Fourth Amendment analysis of the validity of the statute, is whether saving the man's life is a sufficiently "compelling need" to justify the bodily intrusion of the child. If the hypothetical statute authorized the forcible removal of non-life sustaining organs or tissues under such circumstances, a court would have to consider whether the benefit flowing from the bodily intrusion-here, a societal benefit of increasing the availability of transplants and the individualized benefit of saving the man's lifewould outweigh the costs of the bodily intrusion that would rob the child of a kidney and expose the child to health risks that are moderate to severe.

The outcome of the Fourth Amendment balancing test, therefore, may hinge upon the degree of harm that reasonably would be expected to result to the donor (i.e., the child). If the degree of harm to the donor is small, and the benefit to the individual donee and society is large, the Fourth Amendment may well allow the removal of the organ. If, on the other hand, there were any facts to indicate that the degree of harm that would reasonably be expected to result to the donor would be high, the application of the statute to the donor may well violate the donor's Fourth Amendment right to be free from "unreasonable" search and seizure. In other words, where both parties may be significantly harmed, a statutorily sanctioned seizure of the donor's organ or tissue would appear to be "unreasonable" in violation of the Fourth Amendment, since it would be virtually impossible for a court to choose one life over another.

Thus, although the Fourth Amendment question is a closer call in the context of the removal of non-life sustaining tissue or organs, the end result may often be the same: removal would not be constitutionally permissible. Moreover, even assuming arguendo that a court would apply the Schmerber balancing test differently and conclude that the removal of non-life sustaining tissue or organs would not violate the Fourth Amendment, the application of a statute authorizing removal of such non-life sustaining tissue or organs could still be invalid under the Due Process Clause, pursuant to the Rochin "shocks the conscience" test. ${ }^{106}$

It is also important to note that the discussion about the constitutional validity of a statute authorizing the removal of non-life sustaining tissue or organs is not unique to human cloning. In other words, a statute authorizing the removal of non-life sustaining tissue or organs to save the life of another could be passed right now when human cloning is not yet possible. If such a statute were passed today, the constitutional analysis would be the same. Human cloning, in other words, does not alter the constitutional analysis or make it any more likely that such a statute would be enacted. After all, if legislators have not yet seen fit to pass such a statute (for all the obvious reasons), despite a well-known shortage of

106. Id. 
organs available for transplantation, ${ }^{107}$ then the availability of human cloning would not likely cause legislators to re-think their positions. And even if legislators did rethink their positions and pass a statute authorizing such removal, the statute would likely run afoul of both due process and the Fourth Amendment.

\section{B. Slavery: The Thirteenth Amendment}

Another commonly held fear associated with human cloning is that individuals conceived by cloning could be forced into slave labor, to serve at the whim of the rich and powerful. This fear is also unfounded. Current statutes ${ }^{103}$ and the Thirteenth Amendment ${ }^{109}$ protect all persons (regardless of how they are conceived) from slavery and involuntary servitude. ${ }^{110}$

Interestingly, some have argued that allowing human cloning to take place could violate the Thirteenth Amendment rights of the individuals so conceived. One adherent of this view, Professor Lori Andrews, argues that human cloning "may create a form of "genetic bondage" or impose a "badge of slavery" "11 that would violate the Thirteenth Amendment. ${ }^{112}$ She argues that because cloning would create a later-born genetic twin, the resulting child's "autonomy might be limited where his or her genetic traits and predispositions are already known." 13 The person created by cloning, therefore, may lack the same free will as a person created by sexual procreation and thereby be enslaved in violation of the Thirteenth Amendment. ${ }^{114}$

The Thirteenth Amendment is self-executing to a limited extent; it prohibits slavery and involuntary servitude, whether imposed by the government or a private party, without the necessity of enabling legislation. ${ }^{15}$ More

107. See Arthur L. Caplan, Current Ethical Issues in Organ Procurement and Transplantation, 272 JAMA 1708 (1994) (reporting that as of the end of 1993, there were over 33,000 individuals on the United Network for Organ Sharing waiting list).

108. See 18 U.S.C. $\$ \S 1581-88$ (1994 \& Supp. 1998).

109. The Thirteenth Amendment states in pertinent part, "Neither slavery nor involuntary servitude, except as a punishment for crime whereof the party shall have been duly convicted, shall exist within the United States, or any place subject to their jurisdiction." U.S. CONST. amend. XIII, § 1.

110. See, e.g., United States v. Kozminski, 487 U.S. 931 (1988) (dealing with involuntary servitude).

111. Lori B. Andrews, The Current and Future Legal Status of Cloning, at 65 (paper submitted to the NBAC) [hereinafter Andrews Paper]; accord Andrews, supra note 69 , at 668 .

112. Andrews Paper, supra note 111, at 65.

113. Id.

114. See id.

115. Cf. City of Memphis v. Greene, 451 U.S. 100, 124-25 (1981) ("Pursuant to the authority created by Section 2 of the Thirteenth Amendment, Congress has enacted legislation to abolish both the conditions of involuntary servitude and the "badges and incidents of slavery.' The exercise of that authority is not inconsistent with the view that the Amendment has self-executing force.") (citations omitted); id. at 125-26 (noting that "[i]n Jones, the Court left open the question whether Section 1 of the [Thirteenth] Amendment by its own terms did anything more than abolish slavery. It is also appropriate today to 
importantly, however, Congress may enact legislation to enforce the rights conferred by the Amendment pursuant to the Amendment's Enabling Clause. ${ }^{116}$ Indeed, in the Civil Rights Cases, ${ }^{117}$ the Supreme Court determined that the Enabling Clause of the Thirteenth Amendment ${ }^{118}$ permits Congress to enact laws aimed at eliminating the "badges and incidents of slavery." 19

In the seminal case of Jones $v$. Alfred H. Mayer Co., ${ }^{120}$ the Supreme Court significantly broadened the scope of congressional power under the Amendment's Enabling Clause, holding that laws enacted pursuant to the Clause are valid so long as the practice prohibited by Congress is "rationally" capable of classification as a "badge" or "incident" of slavery. ${ }^{12}$ The question becomes, then, whether human cloning is rationally capable of classification as a badge or incident of slavery. If a federal law banning human cloning is enacted, ${ }^{122}$ the Jones mandate of deference to congressional determinations of a badge or incident of slavery would certainly enhance the likelihood that a cloning ban would be a valid exercise of congressional power under the Enabling Act of the Thirteenth Amendment. In other words, if a court believed it was rational for Congress to consider cloning as tantamount to a badge or incident of slavery, the law should be upheld. ${ }^{123}$

The next question becomes: what is a "badge" or "incident" of slavery? Unfortunately, the precise contours of these terms is far from clear. In the Civil Rights Cases, the Court loosely defined "badges of slavery" as laws that infringe upon "those fundamental rights which appertain to the essence of citizenship."124 The Jones Court subsequently offered some limited guidance:

The Thirteenth Amendment authorizes Congress not only to outlaw all forms of slavery and involuntary servitude but also to eradicate the last vestiges and incidents of a society half slave and half free, by securing to all citizens, of every race and color, "the same right to make and enforce contracts, to sue, to be parties, give evidence, and

leave that question open ... ."); see also Jones v. Alfred H. Mayer Co., 392 U.S. 409, 439 (1968) ("WW]hether or not the [Thirteenth] Amendment itself did any more than that [is] ... a question not involved in this case....").

116. See U.S. CoNST. amend. XIII, $§ 2$.

117. 109 U.S. 3 (1883).

118. The Clause reads: "Congress shall have power to enforce this article by appropriate legislation." U.S. CoNST. amend. XIII, § 2.

119. The Civil Rights Cases, 109 U.S. at 20; accord Jones, 392 U.S. 409, 438-40.

120. 392 U.S. 409 (1968).

121. ' Id. at 439-40 ("Surely Congress has the power under the Thirteenth Amendment rationally to determine what are the badges and the incidents of slavery, and the authority to translate that determination into effective legislation.").

122. I discuss only federal laws here because the Enabling Clause of the Thirteenth Amendment provides only Congress with the power to enact "appropriate legislation" to enforce the Amendment. U.S. CONST. amend. XII, § 2 ("Congress shall have power to enforce this article by appropriate legislation.").

123. See Jones, 392 U.S. at 440-41.

124. The Civil Rights Cases, 109 U.S. at 22. 
to inherit, purchase, lease, sell and convey property, as is enjoyed by white citizens. ${ }^{125}$

Justice Douglas, concurring in Jones, had a broader conceptualization of the badges and incidents of slavery, asserting that the phrase included, inter alia, laws that segregated African Americans from whites in housing, schools, hotels, restaurants, and public facilities, as well as laws that prevented African Americans from voting, serving on juries, marrying whites, joining unions, and entering college. ${ }^{126}$

While there is certainly a difference in scope between the Jones majority's conceptualization of badges and incidents of slavery and the broader conceptualization offered by Justice Douglas, the Justices did agree that the terms encompassed those conditions that impose upon individuals a stamp of inferiority based upon race. ${ }^{127}$ Thus conceptualized, the Thirteenth Amendment ensures to all Americans, regardless of their race, the freedoms enjoyed by whites. Prejudicebased laws or conditions that stamped individuals of a certain race as inferior by restricting or denying them freedoms enjoyed by whites were thus liable to challenge by Congress. ${ }^{128}$ Pursuant to the Thirteenth Amendment's Enabling Clause, Congress has the power to enact civil rights statutes aimed at ensuring that all citizens, regardless of race, may enjoy "those fundamental rights which appertain to the essence of citizenship" such as the making and enforcement of contracts ${ }^{129}$ and the ownership and inheritance of property. ${ }^{130}$ Given this general definition of the badges and incidents of slavery, it is unlikely that a law banning human cloning could be construed as an attempt by Congress to remove a stamp of inferiority based upon race.

It is unlikely that individuals conceived by cloning would constitute a separate "race" as that term is commonly understood. The dictionary defines "race" in numerous ways, none of which appears to apply to individuals conceived by cloning. One definition is a "local geographic or global human population distinguished as a more or less distinct group by genetically transmitted physical characteristics."131 Another definition is a "group of people united or classified

125. 392 U.S. at $443 \&$ n.78 (quoting The Civil Rights Cases, 109 U.S. at 22).

126. See id. at 445-48 (Douglas, J., concurring).

127. See Plessy v. Ferguson, 163 U.S. 537, 551 (1896) (holding that Louisiana law mandating segregation of African Americans from Caucasians in railway cars did not violate the Thirteenth Amendment because it did not "stamp[ the colored race with a badge of inferiority"), overruled by Brown v. Board of Educ. of Topeka, 347 U.S. 483 (1954).

128. See Jones, 392 U.S. at 443, n.78; see also id. at 445-48 (Douglas, J., concurring).

129. 42 U.S.C. $\S 1981$ (a) (1994) ("All persons within the jurisdiction of the United States shall have the same right in every State and Territory to make and enforce contracts....").

130. See 42 U.S.C. $§ 1982$ (1994) ("All citizens of the United States shall have the same right, in every State and Territory, as is enjoyed by white citizens thereof to inherit, purchase, lease, sell, hold, and convey real and personal property.").

13i. THE AMERICAN HeRITAGE Dictionary 1020 ( $2 \mathrm{~d}$ ed. 1985). 
together on the basis of common history, nationality, or geographical distribution: the German race."- 132 Yet another definition is a "genealogical line; lineage. . .."133

Whichever definition one uses to define "race,"134 it seems clear that human beings conceived by cloning would not constitute a separate race. Human beings conceived by cloning would not be "distinguished" by "genetically transmitted physical characteristics," since each would have the genetic makeup of his or her DNA donor. Such individuals would no more constitute a distinct "race" than would their DNA donors. Likewise, humans conceived by cloning would not constitute an ethnic group united or classified together "on the basis of common history, nationality, or geographical distribution," because such individuals would be born into different families, at different times, and in different nations around the world. Finally, humans created by cloning would not constitute a distinct "genealogical line" because each would have different DNA mirroring their individual DNA donors. They would therefore no more constitute a "lineage" than would their DNA donors.

A federal ban on human cloning would do nothing to ensure that individuals created by cloning enjoyed "those fundamental rights which appertain to the essence of citizenship,"135 since it would prevent such individuals from ever being born. Moreover, a federal cloning ban would not prevent discrimination based on prejudicial notions of the inferiority of the "race" of individuals so conceived, but rather fears about the social, moral, and ethical implications of the procedure itself. Indeed, to the extent that there would be any prejudicial notions at all associated with individuals conceived by cloning, it is more likely that the prejudice would manifest itself as a desire to prevent the formation of a superior race rather than a desire to prevent discrimination based upon notions of such individuals' inferiority. ${ }^{136}$

Critics of human cloning might argue that individuals conceived by cloning inherently would be inferior because such individuals would lack the same

132. Id. The Supreme Court concluded that this sort of "ethnic" definition of the term "race" was intended to be included by Congress in the enactment of $\S 1981$. See Saint Francis College v. Al-Khazraji, 481 U.S. 604, 612-13 (1987).

133. THE AMERICAN HERITAGE DICTIONARY 1020 (2d ed. 1985).

134. A full discussion of how to define the term "race" is not necessary in this context and is well beyond the scope of this Article. For a complete discussion of the issue, see Michael Omi \& Harold Winant, Racial Formation, in RACE, CLASS AND GENDER IN THE UNITED STATES 26-33 (Paula Rothenberg ed., 1992).

135. See The Civil Rights Cases, 109 U.S. 3, 22 (1883).

136. See, e.g., Eric A. Posner \& Richard A. Posner, The Demand for Human Cloning, in Clones and Clones: Facts and Fantasies About Human Cloning 233, 238 (Martha C. Nussbaum \& Cass R. Sunstein eds., 1998):

[T] he demand for human cloning is likely to be concentrated in people who have 'good' genes (by which we mean genes that make it more likely that a person will have good physical and mental health, high intelligence, or other prized talents, energy, and physical attractiveness, Id. not necessarily genes that maximize reproductive fitness) .... 
degree of free will as individuals conceived in other ways. The argument would be that because an individual conceived by cloning would have a certain foreknowledge of his life, e.g., his appearance or his predisposition to certain genetic talents or conditions, he ineluctably would have an inferior existence. This argument, however, ignores the fact that other genetically identical individuals, e.g., identical twins, are not considered to be inferior beings, either socially or legally. Moreover, to characterize an individual conceived by cloning as lacking in free will because he shares his genes with another disregards the importance of innumerable environmental factors and assumes that genetics defines individual destiny to such an extent that nothing else matters. Despite society's current emphasis on and fascination with genetics, ${ }^{137}$ it seems clear that such genetic reductionism is not warranted by the evidence. ${ }^{138}$

\section{Abortion Law and the Problem of "Waste Embryos"}

Yet another commonly voiced fear regarding human cloning is the problem of so-called "waste embryos."139 Opponents of human cloning often cite the Dolly experiments as illustrative of the risks that would befall human embryos if human cloning were permitted, proclaiming that only one of the 277 attempts resulted in a live birth. ${ }^{140}$ The not-so-subtle, but misleading, insinuation of this statistic is that 276 out of 277 baby lambs died. ${ }^{141}$ As Lee Silver has noted, out of the 277 successful egg-nucleus fusions, only twenty-nine were able to be stimulated to begin the process of cell division. ${ }^{142}$ This means that only twentynine of Dr. Wilmut's 277 attempts (eleven percent of all attempts) created any sort of embryo at all. ${ }^{143}$ These twenty-nine lamb embryos were then implanted into the uteruses of thirteen different ewes, only one of which resulted in the live birth of a

137. See generally, Stephen Jay Gould, Dolly's Fashion and Louis's Passion, in Clones and Clones: Facts and Fantasies ABout Human Cloning 41-53 (Martha C. Nussbaum \& Cass R. Sunstein eds., 1998) (criticizing the current societal obsession with genetics).

138. See, e.g., NBAC REPORT, supra note 8, at 63.

139. See, e.g., id.

140. See, e.g., Annas, supra note 21, at 267:

Dollys birth was a 1-in-277-embryo chance. . . . The birth of a human from cloning might be technologically possible, but we could only discover this by unethically subjecting the planned child to the risk of serious genetic or physical injury, and subjecting a planned child to this type of risk will likely never be justified.

Id.; see also Anne Lawton, The Frankenstein Controversy: The Constitutionality of a Federal Ban on Cloning, 87 KY. L.J. 277, 352 (1998) ("If Dr. Wilmut's experiment is any indication, hundreds of thousands of embryos will be created and destroyed in the process of perfecting human cloning techniques. It took Dr. Wilmut 277 tries before he successfully created the clone known as 'Dolly."').

141. See Annas, supra note 21, at 267; Andrews, supra note 69, at 651-52.

142. SILVER, supra note 42, at 103.

143. See id.; accord NBAC REPORT, supra note 8, at 22 ("[O]nly 29 of $277(11 \%)$ of successful fusions between adult mammary gland nuclei and enucleated oocytes developed to the blastocyst stage...."). 
thirteen different ewes, only one of which resulted in the live birth of a lamb. ${ }^{144}$ Thus, the more accurate statistic associated with the Dolly experiments is that one of thirteen attempted pregnancies was successful. ${ }^{145}$ The remaining twelve pregnancies ended in natural miscarriage. ${ }^{146}$ The one lamb that was born (Dolly) is apparently quite normal and healthy. ${ }^{147}$

It is inevitable, given the current state of scientific know-how, that some embryos created by cloning would fail to develop and thrive. Precisely what percentage, however, is unclear. If the Dolly experiments are any indication, a rate of approximately one live birth for every thirteen pregnancies could be expected. The question, therefore, is whether a success rate-a "live birth rate"-of one in thirteen is morally or ethically acceptable. Perhaps one way to answer this question is to compare the "live birth rate" of one in thirteen pregnancies associated with the Dolly experiments to the "live birth rate" of existing reproductive techniques. An estimated sixty to seventy percent of all embryos created through sexual intercourse are never born. ${ }^{148}$ Fifteen percent of pregnancies end naturally through miscarriage. ${ }^{149}$ Many early stage embryos simply fail to thrive and are reabsorbed by the body, often because they are severely deformed. ${ }^{150}$ The percentage of live births from ARTs such as IVF is only about twenty percent. ${ }^{151}$ This means that of the embryos created by ART that are

144. See SILVER, supra note 42, at 103; accord NBAC REPORT, supra note 8, at 22. See also Stephenson, supra note 42, at 1025.

145. See SILVER, supra note 42, at 104.

146. Gina Kolata, Clone: The Road to Dolly and The Path ahead 239 (1998).

147. There has been unsubstantiated speculation that, because Dolly was created using adult cells, her cells may be "older" than that of a lamb created by other means. See id. at 239-41; NBAC REPORT, supra note 8, at 23. For a more detailed discussion of this and other possible health hazards associated with human cloning, see infra Part V.D.

148. See Ethical Considerations of Assisted Reproductive Technologies, 62 FERTILITY AND STERILITY 14S (1994) (Supp. 1) (report of the Ethics Committee of the American Fertility Society) [hereinafter American Fertility Soc'y Rep.]; accord R. Alta Charo, The Hunting of the Snark: The Moral Status of Embryos, Right-to-Lifers, and Third World Women, 6 STAN. L. \& Pol'y REv. 11, 16 (1995).

149. An even greater number of fertilized eggs are miscarried prior to a clinical diagnosis of pregnancy, perhaps $30 \%$ or more. See Gillian Bentley, Doing What Comes Naturally, NEW SCIENTIST, Aug. 31, 1996, at 43. The miscarriages of such small embryos often go unnoticed by the woman, as they do not even know they are pregnant. See id.

150. An estimated $40 \%$ of human embryos created by sexual reproduction do not successfully implant into the womb, and half of these-20\% of all human pregnancies-do not successfully implant because of a genetic defect. See PENCE, supra note 33, at 132 (citing A. Wilcox et al., Incidence of Early Loss of Pregnancy, 319 NEW ENG. J. MED. 18994 (1988)). The incidence of serious deformities in children conceived sexually is one to two percent. See id. at 133.

151. In 1995 (the latest year for which $C D C$ figures were available), the so-called "live per cycle rate," also colloquially referred to as the "take home baby rate," for ARTs was $19.6 \%$. See ASSISTED REPRODUCTIVE TECHNOLOGY SUCCESS RATES: NAT'L SUMMARY AND FERTILITY CliNIC REPS., Figure 6 (visited Mar. 30, 1998) <http://www.cdc.gov/nccdphp/drh/arts/fig6.htm> [hereinafter CDC Report]. This reported live birth rate has been criticized, however, as being overstated. See DEBORAH LYNN 
implanted into the woman's body, eighty percent are stillbirths, miscarriages, or more likely, never successfully implant into the womb at all. ${ }^{152}$

Countless other human embryos and pre-embryos ${ }^{153}$ are intentionally destroyed each year. Approximately one million embryos are aborted annually in the United States. ${ }^{154}$ Many other embryos created by ARTs such as IVF are discarded or donated for scientific experimentation. ${ }^{155}$ Countless more are stored, perhaps indefinitely, in a frozen state, neither discarded nor implanted. ${ }^{156}$ Indeed, the number of frozen embryos created by IVF became so high in Great Britain that in 1990, the British Parliament enacted a law mandating the destruction of frozen embryos after five years of storage. ${ }^{157}$ In 1996, the first year in which the five-year storage limit was in effect, an estimated 3300 frozen embryos were destroyed, an

("Despite claims by some IVF clinics of success rates upwards of $20 \%$, Gena Corea and Susan Ince found . . . that success rates for IVF treatment are routinely manipulated by clinicians in various ways. . . [ [N] rates of live birth [were found] higher than $10 \%$, and even those occurred only at the best clinics.").

152. The 1995 CDC Success Rates Report revealed that approximately only five percent of all clinical pregnancies achieved through ART resulted in adverse outcomes such as ectopic pregnancy, miscarriage, induced abortion, or stillbirth. See CDC Report, supra note 151, at Figures $8 \mathrm{a}, 8 \mathrm{~b}$. The remaining embryos created through ART (approximately $76 \%$ ) did not result in a "clinical" pregnancy, which means that although a human embryo was successfully created, no gestational sac was observable on ultrasound. See id. at Figures 6, 8a.

153. The term "pre-embryo" is used to denote an early-stage embryo up to approximately 14 days after fertilization, when the embryonic axis appears. See Ethical Considerations of Assisted Reproductive Technologies, 62 FERTILITY AND STERILITY 1245 (1994) (Supp. I) (report of the Ethics Committee of the American Fertility Society) [hereinafter AFS Report]. Lee Silver suggests that the term "pre-embryo" is, biologically speaking, meaningless; he posits that the term was developed for political reasons by IVF proponents seeking to avoid the ethical thicket associated with the term "embryo." See SILVER, supra note 42 , at 39 .

154. See Litmus-Test Folly, N.Y. TIMES, Jan. 12, 1998, at A20. It is estimated that 45 million abortions are performed worldwide each year. See Barbara Crossette, $A$ Global Divide on Abortion Splits Poor from Rich, N.Y. TIMES, June 7, 1998, $\$ 4$ at 16.

155. As John Robertson points out, most IVF clinics in the United States have a de facto policy against discarding embryos created by IVF due to opposition from right-tolife groups. They thus claim to transfer all successfully fertilized embryos into the uterus. John A. Robertson, Embryos, Families, and Procreative Liberty: The Legal Structure of the New Reproduction, 59 S. CAL. L. REv. 939, 977 (1986). Robertson also points out, however, that there are numerous situations in which the gamete donors or the health care institution may prefer to discard excess embryos, such as to avoid the risks of multiple births or when the gamete donors die before implantation can occur. See id.

156. Although there is no centralized data source, ART researchers estimate that the number of "abandoned" frozen embryos created through ART may be as high as 20,000. See Terence Monmaney, By Law, Britain to Destroy 3000 Frozen Embryos, L.A. TiMES, July 27, 1996, at Al.

157. See Human Fertilisation and Embryology Act, 1990, ch. 37 (Eng.), $§ 14$ (1)(c) and (4). 
act a Vatican newspaper deemed a "prenatal massacre."158 The problem of "waste embryos," therefore, is clearly not unique to cloning.

While these statistics give rise to legitimate ethical discussions about the propriety of abortion or discarding embryos created by ARTs, the legal implications under current law are clear. "Waste embryos," whether created by intercourse, cloning, or other ARTs, can occur in one of two ways: (1) naturally, through biological phenomena that renders the embryo unviable (i.e., miscarriage or reabsorption); and (2) intentionally, by aborting an already implanted embryo or by the destruction of an embryo that has not yet been implanted into a human womb. If a human embryo, however conceived, fails to develop and thrive because of natural, biological causes, there is, of course, no legal problem. ${ }^{159}$ If, on the other hand, a human embryo, however conceived, is intentionally destroyed, the law has an important role to play.

At the present time, the salient legal distinction to be drawn in the context of the intentional destruction of a human embryo appears to be whether the embryo has been implanted into a human womb. Furthermore, if the human embryo has been implanted into a human womb, the important distinction is whether or not the embryo is "viable" outside the womb. ${ }^{160}$ A pregnant woman may, prior to the point of viability, abort a fetus ${ }^{161}$ pursuant to a constitutional right initially pronounced in Roe v. Wade. ${ }^{162}$ After the point of viability, however, a state's interest in protecting the life of the unborn fetus is sufficiently strong that "the State . . may, if it chooses, regulate, and even proscribe, abortion except where necessary, in appropriate medical judgment, for the preservation of life or health of the mother."163

158. See James Walsh, A Bitter Embryo Imbroglio, Time, Aug. 12, 1996, at 10 (Int'l Edition).

159. The Model Penal Code, for example, recognizes four kinds of criminal intent or culpability: (1) purposely; (2) knowingly; (3) recklessly; and (4) negligently. See MODEL PENAL CODE $§ 210.2(1)$ (1962). If a human embryo created by cloning failed to thrive due to natural causes, neither the donor, the surrogate mother, nor the scientists involved could be said to have purposely, knowingly, recklessly, or negligently caused the embryo's death. Moreover, there would be no basis for the imposition of civil liability in this scenario because causation would be lacking.

160. See Planned Parenthood of Southeastern Pa. v. Casey, 505 U.S. 833, 846 (1992); see also id. at 870 (describing viability as the "time at which there is a realistic possibility of maintaining and nourishing a life outside the womb, so that the independent existence of the second life can in reason and in all fairness be the object of state protection that now overrides the rights of the woman").

161. See id. at 870 ("We conclude [that] the line should be drawn at viability, so that before that time the woman has a right to choose to terminate her pregnancy.").

162. 410 U.S. 113 (1973). The source of the constitutional right is a "liberty" interest under the Due Process Clause. See Casey, 505 U.S. at 846 ("Constitutional protection of the woman's decision to terminate her pregnancy derives from the Due Process Clause of the Fourteenth Amendment.").

163. Roe, 410 U.S. at 164-65. This aspect of Roe was reaffirmed by a majority of the Court in Casey, 505 U.S. at 879. 
Even prior to the point of viability, however, the state has an "important and legitimate interest in protecting the potentiality of human life." 164 Thus, if the pregnant woman's constitutional rights are not at issue (i.e., she does not want to terminate her pregnancy), the state may proscribe the killing of a fetus, even a previability fetus, by a third party. ${ }^{165}$ A minority of states, in fact, have done so, generally through the enactment of specific feticide statutes ${ }^{166}$ or by adding the term "fetus" to various criminal laws prohibiting murder or manslaughter. ${ }^{167}$

Applying these abortion law principles to cloning creates relatively clear results when the embryo is implanted into a human womb. Pursuant to Planned Parenthood of Southeastern Pa. v. Casey, a pre-viable embryo created by cloning that was implanted into a woman's womb could be disposed of intentionally (i.e., aborted) by the woman. ${ }^{168}$ If, however, the DNA donor and the woman in whose womb the child is implanted (i.e., the surrogate) are not the same person (as would always be the case when a male cloned himself), Casey implies that only the surrogate would have a constitutional right to abort; the DNA donor would be powerless to stop it. ${ }^{169}$ This result makes sense because it is the pregnant woman who endures the anxieties and physical restraints the Court referred to in Casey. ${ }^{170}$ It is also consistent with current notions of surrogate motherhood, as no one has seriously suggested that the "parents" of a child being carried by a surrogate mother could force the surrogate mother to carry to term. ${ }^{171}$

But what of a human embryo that has not been implanted into a human womb, such that technically there is no "pregnancy"? If an in vitro human embryo is created by cloning or other ARTs and then intentionally discarded, the constitutional right pronounced in Roe appears to be inapposite. A majority of the Court in Casey defined the constitutional right of abortion as belonging to the "woman" or "mother" inside whose body the fetus grows:

[T] he liberty of the woman is at stake in a sense unique to the human condition and so unique to the law. The mother who carries a child to full term is subject to anxieties, to physical constraints, to

164. Roe, 410 U.S. at 162; see also Casey, 505 U.S. at 871.

165. See, e.g., Clarke Forsythe, Homicide of the Unborn Child: The Born Alive Rule and Other Legal Anachronisms, 21 VAL. U. L. REV. 563, 616 (1987); Patricia A. King, The Juridical Status of the Fetus: A Proposal for Legal Protection of the Unborn, $77 \mathrm{MiCH}$. L. REv. 1647, 1678 (1979); Jeffrey A. Parness, Crimes Against the Unborn: Protecting and Respecting the Potentiality of Human Life, 22 HARV. J. ON LEGIS. 97, 144 (1985).

166. See, e.g., GA. CODE ANN. § 16-5-80 (2000); LA. REV. STAT. ANN. § 32.5 (West 1997).

167. See, e.g., CAL. PeNal CODE $\S 187$ (a) (West 1999) ("Murder is the unlawful killing of a human being, or a fetus, with malice aforethought."); People v. Davis, 872 P.2d 591, 599 (Cal. 1994) (interpreting California murder statute to include a pre-viable fetus); see also MicH. COMP. LAWS $\S 750.322$ (1997) (deeming the willful killing of an "unborn quick child" to be manslaughter).

168. See supra notes 160-162 and accompanying text.

169. See generally Casey, 505 U.S. 833 (1992).

170. See id. at 852 .

171. This is not to say, of course, that the surrogate mother who aborts would be immune from possible liability for breach of contract. 
pain that only she must bear. ... Her suffering is too intimate and personal for the State to insist, without more, upon its vision of the woman's role, however dominant that role has been in the course of our history and our culture. The destiny of the woman must be shaped to a large extent on her own conception of her spiritual imperatives and her place in society. ${ }^{172}$

Thus, if an embryo is not implanted into a woman's body, the woman's constitutional rights as pronounced in Roe $v$. Wade and its progeny cannot, by definition, be violated, because the woman's rights to bodily autonomy and privacy are not affected.

Current law suggests that if a human embryo has not been implanted into a human womb, it is not legally considered a "person," and therefore generally may be used, frozen, or disposed of by the gamete providers. ${ }^{173}$ Indeed, states currently do not criminalize discarding or donating for scientific experimentation pre-implantation embryos that are created by IVF or other ARTs. Instead, preimplantation human embryos are generally regarded as a unique type of property, over which the gamete donors have ultimate dispositional authority. ${ }^{174}$

The landmark case in this regard, Davis $v$. Davis, ${ }^{175}$ involved a dispute by a divorced couple over the disposition of nine frozen embryos created by IVF prior to their divorce. ${ }^{176}$ The Tennessee Supreme Court concluded that the frozen embryos were neither "persons" nor "property" under Tennessee law but instead "occup[ied] an interim category that entitles them to special respect because of their potential for human life."177 Nonetheless, the court held that the gamete providers, while not possessing a "true property interest," had "an interest in the nature of ownership, to the extent that they have decision-making authority concerning disposition of the pre-embryos."

The "frozen embryo" cases thus provide a workable analytical and legal framework for dealing with pre-implantation human embryos created by cloning.

172. Casey, 505 U.S. at 852 .

173. See Davis v. Davis, 842 S.W.2d 588, 597 (Tenn. 1992). See also York v. Jones, 717 F. Supp. 421, 426-27 (E.D. Va. 1989) (holding that Cytopreservation Agreement entered into between gamete donor/parents and IVF clinic "fully recognize[d] plaintiffs' property rights in the pre-zygote and limited [the defendant clinic's] rights as bailee to exercise dominion and control over the pre-zygote"). Some states, however, have enacted specific statutes which grant pre-embryos specific legal protection as "persons." See, e.g., LA. REv. STAT. ANN. \$§ 9:12I-133 (West 2000).

174. But see LA. REv. STAT. $\S 9: 130$ (2000) ("An in vitro fertilized human ovum is a juridical person which cannot be owned by the in vitro fertilization patients who owe it a high duty of care and prudent administration.") (emphasis added).

175. 842 S.W.2d 588 (Tenn. 1992).

176. See id. at 592 .

177. Id. at 597.

178. Id.; accord Hecht v. Superior Court, 20 Cal. Rptr. 2d 275, 281, 283 (Ct. App. 1993) (holding frozen sperm to also occupy the "interim category" between property and persons and allowing deceased donor to donate such sperm to girlfriend via testamentary disposition). 
If the case of Dolly the sheep is any indication, the human embryos created by cloning that potentially would be discarded would be very early stage embryos called blastocysts. ${ }^{179}$ Since these blastocysts would likely be discarded or destroyed prior to implantation, current law suggests that they should be treated as a unique form of property subject to the dispositional authority of the gamete donor. In the case of cloning, the donor is the individual who donates the child's genetic material (i.e., the DNA donor) ${ }^{180}$ Moreover, given that a human embryo created by cloning has a genetic link to only one person (rather than two), the likelihood of disputes arising over the disposition of such pre-implantation embryos is even less than in the context of existing ARTs.

Another as yet theoretical possibility is the intentional destruction of a human embryo, whether created by cloning, another ART, or intercourse, after it has been placed into an artificial womb. ${ }^{181}$ Under this scenario, the abortion cases, ${ }^{182}$ with their bases in the protection of bodily autonomy and privacy, seem inapposite, since no implantation into a woman's body has occurred. Thus, human embryos placed inside artificial wombs would fall outside the realm of current abortion rights law. Since there would be no woman's body involved (and hence, no "competing" interest with the rights of the embryo), presumably states would be free to assert their right to protect such unborn human embryos. The destruction of human embryos placed in artificial wombs could, therefore, be prohibited, even prior to the point of viability, if the state chose to do so.

While legislative prohibition against the destruction of human embryos placed in artificial wombs would be constitutionally permissible, such legislation would likely require the amendment of many existing criminal statutes. This is so because most states, either by explicit statutory language or judicial construction, have interpreted the term "person" or "human being" in their criminal laws as excluding unborn fetuses. ${ }^{183}$ Several states have, however, enacted specific feticide

179. See NBAC REPORT, supra note 8, at 21-22, app. 1 (defining "blastocyst" as "the developing preimplantation embryo, beginning about 4 days after fertilization").

180. I acknowledge that the egg donor could, in theory, assert a right of control over the disposition of the pre-implantation embryo based upon the presence of her mitochondrial DNA. Given, however, the relatively small and obscure genetic role of mitochondrial DNA, courts may not be willing to grant the egg donor such lofty status. Moreover, as a pragmatic matter, an egg donor (who is usually anonymous) is unlikely to desire to exercise such dispositional authority, even assuming arguendo that a court were willing to grant it.

181. Although artificial wombs have not yet been successfully created for any animals, a team of Japanese researchers has succeeded in sustaining goat fetuses outside the womb in an "extrauterine fetal incubation" device for up to three weeks. See Artificial Womb Can Sustain Goat Fetus for up to 3 Weeks, CHI. TrIBUNE, July 20, 1997, at C8; Perri Klass, Behind Closed Doors: The Artificial Womb Is Born, N.Y. TimES, Sept. 26, 1996, at 117.

182. See e.g., Planned Parenthood of Southeastern Pa. v. Casey, 505 U.S. 833 (1992); Roe v. Wade, 410 U.S. 113 (1973).

183. This is the common law "born alive" rule. See, e.g., Kansas v. Trudell, 755 P.2d 511 (Kan. 1988); Louisiana v. Brown, 378 So. 2d 916, 917-18 (La. 1979); North Carolina v. Beale, 376 S.E.2d 1, 2 (N.C. 1989). 
statutes or interpreted the common law to impose criminal liability if a fetus is viable or quick. ${ }^{184}$ Nonetheless, the intentional destruction of a human fetus that is not yet viable outside the womb is generally not considered to constitute a crime. ${ }^{185}$

Any legislative prohibition on the destruction of human embryos placed in artificial wombs would likely spawn extensive debate about the propriety of permitting the continuation of intentional destruction of human embryos not placed in artificial wombs (e.g., embryos created by IVF and not implanted into a human womb). ${ }^{186}$ States could theoretically require that all human embryos not implanted into human wombs be placed inside artificial wombs and, if possible, grown to term. Such laws, however, would be very expensive to enforce and would require extensive consideration regarding, inter alia, parental and inheritance rights. ${ }^{187}$

\section{Possible CONSTITUTIONAL IMPEDIMENTS TO BANNING HuMAN CLONING}

While there is undoubtedly great popular support for banning human cloning both at the federal and state level, there are several possible constitutional impediments to doing so. Even if cloning bans are enacted (as they have already been in several states), such bans likely will be challenged on various constitutional grounds. This section explores the likelihood of success of such challenges.

\section{A. The First Amendment: A Right of "Scientific Inquiry"?}

The opponents of human cloning do not seem content with a ban on governmental funding of human cloning research, which has already been implemented. ${ }^{188}$ Rather, they seek to ban all human cloning research, regardless of whether the research is conducted with public or private dollars. ${ }^{189}$ In effect, the

184. See, e.g., FLA. STAT. ANN. Ch. 782.09 (2000); GA. CODE ANN. $\$ 16-5-80$ (1998); WIS. STAT. § 940.04(2)(a) (1999); Commonwealth v. Cass, 467 N.E.2d 1324, 1329 (Mass. 1984). Only a few states have enacted statutes criminalizing the death of a previable fetus. See, e.g., ARIZ. REv. StAT. ANN. § 13-1103(A)(5) (West 1999); IND. CoDE ANN. § 35-42-1-6 (Michie 1998).

185. See, e.g., Larkin v. Wayne Prosecutor, 208 N.W.2d 176, 180 (Mich. 1973).

186. As discussed extensively, many human embryos created by IVF are never implanted into human wombs and are discarded, destroyed, or frozen indefinitely. See supra notes 151-158 and accompanying text.

187. While recognizing the importance of these issues, consideration of them is beyond the scope of this Article.

188. Memorandum on the Prohibition on Federal Funding for Cloning of Human Beings, 33 WeEKLY COMP. PRES. DOC. 281 (Mar. 4, 1997).

189. See, e.g., S. 1599, 105th Cong., 2d Sess. (1998) (Sen. Bond); S. 1601, 105th Cong., 2d Sess. (1998) (Sen. Lott); S. 1602, 105th Cong., 2d Sess. (1998) (Sen. Feinstein); S. 1611, 105th Cong., 2d Sess. (1998) (Sen. Feinstein); H.R. 923, 105th Cong., 1st Sess. (1997) (Rep. Ehlers). 
current cloning ban proposals would say to scientists, "thou shalt not research" in this particular area. ${ }^{190}$

As an initial matter, it should be noted that a simple ban on federal funding of scientific research is not constitutionally troubling. Congress has the power, pursuant to the Spending Clause, to spend federal dollars in any way it wishes, so long as the spending can be said to be within the broad notion of the "general welfare." deny federal funding of scientific research it deems not in furtherance of the general welfare. ${ }^{192}$ The Executive Branch may likewise restrict federal funding, provided it is not contrary to statutory language. In the mid-1970s, for example, the National Institutes of Health ("NIH") and other federal agencies promulgated regulations restricting federal funding of recombinant DNA research that did not conform to certain guidelines. ${ }^{193}$ Likewise, in the 1980s, the Reagan and Bush Administrations imposed a fetal tissue research ban, which specified that federal dollars could not be spent on fetal tissue research. ${ }^{194}$ The rationale behind the

190. Past experience with such prohibitions on scientific research are illuminating. Galileo Galilei, an Italian astronomer of the early 17th century, posited the theory that the Earth revolved around the sun, in contradiction to the well accepted contemporary belief that the Earth was the center of the universe. See generally WILL \& ARiel Durant, The Age of Reason Begins, The Story of Civilization, Part Vil 60611 (1961). After defying an order from the Catholic Church to cease dissemination of his theory, Galileo became the subject of an Inquisition, which found him guilty of heresy. See id.

191. U.S. CONST. art. I, $\S 8, \mathrm{cl} .1$ (stating that "[t] $]$ he Congress shall have Power . . . to pay the Debts and provide for the common Defence and general Welfare of the United States...").

192. In Rust v. Sullivan, the Court stated:

The Government can, without violating the Constitution, selectively fund a program to encourage certain activities it believes to be in the public interest, without at the same time funding an alternative program which seeks to deal with the problem in another way. In so doing, the Government has not discriminated on the basis of viewpoint; it has merely chosen to fund one activity to the exclusion of another.

Rust v. Sullivan, 500 U.S. 173, 193 (1991); see also Harris v. McRae, 448 U.S. 297, 317 (1980) ("A refusal to fund protected activity, without more, cannot be equated with the imposition of a 'penalty' on that activity.").

193. See Harold P. Green, Constitutional Implications of Federal Restrictions on Scientific Research and Communication, 60 UMKC L. REV. 619, 622-23 (1992). Professor Green suggests that the NIH Guidelines were based upon voluntary guidelines developed by an international conference of recombinant DNA scientists held at Asilomar, California, in February 1975. See id. at 622.

194. See Gina Kolata, Federal Agency Bars Implanting of Fetal Tissues, N.Y. TimES, Apr. 16, 1988, at Al. The fetal tissue ban was implemented by an Assistant Secretary for Health of the Department of Health \& Human Services, see id., and was never published in the Federal Register. The ban was lifted by Executive Order of President Clinton on Jan. 22, 1993. See 58 FED. REG. 7457 (1993); 29 WeEKLY COMP. Pres. 87 (Jan. 22, 1993). A few months after President Clinton lifted the moratorium, Congress enacted a law which allows federal funding of fetal tissue research provided certain requirements are 
restriction was that federal funding of such research would create a need for fetal tissue, which in turn could encourage more women to have abortions. ${ }^{195}$

The research restrictions on recombinant DNA and fetal tissue were qualitatively different from the proposed federal or state bans on human cloning because they merely restricted public funding of such research and did nothing to prevent such research from being funded by private dollars. The proposed bans on human cloning, by contrast, would prohibit all cloning research or specific applications thereof, whether publicly or privately funded. ${ }^{196}$

The question therefore becomes whether a law banning all cloning research, or specific applications thereof, would run afoul of the First Amendment, which states that "Congress shall make no law . . . abridging the freedom of speech . . .."197 It is well accepted, of course, that the First Amendment is not absolute. ${ }^{198}$ Even protected speech may be regulated, provided the law in question is necessary to further a compelling governmental interest. ${ }^{199}$ It is necessary, therefore, to determine whether scientific research-such as human cloningconstitutes "speech," and, if so, to what extent such speech is protected.

One of the most commonly held views of the Founders' purpose in drafting the First Amendment is that it was designed to ensure robust discussion through protection of the "marketplace of ideas."200 Another common view is that the First Amendment is designed to protect speech and expressive conduct which is essential to informed self-governance. ${ }^{201}$ Alexander Meiklejohn posits that the First Amendment was designed to ensure the existence of a well-informed citizenry capable of self-governance by protecting such things as education,

met, such as informed consent of the donor, donee, and researcher, and the availability of record keeping subject to audit by federal officials. See 42 U.S.C. $\$ 289 \mathrm{~g}-1-2$ (1994).

195. See Kolata, supra note 194.

196. See supra note 189.

197. U.S. CONST. amend. I. The First Amendment has been incorporated to apply to the states via the Due Process Clause of the Fourteenth Amendment. See Gitlow v. New York, 268 U.S. 652 (1925). Therefore, any state laws attempting to ban human cloning would likewise potentially violute the First Amendment.

198. JOHN E. NOWAK \& RONALD D. ROTUNDA, CONSTITUTIONAL LAW § 16.7(b) at 994 (5th ed. 1995).

199. See Buckley v. Valeo, 424 U.S. 1, 26-27 (1976) (upholding federal law limiting contribution limits to federal political candidates).

200. Red Lion Broad. Co. v. FCC, 395 U.S. 367, 390 (1969); see also Abrams v. United States, 250 U.S. 616, 630 (1919) (Holmes, J., dissenting); Thomas I. Emerson, Colonial Intentions and Current Realities of the First Amendment, 125 U. PENN. L. REV. 737,741 (1977) ("The essential point is that the process [of advancing knowledge of the citizenry] is necessary for reaching the best social decision, regardless of whether ultimate values are.").

201. See generally Emerson, supra note 200, at 741-42; Alexander Meiklejohn, The First Amendment Is an Absolute, 1961 SUP. CT. REv. 245 (1961). 
philosophy, science, literature, and the arts, and public discussions of public issues. ${ }^{202}$ He concludes:

I believe, as a teacher, that the people do need novels and dramas
and paintings and poems, "because they will be called upon to
vote." The primary social fact which blocks and hinders the success
of our experiment in self-government is that our citizens are not
educated for self-government. We are terrified by ideas, rather than
challenged and stimulated by them. Our dominant mood is not the
courage of people who dare to think. It is the timidity of those who
fear and hate whenever conventions are questioned.

Thus, the First Amendment protects ideas, not because of their substantive merit but simply because ideas stimulate thought, which in turn breeds the courage and boldness necessary for effective self-governance. ${ }^{204}$ And while cloning research is clearly disturbing to many, the Supreme Court has stated that "the First Amendment ordinarily prohibits courts from inquiring into the content of expression, except in cases of obscenity or libel, and protects speech . . . regardless of [its] motivation, orthodoxy, truthfulness, timeliness, or taste."205 Indeed, the Court's obscenity jurisprudence is illuminating. Obscenity is beyond protection of the First Amendment ${ }^{206}$ because it "lacks serious literary, artistic, or scientific value" ${ }^{\text {207 }}$ that might reasonably contribute to the marketplace of ideas or effective self-governance. By necessary implication, therefore, expressive activity which does have serious "scientific value," regardless of its orthodoxy or taste, should, as a normative matter, be protected. ${ }^{208}$ If the paradigmatic example of what

202. But see Robert H. Bork, Neutral Principles and Some First Amendment Problems, 47 IND. L.J. 1 (1971) (arguing that the First Amendment protects only political speech and does not extend to other forms of expression such as science or the arts).

203. Meiklejohn, supra note 201, at 263.

204. See Emerson, supra note 200, at 741; Melville B. Nimmer, Does Copyright Abridge the First Amendment Guarantees of Free Speech \& Press?, 17 UCLA L. REv. 1180,1189 (1970) (arguing that the First Amendment protects ideas without regard to the form of expression).

205. Branzburg v. Hayes, 408 U.S. 665,705 n.40 (1972).

206. See, e.g., Paris Adult Theatre I v. Slaton, 413 U.S. 49 (1973); Roth v. United States, 354 U.S. 476 (1957).

207. Miller v. California, 413 U.S. 15, 24 (1973) (emphasis added).

208. Id. at 34 (concluding that the "First Amendment protects works which, taken as a whole, have ... scientific value, regardless of whether the government or a majority of the people approve of the ideas these works represent").

A letter dated October 26, 1774, from the Continental Congress to the inhabitants of the Province of Quebec, indicates that the Framers may well have assumed that the First Amendment protected scientific inquiry:

The last right we shall mention, regards the freedom of the press. The importance of this consists, besides the advancement of truth, science, morality and arts in general, in its diffusion of liberal sentiments on the administration of Government, its ready communication of thoughts between subjects, and its consequential promotion of union among them, whereby oppressive officers are shamed or intimidated, into more honourable and just modes of conducting affairs. 
is protected against governmental encroachment by the First Amendment is "ideas" with serious literary, artistic, or scientific value, then the penultimate scientific idea, ${ }^{209}$ the hypothesis, should likewise fall within the ambit of protected expression. ${ }^{210}$

But what of scientific action? Can a scientist be punished for action, i.e., for testing certain kinds of hypotheses? After all, once a scientific idea or hypothesis is formed, the scientist naturally wants to test his hypothesis through the scientific method. Any hypothesis untested by research or experimentation is relatively useless. ${ }^{211}$ The legislative bans on human cloning enacted thus far do not prohibit anyone from thinking about human cloning, but from acting upon their thoughts by engaging in certain actions. ${ }^{212}$ The proposed federal anti-cloning bills, for example, would prohibit either: (1) all use of somatic cell nuclear transfer techniques; ${ }^{213}$ or (2) the implantation into a mother's womb of a human embryo

Near v. Minnesota, 283 U.S. 697,717 (1931). Although the quoted passage refers to the freedom of the "press," it seems logical that the Framers were referring to the First Amendment generally, including freedom of speech. It would make little sense, after all, to allow the press to publish matters relating to the advancement of science if scientists were prohibited from engaging in activities that advanced science.

209. See Palko v. Connecticut, 302 U.S. 319, 326-27 (1937) ("[F]reedom of thought and speech . . . is the matrix, the indispensable condition, of nearly every other form of freedom."); see also Jones v. Opelika, 316 U.S. 584, 618 (1942) (Murphy, J., dissenting) ("Freedom to think is absolute of its own nature; the most tyrannical government is powerless to control the inward workings of the mind.").

210. See Emerson, supra note 200, at 741 ("The theory of freedom of expression ... developed in conjunction with, and as an integral part of, the growth of the scientific method."); id. at 742 ("[T]he scope of the constitutional protection [of the First Amendment] was intended to extend to religion, art, science, and all areas of human learning and knowledge."). But see Bork, supra note 202, at 27-28 ("The category of protected speech should consist of speech concerned with governmental behavior, policy or personnel .... It does not cover scientific, educational, commercial or literary expressions as such.").

211. See Sweezy v. New Hampshire, 354 U.S. 234, 262-63 (1957) (Frankfurter, J., concurring) ("Freedom to reason and freedom for disputation on the basis of observation and experiment are the necessary conditions for the advancement of scientific knowledge.") (citation omitted).

212. See, e.g., CAL. HEALTH \& SAFETY CODE $§ 24185$ (a) (2000) ("No person shall clone a human being"); CAL. HEALTH \& SAFETY CODE $\S 24185$ (c) ("For purposes of this section, 'clone' means the practice of creating or attempting to create a human being by transferring the nucleus of a human cell from whatever source into a human egg from which the nucleus has been removed for the purpose of, or to implant, the resulting product to initiate a pregnancy that could result in the birth of a human being."); MicH. COMP. LAWS § 333.16274-75 (1999) (prohibiting "engag[ing] in or attempt[ing] to engage in human cloning"); MicH. COMP. LAWS $\S 333.16274$ (4)(a) (defining human cloning as "the use of human somatic cell nuclear transfer technology to produce a human embryo").

213. See, e.g., S. 1599, 105th Cong., 2d Sess. § 3(a) (1998) (Sen. Bond) (making it "unlawful for any person or entity, public or private, in or affecting interstate commerce, to use human somatic cell nuclear transfer technology"); S. 1601, 105th Cong., 2d Sess. § 3(a) (1998) (Sen. Lott) (same); cf. H.R. 923, 105th Cong., 1st Sess. § 2 (1997) (Rep. Ehlers) 
created by cloning. ${ }^{214}$ The former would prohibit all scientific experimentation using cloning techniques (whatever the ultimate goal of the scientist may be), whereas the latter would prohibit a scientist from actually implanting a human embryo created by cloning. Both, of course, ban action, not thoughts.

May such scientific action be proscribed consistent with the First Amendment? The Supreme Court has long held that the First Amendment Free Speech Clause protects "expressive conduct," such as the wearing of black armbands in protest of the Vietnam War, ${ }^{215}$ the display of an American flag with a superimposed peace symbol, ${ }^{216}$ or the refusal of school children to salute the flag. ${ }^{217}$ While almost all speech arguably contains an element of conduct, the Court, in Spence v. Washington, ${ }^{218}$ articulated a two-part test for determining whether conduct is sufficiently expressive as to warrant First Amendment protection: (1) the conduct must be intended to "convey a particularized message"; and (2) there must be a "great" likelihood that "the message would be understood by those who view[] it." ${ }^{219}$ Even if conduct is considered sufficiently expressive so as to fall within the protective ambit of the First Amendment, the Court has made it clear that such expressive conduct may nonetheless be regulated if the regulation "furthers an important or substantial governmental interest; if the governmental interest is unrelated to the suppression of free expression; and if the incidental restriction on First Amendment freedoms is no greater than is essential to the furtherance of that interest." 220 In other words, the government may regulate expressive conduct provided such regulation serves an important, non-contentbased interest, and the regulation is narrowly tailored.

Would scientific research satisfy the two-pronged test of Spence $v$. Washington? Scientific research and experimentation is undoubtedly intended to "convey a particularized message" about the value and utility of underlying intellectual ideas-an unmistakable message to all who view the resulting

("It shall be unlawful for any person to use a human somatic cell for the process of producing a human clone.").

214. See, e.g., S. 1602, 105th Cong., 2d Sess. (1998) (making it unlawful to "implant or attempt to implant the product of somatic cell nuclear transfer into a woman's uterus"); S. 1611, 105th Cong., 2d Sess. (1998) (same); S. 1574, 105th Cong., 2d Sess. (1998) (declaring unlawful the "practice of creating or attempting to create a human being by transferring the nucleus from a human cell from whatever source into a human egg cell from which the nucleus has been removed for the purpose of, or to implant, the resulting product to initiate a pregnancy that could result in the birth of a human being").

215. See Tinker v. Des Moines Sch. Dist., 393 U.S. 503 (1969) (wearing of black armband in protest of Vietnam War constitutes expressive conduct protected by the First Amendment).

216. See Spence v. Washington, 418 U.S. 405 (1974) (displaying American flag with peace symbol superimposed was protected by First Amendment because it was essentially a form of expression).

217. See West Virginia State Bd. of Educ. v. Barnette, 319 U.S. 624 (1943) (finding that compulsory flag salutation violates First Amendment).

218. 418 U.S. 405 (1974).

219. Id. at $410-11$.

220. United States v. O'Brien, 391 U.S. 367, 377 (1968). 
scientific data. A scientist conducts experiments to either prove or disprove a hypothesis through the scientific method. ${ }^{221}$ Through experimentation, scientists express their creativity and intellectuality in much the same way that musicians express themselves through music or artists express themselves through art. A law which banned scientific research on human cloning could therefore interfere with the conveyance of a message in the same way as would a law which banned impressionistic painting or rap music. ${ }^{222}$

A more narrow legislative ban on certain specific applications of human cloning research, such as a ban only on the implantation of the embryo into a womb, could also present First Amendment problems. Under such legislation, the banned conduct-implantation of a human embryo created by cloning into a womb-arguably is "intend[ed] to convey a particularized message" that would have a "great" likelihood of being "understood by those who viewed it."223 The message being sent by an attempt at implantation would be that "human cloning is normatively worthwhile and technologically possible"-a message with a great likelihood to be understood by most people who viewed or otherwise learned of the attempted implantation.

By attempting implantation, a scientist would be applying the knowledge she has gained from scientific research. Attempting implantation is therefore a natural and logical next step, a step fully as expressive as, for example, performing a play one has written or singing a song one has composed. Absent a compelling interest, ${ }^{224}$ the government could no more ban the performing of a play than the writing of it. If human cloning research is expressive conduct protected by the First Amendment, so too should be the actual expression of that research (e.g., implantation).

Of course, a ban on a specific application of cloning research (e.g., implantation) does have one constitutional advantage over a broader ban on all cloning research: its specificity. Assuming arguendo that both pure and applied cloning research are considered expressive conduct deserving of First Amendment protection, a law prohibiting certain applications of human cloning research would, by its very nature, be more narrowly drawn than a law banning all human cloning research. A ban on cloning implantation would, therefore, be more likely

221. See Daubert v. Merrell Dow Pharmaceuticals, Inc., 509 U.S. 579, 590 (1993).

222. See Melville B. Nimmer, The Meaning of Symbolic Speech Under the First Amendment, 21 UCLA L. REv. 29, 35 (1973) ("It would be shocking to conclude that symphonic compositions or nonrepresentational art could be the subject of governmental censorship. Both are fully within the ambit of the first amendment notwithstanding their lack of both verbal and cognitive content.").

223. Spence, 418 U.S. at $410-11$.

224. Whether a ban on human cloning would, in fact, be necessary to further a compelling governmental interest is discussed infra Part V. 
to be upheld, since it would be more "narrowly tailored" to further the identified important governmental interest. ${ }^{225}$

Of course, not all expressive conduct that is intended to convey a message is protected by the First Amendment. The government may still regulate expressive conduct so long as the regulation is unrelated to the content of the idea being expressed. ${ }^{226}$ Melville Nimmer provides an excellent example of the importance of the content-based versus non-content-based distinction: the assassination of Robert Kennedy by Sirhan Sirhan. ${ }^{227}$ While Sirhan undoubtedly intended to convey a message by his violent act, his conduct was not protected by the First Amendment because the state's prohibition of his conduct (i.e., assassination) was unrelated to the content of the message Sirhan intended to convey. ${ }^{228}$ Governmental prohibition against assassination has, in other words, a non-content based purpose of preventing murder and is therefore not a restriction on freedom of expression. ${ }^{229}$

Would a governmental bar on human cloning be content based? Opponents of human cloning would argue that such a ban would not be contentbased, but rather would have a non-content-based purpose of preventing harm to various interests such as family and the born and unborn child. ${ }^{230}$ But even assuming the opponents of cloning have such interests in mind, such interests are implicated only because of the content of the activity sought to be banned (i.e., cloning). In other words, it is the very nature of cloning which frightens its opponents. The fears about cloning's impact on family and the born and unborn children of cloning are intrinsically intertwined with fears about cloning qua cloning.

By way of analogy, suppose the government banned a certain rap CD because many who heard the songs on the $C D$ feared that the lyrics posed a threat to the traditional family structure or could cause psychological damage to children. Proponents of the ban would certainly argue that the purpose of enacting the ban was to protect the family or children, i.e., a non-content-based purpose. But does anyone seriously doubt, even assuming protection of family and children was the primary motivation of such a law, that the law is content based? The CD was banned because of the offensive content of the message contained within the song, a content which gave rise to fears about the CD's effect on family and children. The message contained in the $C D$ and the feared consequences of the message motivated the law banning the $C D$.

225. See Board of Airport Comm'rs. of Los Angeles v. Jews for Jesus, 482 U.S. 569, 573 (1987); Perry Educ. Ass'n v. Perry Local Educators' Ass'n, 460 U.S. 37, 45 (1983).

226. See United States v. O'Brien, 391 U.S. 367, 377 (1968).

227. See Nimmer, supra note 222, at 38-39.

228. See id. at 39.

229. See id.

230. See, e.g., Andrews, supra note 69, at 652-56; Leon R. Kass, The Wisdom of Repgnance: Why We Should Ban the Cloning of Humans, 32 VAL. U. L. REV. 679, 693-98 (1998). 
Likewise, any ban on human cloning would undoubtedly emanate from fears concerning the expressive content of cloning activity. A scientist who engages in cloning activity expresses the idea that "cloning is normatively desirable"-a type of expressive conduct that upsets many (if not most) people. ${ }^{231}$ It is this message and the feared consequences of this message that motivate a ban on human cloning.

Assuming that scientific research and/or experimentation is expressive conduct, there is still another question that must be answered: what kind of speech is it and what is the appropriate degree of judicial scrutiny to be applied to its restriction by the government? There are essentially two kinds of speech protected by the First Amendment: (1) commercial and (2) non-commercial. If speech is classified as commercial speech, it enjoys less protection, ${ }^{232}$ and regulations infringing such speech are subject to intermediate scrutiny by the courts. ${ }^{233}$ If speech is classified as non-commercial, by contrast, it enjoys the highest degree of protection, and any content-based regulations infringing such speech are subject to strict scrutiny. ${ }^{234}$

The precise contours of commercial speech remain an enigma. The paradigmatic example of commercial speech is, of course, advertising, ${ }^{235}$ but commercial speech can, at least in theory, encompass more than advertising. In Virginia State Board of Pharmacy v. Virginia Citizens Consumer Council,, ${ }^{236}$ the Court described commercial speech as "speech which does no more than propose a commercial transaction" such that it "is so removed from any exposition of ideas and from truth, science, morality, and arts in general . . . that it lacks all protection."237 Implicit in the Virginia Board of Pharmacy definition of commercial speech is an exemption for science and other expression which expounds ideas and furthers the purposes of the First Amendment. Later, in Central Hudson Gas \& Electric Corp. v. Public Service Commission of New York, ${ }^{238}$ the Court defined commercial speech as communication "related solely to the economic interests of the speaker and its audience."239 But the fact that the

231. See infra note 486 and accompanying text (noting that polls indicate only six to seven percent of Americans would want to clone themselves).

232. See Central Hudson Gas \& Elec. Corp. v. Public Serv. Comm'n. of N.Y., 447 U.S. 557, 563 (1980).

233. See id. at 564 .

234. See Turner Broad. Sys. v. FCC, 114 S.Ct. 2445,2459 (1994). Non-contentbased restrictions are subject to intermediate scrutiny. Id. There are also, of course, certain categories of non-commercial speech that are without any First Amendment protection, such as obscenity, fighting words, and incitement to illegal activity. See Erwin Chemerinsky, Constitutional Law: Principles \& Policies 800-01 (1997).

235. See, e.g., Greater New Orleans Broadcasting Ass'n. v. United States, 527 U.S. 173 (1999) (addressing advertising of casinos).

236. 425 U.S. 748 (1976).

237. Virginia State Bd. of Pharmacy v. Virginia Citizens' Consumer Council, 425

U.S. 748, 762 (1976); see also Central Hudson, 447 U.S. at 566.

238. $\quad 447$ U.S. $557(1980)$.

239. Central Hudson, 447 U.S. at 561. 
speaker has an economic motivation for his speech is insufficient, without more, to categorize his speech as commercial. ${ }^{240}$

In Central Hudson, the Court set forth a four-part test for determining the validity of restrictions on commercial speech: (1) the content of the speech must concern lawful activities and not be misleading; (2) the asserted governmental interest in regulating the speech must be substantial; (3) the regulation must directly advance the asserted governmental interest; and (4) the regulation must be no more extensive than necessary to serve the asserted governmental interest. ${ }^{241}$

The inability of the Central Hudson test to deal adequately with a regulation restricting human cloning research or experimentation is obvious. If a law banning human cloning is enacted, the speech at issue, scientific experimentation and/or research, would not be considered "lawful activity;" thus, the first part of the Central Hudson test would not be satisfied, and the activity would be without First Amendment protection.

Protection of commercial speech is limited to speech related to lawful commercial activities. ${ }^{242}$ The advertising or promotion of unlawful activities such as gambling, prostitution, or the use of drugs are unprotected by the First Amendment pursuant to the first prong of Central Hudson. ${ }^{243}$ This restriction makes sense, of course, since the First Amendment is not absolute and certainly was not intended to protect expression relating to unlawful activity. ${ }^{244}$

The difficulty in classifying scientific experimentation and/or research as commercial speech, therefore, is that such speech would lose all constitutional protection under the first prong of Central Hudson if Congress chose to outlaw certain types of experimentation and/or research, such as human cloning. Commercial speech, therefore, is protected only as long as Congress or state legislatures allow the activity to be lawfully conducted.

If scientific experimentation and research do more than merely propose a commercial transaction, however, they likely would be considered noncommercial speech and protected against governmental interference absent a compelling governmental interest. ${ }^{245}$ The question thus becomes: would cloning research and/or experimentation do more than merely propose a commercial transaction? The most likely answer is yes. Although scientists who engage in cloning research and/or experimentation may benefit economically from such activity, this alone is insufficient to transform their action into commercial

240. See Bolger v. Youngs Drug Prods. Corp., 463 U.S. 60, 66 (1983).

241. See id. at 566; accord Greater New Orleans Broadcasting Ass'n. v. United States, 527 U.S. 173 (1999).

242. See Central Hudson, 447 U.S. at 563-64.

243. See id.

244. See Pittsburgh Press Co. v. Pittsburgh Comm'n. on Human Relations, 413 U.S. 376, 388-89 (1973).

245. See Turner Broad. Sys. v. FCC, 114 S. Ct. 2445, 2459 (1994). 
speech. ${ }^{246}$ Advertising their services may or may not be commercial speech; that determination is beyond the scope of this Article. But certainly the experimentation and/or research, standing alone, is not "commercial" speech since it does much more than propose a commercial transaction ${ }^{247}$ and is not related "solely" to the economic interests of the scientist and her audience. ${ }^{248}$

Think about it this way: a lawyer who argues to a jury or judge on behalf of his client is not engaging in "commercial speech." While the lawyer may benefit economically from his advocacy, his speech is not "solely" related to his economic interests and does much more than propose a commercial transaction. Indeed, this is the nature of legal advocacy: it expresses ideas, interpretations of facts and law, on behalf of another individual or entity. If the lawyer advertises his services, this would undoubtedly constitute commercial speech. ${ }^{249}$ But the lawyer who engages in the practice of law is not engaged in commercial speech any more than the scientist who engages in scientific research and/or experimentation. The fact that individual expression occurs within the context of a commercial occupation does not transform the expression, without more, into commercial speech.

If, therefore, scientific research and/or experimentation is expressive conduct entitled to First Amendment protection, it would most likely constitute non-commercial speech and could not be restricted unless such restriction were necessary to further a compelling governmental interest, a topic that will be explored in Part V.

\section{B. Procreational Autonomy Under the "Liberty" Interest of the Due Process Clause}

The Due Process Clauses of the Fifth and Fourteenth Amendments prohibit, respectively, federal or state governments from depriving any individual of "life, liberty, or property without due process of law."250 These clauses have long been interpreted as not only providing protection against procedural unfairness but also as providing positive, substantive protection against governmental deprivations of life, liberty, or property. ${ }^{251}$

246. See Bolger, 463 U.S. at 67 ("[T] motivation for mailing the pamphlets would clearly be insufficient by itself to turn the materials into commercial speech.").

247. See Virginia State Bd. of Pharmacy v. Virginia Citizens Consumer Council, 425 U.S. 748, 762 (1976); see also Central Hudson, 447 U.S. at 566.

248. Central Hudson, 447 U.S. at 561.

249. See, e.g., Bates v. State Bar of Arizona, 433 U.S. 350 (1977).

250. U.S. CONST. amends. V and XIV, $\S 1$.

251. See Planned Parenthood of Southeastern Pa. v. Casey, 505 U.S. 833, 846 (1992) (stating that the Due Process Clause of the Fourteenth Amendment "has been understood to contain a substantive component as well, one "barring certain government actions regardless of the faimess of the procedures used to implement them"') (citations omitted). An interesting question also exists as to whether the newly revitalized Privileges \& Immunities Clause of the Fourteenth Amendment may also provide substantive 
In the recent decision of Washington $v$. Glucksberg, ${ }^{252}$ the Court was hesitant to extend substantive due process rights, stating that:

[B]y extending constitutional protection to an asserted right or liberty interest we, to a great extent, place the matter outside the arena of public debate and legislative action. We must therefore "exercise the utmost care whenever we are asked to break new ground in this field," lest the liberty protected by the Due Process Clause be subtly transformed into the policy preferences of the members of the Court. 253

The Glucksberg Court also proclaimed that there are two salient features of substantive due process analysis: (1) consideration of the nation's history and traditions, restricting protection to liberties that are objectively "deeply rooted" in such history and tradition; and (2) a "careful description" of the liberty interest being asserted. 254

The Glucksberg Court's development of the second substantive due process prerequisite-a "careful description" of the liberty interest being asserted-may provide the necessary delineation for a constitutional right of procreation. ${ }^{25}$ Individuals clearly have a constitutional right not to procreate, which includes the rights to use contraceptives ${ }^{256}$ and to abort prior to fetal viability. ${ }^{257}$ A positive right to procreate is less clear and must, if it exists, be implied from a series of Court decisions addressing the relatively rare situation in which a state has attempted to prevent conception. While most legal commentators believe that a positive right of procreation exists, they differ with regard to defining its content and meaning. ${ }^{258}$

One of the most important cases implying a positive right of procreation is the 1923 decision in Meyer v. Nebraska, ${ }^{259}$ in which the Supreme Court struck down a Nebraska law which prohibited the teaching of any language other than English to children prior to the eighth grade. ${ }^{260}$ Specifically, the Court held that the law violated the "liberty" interest protected by the Due Process Clause of the Fourteenth Amendment, ${ }^{261}$ stating in dicta:

protection for certain rights thus far deemed fundamental by the Court under its substantive due process analysis. See generally Saenz v. Roe, 526 U.S. 489 (1999) (invalidating under Privileges and Immunities Clause a California law denying full welfare benefits to California newcomers for their first year of residency).

252. 521 U.S. 702 (1997).

253. Id. at 720 (citations omitted).

254. Id.

255. Id.

256. See Griswold v. Connecticut, 381 U.S. 479 (1973).

257. See Roe v. Wade, 410 U.S. 113 (1973).

258. See generally Wu, supra note 21; Robertson, supra note 155; see also Chester, supra note 21, at 313, n.33; Lawton, supra note 140, at 332-55.

259. 262 U.S. 390 (1923).

260. Id. at $400-03$.

261. The Due Process Clause of the Fourteenth Amendment states: "[N]or shall any State deprive any person of life, liberty, or property, without due process of law." U.S. 
Without doubt, [the liberty interest of the Due Process Clause] denotes not merely freedom from bodily restraint but also the right of the individual ... to marry, establish a home and bring up children ... and generally to enjoy those privileges long recognized at common law as essential to the orderly pursuit of happiness by free men. ${ }^{262}$

Thus, the liberty interest protected by the Constitution appeared to the court, in 1923, to encompass much more than simply a right to be free from physical restraint; it encompassed affirmative rights to the essentials of individual domestic happiness: marriage, establishment of a home, and the raising of children. ${ }^{263}$

The Supreme Court subsequently and more specifically addressed the right of procreation in the case of Skinner $v$. Oklahoma, ${ }^{264}$ in which the Court invalidated an Oklahoma statute which mandated sterilization for criminals convicted two or more times for felonies involving moral turpitude. ${ }^{265}$ Strictly speaking, Skinner is an Equal Protection Clause case, not a due process case. The Court invalidated the law in question because it forced sterilization upon certain habitual felons convicted of crimes of "moral turpitude" but left other habitual felons untouched. ${ }^{266}$ The Court noted the discriminatory effect of the law, stating:

A clerk who appropriates over $\$ 20$ from his employer's till and a stranger who steals the same amount are thus both guilty of felonies. If the latter repeats his act and is convicted three times, he may be sterilized. But the clerk is not subject to the pains and penalties of the Act no matter how large his embezzlements nor how frequent his convictions. ${ }^{267}$

Skinner clearly intimates that procreation is a fundamental right, since the Court invoked strict scrutiny, ${ }^{268}$ proclaiming that "marriage and procreation are fundamental to the very existence and survival of the [human] race"269 and concluded that, by preventing conception, the law in question interfered with "one of the basic civil rights of man." ${ }^{.270}$

Further elucidation of the fundamental right intimated in Skinner came in Stanley v. Illinois, ${ }^{271}$ in which the Court cited Skinner as setting forth a right to "conceive and to raise one's children," a right the Court described as "far more

CONST. amend. XIV, § 1. A similar Due Process Clause in the Fifth Amendment limits the power of the federal government. U.S. CoNST. amend. V.

262. Meyer, 262 U.S. at 399.

263. See id.

264. 316 U.S. 535 (1942).

265. See id. at 536 .

266. Id.

267. Id. at 538-39.

268. See id. at 541 .

269. Id.

270. Id.

271. 405 U.S. 645 (1972). 
precious ... than property rights."272 Moreover, in Cleveland Board of Education v. LaFleur, ${ }^{273}$ the Court invalidated a restrictive maternity leave policy for teachers and stated that its procreational liberty cases established a "freedom of personal choice in matters of marriage and family life. ${ }^{274}$

Moreover, in a case challenging a broad-ranging Pennsylvania abortion law, Planned Parenthood of Southeastern Pennsylvania v. Casey, ${ }^{275}$ a majority of the Court stated:

Our law affords constitutional protection to personal decisions relating to marriage, procreation, contraception, family relationships, child rearing, and education. . . . These matters, involving the most intimate and personal choices a person may make in a lifetime, choices central to personal dignity and autonomy, [and therefore] are central to the liberty protected by the Fourteenth Amendment. At the heart of liberty is the right to define one's own concept of existence, of meaning, of the universe, and of the mystery of human life. Beliefs about these matters could not define the attributes of personhood were they formed under compulsion of the state. ${ }^{276}$

The Court asserted that an individual's decision whether or not to procreate is included among the liberties protected by the Due Process Clauses of the Fifth and Fourteenth Amendments. ${ }^{277}$ The rationale for protecting such intimate decisions is likewise clear: because individual views on the "mystery of human life" and the "concept of existence" are so likely to vary from individual to individual, the Court believed that regulating such intimate matters "under compulsion of the state" would ineluctably usurp individual liberty. ${ }^{278}$

Taken in its narrowest form, Skinner and its progeny stand for the proposition that married individuals have a fundamental right to coital procreation. ${ }^{279} \mathrm{~A}$ strong case can be made, however, to extend this right to

272. Id. at 651 .

273. $\quad 414$ U.S. 632 (1974).

274. Id. at 639 .

275. 505 U.S. 833 (1992).

276. Id. at 851 (emphasis added).

277. See id.

278. Id.

279. Although the Supreme Court has never explicitly decided the issue, the right of coital procreation likely does not extend to adulterous liaisons. See Mark Strasser, Queer Matters: Emerging Issues in Sexual Orientation Law: Sodomy, Adultery, and Same-Sex Marriages: On Legal Analysis and Fundamental Interests, 8 UCLA WOMEN's L.J. 313, 316 (1998) ("The right to commit adultery is not protected by the Constitution because adultery tends to undermine marriages and destroy families."); see also Poe v. Ullman, 367 U.S. 497, 552-53 (1961) (Harlan, J., dissenting):

The family is not beyond regulation, and it would be an absurdity to suggest either that offenses may not be committed in the bosom of the family or that the home can be made a sanctuary for crime. The right of privacy most manifestly is not absolute. Thus, I would not suggest that adultery, homosexuality, fornication and incest are immune from 
unmarried persons. ${ }^{280}$ Indeed, in Eisenstadt v. Baird, ${ }^{281}$ the Court stated that "[i]f the right of privacy means anything, it is the right of the individual, married or single, to be free from unwarranted governmental intrusion into matters so fundamentally affecting a person as the decision whether to bear or beget a child." 282

Moreover, because all cases decided by the Court thus far have dealt with coital reproduction, it is unclear to what extent, if at all, noncoital forms of reproduction, such as artificial insemination, IVF, or cloning, are constitutionally protected. The Court's language regarding "procreation" and "bear[ing] or beget[ting] a child" is clearly broad enough to encompass noncoital forms of procreation. But since these issues were not before the Court, it is not clear whether we should presume that the fundamental right of procreation is limited to sexual intercourse. Perhaps it means something slightly broader but still not so broad as to encompass cloning, such as any form of sexual procreation (which would include ARTs such as IVF or artificial insemination) but not asexual procreation.

Very little case law exists to help answer these questions because neither the states nor the federal government have prohibited the use of existing ARTs. Moreover, when the government has tried to differentiate between procreation by intercourse and procreation through the use of ARTs, the lower courts have generally upheld the right of individuals to use ARTs. In Cameron v. Board of Education, ${ }^{283}$ for example, the plaintiff, a public school teacher, sued her employer for sexual discrimination, asserting that her contract was not renewed because, as a

criminal enquiry, however privately practiced. So much has been explicitly recognized in acknowledging the State's rightful concern for its people's moral welfare.

Id; Oliverson v. West Valley City, 875 F. Supp. 1465, 1478-85, 1480 (D. Utah 1994) (surveying case law and concluding that "[a]n examination of these decisions shows no support for a conclusion of a constitutional right . . . to engage in adulterous conduct"); accord Chlystek v. Kane, 412 F. Supp. 20, 23 n.7 (W.D. Pa. 1976), rev'd, 540 F.2d 171 (3d Cir. 1976) (" $[T]$ he Pennsylvania legislation [punishing adultery] assailed in the case at bar does not conflict with such a [constitutional] right, but indeed affords it additional protection. The statute is simply a means for protecting the sanctity of marriage, and of deterring disregard for the fundamental obligations of that "basic' civil status."); City of Sherman v. Henry, 928 S.W.2d 464 (Tex. 1996). But see Briggs v. North Muskegon Police Dep't, 563 F. Supp. 585 (W.D. Mich. 1983), aff'd without op., 746 F.2d 1475 (6th Cir. 1984) ("Notwithstanding cases to the contrary, this Court concludes that better logic supports the view which upholds the constitutional right of sexual privacy. Accordingly, the Court is of the opinion that the privacy and associational interests implicated here are sufficiently fundamental to warrant scrutiny of the defendant's act [of firing a police officer for cohabiting with a married woman not his wife] on more than a minimal rationality basis.").

280. See generally Comment, Reproductive Technology and the Procreation Rights of the Unmarried, 98 HARV. L. REV. 669 (1985).

281. 405 U.S. 438 (1972).

282. Id. at 453 (emphasis added).

283. 795 F. Supp. 228 (S.D. Ohio 1991). 
single woman, she had conceived a child using artificial insemination. ${ }^{284}$ More specifically, one of the counts in the plaintiff's complaint asserted that her substantive due process rights had been violated by her termination and alleged that she had a fundamental procreative right to become pregnant through artificial insemination. ${ }^{285}$ The court denied the school board's motion for summary judgment on the substantive due process count, holding that, pursuant to Supreme Court decisions in LaFleur, Eisenstadt, Roe, and Griswold, "[a] woman has a constitutional privacy right to control her reproductive functions. Consequently, a woman possesses the right to become pregnant by artificial insemination."286 Cameron suggests that the fundamental right of procreation is a broad right, granting women "control [over their] reproductive functions," 287 thus including not only a right not to become pregnant ${ }^{288}$ but also the affirmative right to become pregnant, including the use of ARTs such as artificial insemination. The Cameron court's focus thus seems to be the woman's right to control her own body, granting women a zone of reproductive privacy stretching from conception to birth to abortion.

In Goodwin v. Turner, ${ }^{289}$ a federal prisoner filed a petition for a writ of habeas corpus, asserting that the Bureau of Prison's refusal to allow him to provide semen to his wife for the purpose of artificially inseminating her violated his constitutional right of procreation. ${ }^{290}$ The District Court denied his petition, holding that the fundamental right to procreation does not survive incarceration. ${ }^{291}$ The Eighth Circuit affirmed the denial of the habeas petition, but did not reach the issue of whether the Bureau's refusal violated his fundamental right of procreation. ${ }^{292}$ Specifically, the Eighth Circuit concluded that "[e]ven assuming, without deciding, that the exercise of Goodwin's right to procreate is not fundamentally inconsistent with his status as a prisoner, the restriction imposed by the Bureau is reasonably related to achieving its legitimate penological interest."293 The court thus assumed that the Bureau's refusal to allow Goodwin to provide semen to his wife violated his fundamental constitutional right to procreate, but concluded that the Bureau's policy was not subject to the usual strict scrutiny because of the Supreme Court's decision in Washington v. Harper. ${ }^{294}$ In Harper, the Court held that the "proper standard for determining the validity of a prison regulation claimed to infringe on an inmate's constitutional rights is to ask whether

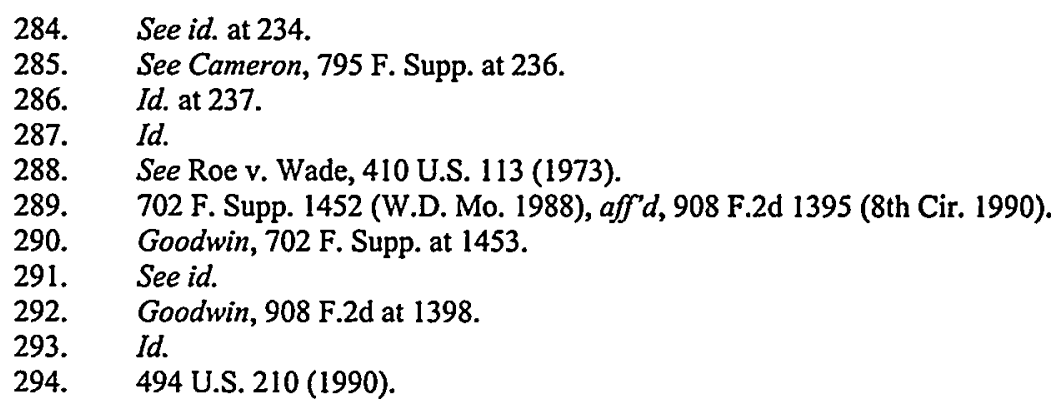


the regulation is "reasonably related to legitimate penological interests." 295 The decision in Goodwin again intimates that appellate courts would find not only that an affirmative right to procreation exists and is fundamental but also that the use of ARTs such as artificial insemination falls within the ambit of such a fundamental right.

The famous "Baby M" case, In re Baby $M, 296$ also strongly intimates that the affirmative right of procreation not only exists but also includes the use of ARTs. In this case, Mr. and Mrs. Stern signed a surrogacy contract with Mary Beth Whitehead. ${ }^{297}$ Ms. Whitehead agreed to be artificially inseminated with Mr. Stern's sperm, to carry the fetus to term, and to relinquish her parental rights to the baby after its birth. ${ }^{298}$ After the baby's birth, however, Whitehead refused to relinquish the baby, and the Sterns brought an action to enforce the contract. ${ }^{299}$ Both the Sterns and Whitehead asserted a constitutional right to custody of the child, the Sterns arguing entitlement grounded in the right of procreation and Whitehead arguing entitlement grounded in the "right of the companionship of her child." $" 300$

The New Jersey Supreme Court held that the surrogacy contract between the Sterns and Whitehead was invalid as a matter of public policy and granted custody to Whitehead as the child's legal mother. ${ }^{301}$ In so doing, the court denied the Stern's procreative liberty assertion and simultaneously refused to address Whitehead's constitutional claim. ${ }^{302}$ In denying the Stern's procreative liberty claim, the court stated that "[t]he right to procreate very simply is the right to have natural children, whether through sexual intercourse or artificial insemination."303 Thus, because Baby M had, in fact, been born, the court concluded that Mr. Stern had not been deprived of his constitutional right to procreate. ${ }^{304}$ The New Jersey Supreme Court believed that the fundamental right of procreation, while it did include the right to use ARTs such as artificial insemination, did not extend to include a right of custody of the biologically related child. ${ }^{305}$

In Lindley $v$. Sullivan, ${ }^{306}$ the plaintiffs adopted a son and soon thereafter applied for Child Insurance Benefits (CIB) that are generally provided to the

295. Id. at 223. The Harper Court made clear that this standard-and not strict scrutiny-is the correct standard to apply, even if the constitutional right infringed is a fundamental one. See id.

296. $\quad 537$ A.2d 1227 (N.J. 1988).

297. Id. at 1234.

298. See id. at 1235 .

299. See id. at 1236-37.

300. Id. at $1238-39$.

301. See id. at 1240-50.

302. See id. at 1253.

303. Id. at 1253 (emphasis added).

304. See id. at 1253-54.

305. See id. at 1254 ("There is nothing in our culture or society that even begins to suggest a fundamental right on the part of the father to the custody of the child as a part of his right to procreate when opposed by the claim of the mother to the same child.").

306. 889 F.2d 124 (7th Cir. 1989). 
disabled and other beneficiaries of the Social Security Act. ${ }^{307}$ The Social Security Administration denied the Lindleys' application for CIB, because the Social Security Act explicitly stated that CIB was not available to parents who adopted children after the beneficiary became entitled to Social Security benefits. ${ }^{308}$ In contrast, parents who conceived children through coitus or ARTs after the beneficiary became entitled to benefits were entitled to CIB. ${ }^{309}$ The Lindleys challenged the disparate treatment between adoptive parents and natural parents, asserting that such disparity violated the Equal Protection Clause. ${ }^{310}$ The Lindleys asserted that the Seventh Circuit should apply strict scrutiny to the law in question, because the disparate treatment between adoptive and natural parents violated the fundamental right to procreation which, they further asserted, included the right to adopt children. ${ }^{311}$ The Seventh Circuit declined the Lindley's invitation to proclaim that the fundamental right to procreation included a right of adoption, ${ }^{312}$ stating that there were "critical distinctions" between adoption and procreation. ${ }^{313}$ More importantly for purposes of this Article, however, in dicta the Seventh Circuit cited Griswold and stated that "the rights to marry and to procreate biologically are older than any state law and, for that matter, older than the Constitution or the Bill of Rights." 314 Thus stated, the court suggested that while the fundamental right of procreation may not reach so far as to entitle an individual to adopt non-biologically related children, it does protect an individual's right to "procreate biologically," which presumably would include the use of ARTs. ${ }^{315}$ The court in Lindley was not, of course, being asked to decide whether ARTs fall within the ambit of the right of procreation. But the court acknowledged that such a right existed and that it was fundamental. ${ }^{316}$ The court further suggested that a critical factor in determining the scope of this fundamental right is biological linkage between parent and child, a linkage that exists with intercourse and ARTs, but not adoption. ${ }^{317}$

One additional case, Lifchez $v$. Hartigan, ${ }^{318}$ squarely presented this issue to a district court: whether the right of procreation included the right to use an ART, specifically, IVF. ${ }^{319}$ The court held that reproductive technology use is constitutionally protected, stating, "It takes no great leap of logic to see that within the cluster of constitutionally protected choices that includes the right to have access to contraceptives, there must be included within that cluster the right to

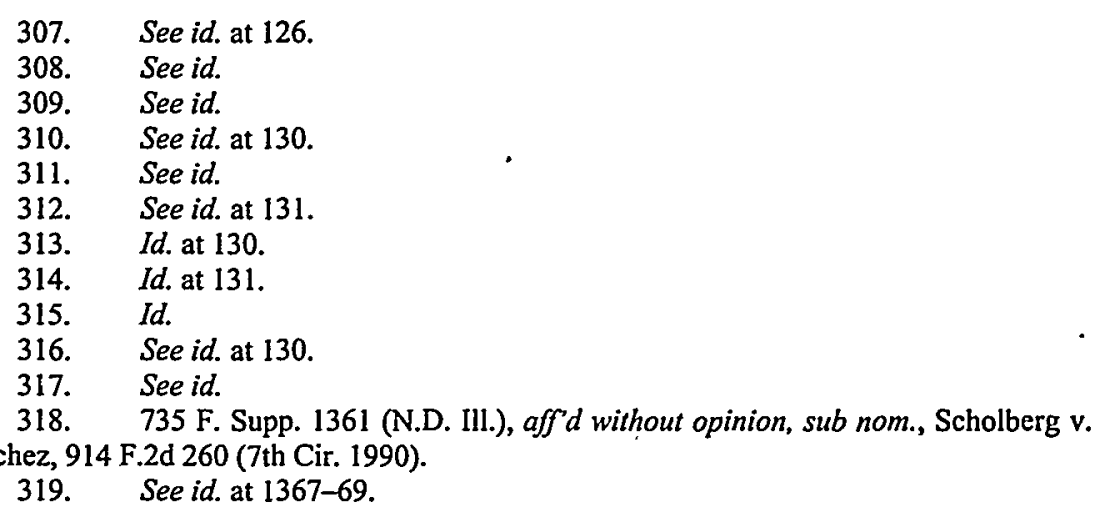


submit to a medical procedure that may bring about, rather than prevent, pregnancy." 320

The Lifchez court's rationale is compelling. Individuals have a right under Griswold v. Connecticut to use contraceptives and a right under Roe $v$. Wade to abort a fetus, both of which indicate a broader right to prevent or terminate pregnancy. Moreover, under Skinner and Eisenstadt, individuals have a right to be free from forced sterilization, which indicates a broader right to bear or beget a child. These cases, viewed as a coherent whole, reveal that the constitutional right protected by the Court thus far is not likely a narrow right to be free from forced sterilization, to obtain birth control, or to obtain an early term abortion. Rather, the right is one of procreational autonomy, the fundamental right to decide whether, when, and how to bear or beget a child..$^{321}$

Because cloning is merely an asexual form of procreation, it is arguably as much a fundamental constitutional right as our right to procreate by either passion or the petri dish. Lori Andrews, however, argues passionately that cloning is "too qualitatively different" from "normal reproduction" and IVF to assume that it falls within the ambit of the constitutional right to procreate. ${ }^{322}$ George Annas likewise argues that cloning should be considered replication rather than reproduction, and therefore falls entirely outside the constitutional right to procreation. $^{323}$

Are such attempts to draw distinctions between cloning and other forms of reproduction valid or merely semantics? It is worth noting that the dictionary definition of the words "reproduction" and "replication" appear to be virtually identical. Reproduction is defined as the act of producing a "counterpart, image, or copy" or the "sexual or asexual process by which organisms generate others of the same kind." "R24 Replication is defined as a "copy," an "echo or reverberation,"or, interestingly enough, "reproduction." 325

320. Lifchez, $735 \mathrm{~F}$. Supp. at 1377.

321. John Robertson uses the phrase "procreative liberty" and argues persuasively that the use of assisted reproductive technologies such as cloning fall within its ambit. See Robertson, supra note 21, at 1388-92; see also JOHN A. ROBERTSON, CHILDREN OF CHOICE: FREEDOM AND THE NEW REPRODUCTIVE TECHNOLOGIES 22-42 (1994).

322. Andrews, supra note 69, at 666.

323. See Annas, supra note 3, at 80; accord Annas, supra note 21, at 254.

324. THE AMERICAN HERITAGE DictionaRY 1050 ( $2 \mathrm{~d}$ ed. 1985).

325. Id. at 1048-49. Another term that might be used, duplication, is defined as the "act or procedure of duplicating." THE AMERICAN HERITAGE DICTIONARY 430 ( $2 \mathrm{~d}$ ed. 1985). "Duplicate" is then defined as "[i]dentically copied from an original" or "an identical copy; duplicate" or "something that corresponds exactly to something else ...." Id. It should be noted that children created by cloning are not identical copies of their DNA donors-either genetically, socially, or psychologically. The presence of mitochondrial DNA of the egg donor means that a child created by cloning will not be an exact genetic match to the DNA donor (unless, of course, the DNA donor is also the egg donor). And because the child created by cloning would have very different historical, social, and psychological experiences from the DNA donor, the categorization of such a child as an "identical" copy is even further attenuated. 
Semantics aside, however, the salient inquiry is whether reproduction by cloning is, as Lori Andrews asserts, qualitatively different from reproduction by other existing means. ${ }^{326}$ This inquiry collapses into the second prerequisite necessary for finding that an asserted liberty interest is protected by substantive due process: namely, an examination as to whether the asserted interest is "deeply rooted" in the nation's history and traditions. ${ }^{327}$ In Palko v. Connecticut, ${ }^{328}$ the Court implied that in order for a right to be considered a fundamental liberty interest under the Due Process Clause, it must be "so rooted in the traditions and conscience of our people as to be ranked fundamental." 329 Moreover, the Court stated that the asserted right must be "implicit in the concept or ordered liberty ... [such that] neither liberty nor justice would exist if [it were] sacrificed." ${ }^{330}$

Where the asserted right is itself "new," i.e., where it has not existed long enough for it ipso facto to be historically and traditionally considered fundamental to liberty and justice, Justice Scalia has suggested that the right will not be barred from consideration as a protected liberty interest; rather, the Court in such an instance should "refer to the most specific level at which a relevant tradition protecting, or denying protection to, the asserted right can be identified." ${ }^{\text {"331 }}$ Since the use of ARTs is a relatively recent phenomenon, and therefore has not had enough time to become historically or traditionally deeply rooted in our society, Justice Scalia's suggested analytical framework would have us look to the most specific level at which a relevant tradition protecting the asserted right to use ARTs has been identified. This level would, of course, be the line of cases previously discussed which appear to acknowledge not only a fundamental right not to create, but also, more broadly, an affirmative right to have biological children of one's own. The Court's goal, therefore, should be to determine whether the use of ARTs falls within this fundamental right of procreation.

Assuming arguendo that there is a protected liberty interest of adults to engage in sexual intercourse for procreative purposes, the question becomes whether this liberty interest extends to the use of ARTs. As an initial observation, procreation by ARTs shares one fundamental characteristic with procreation by intercourse: the result, if the process is successful, is a child with whom at least one of the participants has a biological link..$^{332}$ It is also worth noting that the use of ARTs has never been banned by any state, despite widespread horror and often, disgust. Artificial insemination, particularly artificial insemination by donor

326. See Andrews, supra note 69 , at 666 .

327. Washington v. Glucksberg, 521 U.S. 702, 720 (1997).

328. 302 U.S. 319 (1937).

329. Id. at 325 .

330. Id. at 325-26. The Glucksberg Court reaffirmed these principles in 1997, citing this language from Palko with approval. See Glucksberg, 521 U.S. at 720.

331. See Michael H. v. Gerald D., 491 U.S. 110, 127-28 n.6 (Scalia, J.) (plurality opinion).

332. In the context of intercourse and existing ARTs such as artificial insemination and IVF, two individuals will have a biological link with any resulting child. In the context of cloning, by contrast, only one individual, the DNA donor, will have a biological link with any resulting child. 
("AID"), was, until relatively recently, universally condemned. A book published in 1934 described AID as an "outlandish" idea devoid of "tact, decency, and moral feeling." ${ }^{\text {333 }}$ Early case law mirrored this condemnation, with several courts concluding that children born as a result of AID were illegitimate, the product of adultery. ${ }^{334}$

Most of the opposition to artificial insemination stemmed from religious objections. The Catholic Church, for example, opposes artificial insemination if the sperm is produced via masturbation (which it usually is), and therefore permits it only if the sperm is obtained from the husband using needle aspiration rather than masturbation. ${ }^{335}$ The use of donor sperm for artificial insemination is altogether prohibited by the Catholic Church on the grounds that it is adulterous. ${ }^{336}$ Many Jewish theologians share these concerns, opposing AID, inter alia, on the grounds that it would reduce a woman's need for marriage and reduce the role of men to that of "stud farming." ${ }^{\text {"337 }}$ In 1960, a report by the British Feversham Committee on Human Artificial Insemination concluded that AID posed such serious emotional dangers to the sperm donor, impregnated woman, her husband, and the resulting child that it should not be considered an ethically acceptable reproductive option under any circumstances. ${ }^{338}$ Another common objection is that AID may pose a threat to genetic diversity if individuals are allowed to donate sperm without limitation. ${ }^{339}$ By 1980 , the negative image of AID persisted, one commentator opining that AID posed serious psychological risks to the husband whose wife was inseminated by donor sperm, concluding, "The physician is

333. Sherman Elias \& GeORge J. ANNAS, Reproductive Genetics \& The LAW 223-24 (1987) (citing H. ROHLEDER, TeSt Tube Babies: A History OF THE ARTIfiCIAL IMPREGNATION OF HUMAN BEINGS (1934)).

334. See Doornbos v. Doombos, 139 N.E.2d 844 (Ill. 1956); Gursky v. Gursky, 242 N.Y.S.2d 406 (Sup. Ct. 1963); Orford v. Orford, 49 O.L.R. 15 (1951); see also Laurelle H. Kinney, Legal Issues of the New Reproductive Technologies, 52 CAL. ST. BAR J. 514, 514-15 (1977). This early consideration of children conceived by AID as illegitimate has now given way to a presumption that a child conceived by AID with the husband's consent during marriage is the legitimate offspring of the husband and wife. See HOMER H. CLARK, JR., 1 THE LAW OF DOMESTIC RELATIONS IN THE UNITED STATES 284 (2d ed. 1987) (noting that most states follow the Uniform Parentage Act, which provides that a child conceived by AID during marriage is to be treated as the natural child of the husband, provided both husband and wife have provided written consent to the procedure).

335. See FrOMER, supra note 27, at 265.

336. See id. The Protestant churches do not appear to deem the use of artificial insemination by donor to be adulterous. Id. at 266; see also ROBERT A. MCCORMICK, How BRAVE a NEW WORLD? DILEMMAS IN BIOETHICS 312-13 (1981).

337. See MCCORMICK, supra note 336 , at 314.

338. See Judith F. Daar, The Future of Human Cloning: Prescient Lessons From Medical Ethics Past, 8 S. CAL. INTERDIS. L.J. 167, 171 (1998).

339. See Barty R. Furrow et al., Health law: Cases, Materials and ProBlems 953 (3d ed. 1997). The American Society for Reproductive Medicine (formerly the American Fertility Society) has attempted to address this concern by recommending that sperm from any single donor should not be used to create more than 10 offspring. See AFS Report, supra note 153, at 44S-45S. 
saying to the male partner that he is inadequate to properly inseminate his wife whereas the physician, with his technology, can do the job better." 340

IVF initially did not fare much better in its quest for public acceptance. ${ }^{341}$ Many objected to the procedure on the grounds that it caused the creation of too many waste embryos. ${ }^{342}$ Others worried that the procedure posed serious risks of birth defects to the embryo ${ }^{343}$ and both psychological and physical risks to the woman and resulting child. ${ }^{344}$ Still others labeled IVF "morally irresponsible"345 on grounds that its inherent segregation of procreation from marital sex "violates the reverence due to human life in its generation." ${ }^{\text {"346 }}$ In 1975, three years before the

340. Hilgers, supra note 26 , at $42-43$.

341. See SILVER, supra note 42, at 76 ("When news of [IVF] development by Steptoe and Edwards reached the media during the 1970s, there were editorials calling for the abandonment of all further research on 'test tube babies.' And when the first IVF baby was born, most Americans found the notion so bizarre that they wouldn't think about using it themselves."); see also AFS Report, supra note 153, at 36S (listing common ethical reservations regarding IVF).

342. See Hilgers, supra note 26 at 44 (writing in 1980-two years after Louise Brown's birth-that "[n]obody knows for sure how many conceptions occur for every successful implantation. However, the overwhelming majority of early morulae would die because of unsuccessful implantation."); id. at 45-46 ("There is little question that the procedure causes extensive waste of preimplantation human embryos. This has created a considerable amount of controversy."); see also MCCORMICK, supra note 336, at 322.

343. See, e.g., Leon R. Kass, Babies By Means of in Vitro Fertilization: Unethical Experiments on the Unborn?, 285 NEW ENG. J. MED. 1174 (1971) (calling for a voluntary moratorium on the use of IVF "[b]ecause the new procedures for in vitro fertilization and laboratory culture of human embryos probably carry a serious risk of damage to any child so generated, there appears to be no ethical way to proceed"); William E. May, Reverencing Human Life in its Generation, in THE NEW TECHNOLOGIES OF BIRTH AND DEATH: MEDICAL, LEGAL AND MORAL DIMENSIONS 56, 67-68 (1980).

344. See FROMER, supra note 27, at 272-73 ("Undoubtedly there is considerable risk to the blastocyst (and some minimal risk to the woman) in IVF, but it is difficult, if not impossible, to assess precisely what those risks are."); see also EUGENE B. BRODY, BIOMEDICAL TECHNOLOGY AND HUMAN Rights 90 (1993) ("Although there is no evidence to that effect, it cannot yet be definitively stated whether or not repeated [egg retrieval] interventions will have unfavorable effects on the anatomy and functioning of the reproductive organs [of the woman]."); MCCoRMICK, supra note 336, at 323-24.

345. See May, supra note 343, at 61:

Of more immediate and pressing concern here are the views of those who believe that married couples may, if necessary, rightly make use of such technologies as artificial insemination and in vitro fertilization in order to generate new human life. I believe that a true understanding of marriage, of the marital act, and of the relationship between marriage and the generation of human life will show that such practices are morally irresponsible. Moreover, once this understanding is grasped, it should be clear that artificial insemination by a vendor and in vitro Id. fertilization ought to be legally proscribed.

346. Id. at 64; see also Constance Holden, The Vatican Weighs In: Statement on In Vitro Fertilization, SCIENCE, Mar. 20, 1987, at 1455 ("The recent Vatican 'instruction' condemning in vitro fertilization ... explicitly codifies what the Catholic church has said 
birth of Louise Brown, ${ }^{347}$ the U.S. Department of Health, Education, and Welfare issued a moratorium on the use of federal funds to support IVF until such time as an Ethics Advisory Board ("EAB") could make recommendations regarding the ethical use of the procedure. ${ }^{348}$ It was not until 1979 that the EAB issued its report and recommendations, concluding that IVF is "acceptable from an ethical standpoint,"349 and recommending federal funding of IVF research, provided certain guidelines were followed. ${ }^{350}$ Although the U.S. Department of Health and Human Services adopted the EAB's recommendations and guidelines, the EAB was soon thereafter disbanded, leaving no governmental body to review IVF research funding proposals for conformity with the federal guidelines and creating a de facto moratorium on federal funding that continues today. ${ }^{351}$

Today, IVF appears to enjoy a strong measure of public acceptance, ${ }^{352}$ with more than 150,000 children born through the procedure thus far, and an estimated half million born globally by $2005 .{ }^{353}$ A recent series of statewide meetings conducted by medical ethicists at Michigan State University and the University of Michigan revealed that sixty to seventy percent of individuals believed that "parents should be morally free to pursue whatever ARTs are

all along: that the only right way to have a baby is through normal sexual intercourse within the context of marriage.").

347. Louise Brown was the first 'test tube baby' conceived and born using IVF. She was born on July 25,1978 . See SILVER, supra note 42, at 67-68.

348. See Hilgers, supra note 26, at 46; see also Colin Norman, IVF Research Moratorium to End? Federal Support for Research Involving In Vitro Fertilization, SCIENCE, July 22, 1988, at 405.

349. Hilgers, supra note 26 , at 46 .

350. The guidelines included, inter alia, a requirement of informed consent for gamete donors, a limitation on the in vitro development of embryos beyond 14 days, and restricting the procedure to married couples. See FROMER, supra note 27, at 273; SMITH, supra note 29 , at 142, n. 47 .

351. Norman, supra note 348 , at 405 ; ElIAS \& ANNAS, supra note 333, at 237. As of the time this Article was written, it was reported that the National Bioethics Advisory Commission was expected to issue a report in the summer of 1999 recommending that the federal moratorium on human embryo research be lifted. See Elizabeth Neus, Ethics Commission May Weigh in on Funding Human Embryo Work, GANNETT NEWS SERV., June 30, 1999, at ARC.

352. See Daar, supra note 338 , at 178 (concluding that "overall it seems that IVF has had positive influence on our society, enabling otherwise infertile couples to procreate safely. . . . And, like AID, IVF is practiced in this country amid little governmental regulation, reflecting either overall approval or a lack of consensus on the need to curb the practice"); see also Victor Cohn, Catholic Hospitals Balancing Medical Advances and Papal Values, WASH. POST, June 9, 1987, at Z12 (reporting that a Gallup poll taken in 1978-the year of Louise Brown's birth-revealed that $60-75 \%$ of Americans support the use of in vitro fertilization); Holden, supra note 346, at 1455 (stating that seven polls indicate that $60-74 \%$ of Americans support in vitro fertilization within the context of marriage, including $56 \%$ support among Catholics).

353. See SILVER, supra note 42, at 69. 
available to avoid the birth of a child with a serious genetic disorder." ${ }^{3354}$ Such overwhelming public support suggests that Americans consider the use of ARTsat least in the context of avoiding genetic disease of offspring-to be a fundamental aspect of liberty.

Experience with artificial insemination and IVF indicate that public acceptance of ARTs comes slowly. But the important point for a substantive due process analysis is that despite an initial lack of public acceptance, neither the state nor federal governments have rushed to ban such procedures. This history and tradition of tacit legal acceptance may indicate that Americans consider the use of ARTs to be fundamental to liberty and justice, despite the fact that social acceptance has been slow in certain religious sectors of society. As Justice Scalia stated in Michael H. v. Gerard $D .{ }^{355}$ for an asserted liberty interest to obtain protection under the Due Process Clause, it not only must be "fundamental" but also must be an interest which has been "traditionally protected by our society."356 Such protection, moreover, "need not take the form of an explicit constitutional provision or statutory guarantee, but it must at least exclude ... a societal tradition of enacting laws denying the interest." ${ }^{357}$ In the context of ARTs, therefore, the absence of a tradition denying the use of ARTs would be a relevant factor in favor of recognizing substantive due process protection. ${ }^{358}$

If reproduction using ARTs is indeed within the ambit of protected activity under substantive due process, cloning may also be protected, depending upon how one characterizes cloning. If cloning is viewed as merely another ART, then cloning would be constitutionally protected. If, on the other hand, cloning is viewed as qualitatively distinct from existing ARTs, then cloning would not be constitutionally protected by substantive due process.

The most obvious difference between reproduction by cloning and reproduction by existing ARTs is that the former is asexual, whereas the latter is sexual. Thus, cloning does not require the unification of sperm and egg, whereas other ARTs do. As a normative matter, should this distinction be legally meaningful? On the one hand, one might argue that because cloning does not require the unification of sperm and egg, it has the potential to undermine the

354. LeONard M. Fleck, Genome TeChNology and Reproduction: Values AND PUBLIC POLICY (1996) (Executive Summary, Item No. 6); see also SILVER, supra note 42 , at 34.

355. 491 U.S. 110, reh' $g$ denied, 492 U.S. 937 (1989).

356. Id. at 122 .

357. Id. at $123 \mathrm{n} .2$ (emphasis in original).

358. Contrast the situation in Bowers v. Hardwick, where the Court, in holding that a law criminalizing sodomy was not violative of substantive due process, noted that at the time the Fourteenth Amendment was ratified, all but five of the 37 states criminalized sodomy, and that 24 states and the District of Columbia continued to do so at the time of the Court's decision in the mid-1980s. See 478 U.S. 186, 192-93, reh'g denied, 478 U.S. 1039 (1986). The Court concluded that given the historical and traditional legal prohibition against sodomy, "to claim that a right to engage in such conduct is 'deeply rooted in this Nation's history and tradition' or 'implicit in the concept of ordered liberty' is, at best, facetious." Id. at 194. 
importance of heterosexual relations and the traditional family structure. Of course, one can make equally strong arguments that such fears are unfounded. ${ }^{359}$ But even assuming arguendo that they are true, the salient question is whether cloning holds a greater potential to undermine heterosexual relations and the traditional family structure than existing ARTs, such as artificial insemination and IVF.

As has already been demonstrated, similar concerns about the destruction of marriage and family were voiced at the incipiency of artificial insemination and IVF. ${ }^{360}$ And while some may argue that heterosexual relations and the traditional family structure have been weakened since the advent of such ARTs, it would be virtually impossible to demonstrate a causal relationship. Numerous other societal changes and factors have contributed to the changing conception of male-female relations and family structure. More fundamentally, perhaps, artificial insemination and IVF both permit individuals outside of marriage to procreate (as does sexual intercourse) and to do so within marriage using the genetic material of third parties (as does adultery). True, cloning would allow homosexual men to procreate using a surrogate mother or homosexual women to procreate without the use of a surrogate mother, but then again, so do existing ARTs. Cloning thus appears to be no more of a threat to heterosexual relations or family integrity than do existing ARTs, if they can be said to constitute a threat at all.

Of course, if cloning falls within the ambit of procreational liberty, it is important to note that such liberty appears to extend only to individuals who either bear (i.e., gestate) ${ }^{361}$ or beget (i.e., produce) $)^{362}$ a child, that is, to those who traditionally would have been considered the mother and father of the child. In the context of human cloning, the "bearer" of the child would be the gestational mother, and the "begetter" would be the DNA donor. Thus, an individual who wished to use his/her own DNA to replicate himself via cloning would have a constitutional right to do so, as would a woman who wished to gestate a fetus with which she has no genetic relationship. ${ }^{363}$ If the donor and the individual who intends to gestate are the same individual, such individual (necessarily a woman) would obviously be the exclusive holder of the procreational right.

359. See infra Part V.A.

360. See supra notes 345-346 and accompanying text.

361. To "bear" a child is generally understood as "to give birth to" that child. See The American Heritage Dictionary 164 (2d ed. 1985). Thus, the one who "bears" a child would necessarily be the woman who gestates the child in her womb.

362. "Beget" is defined as "to father; sire" or "to cause to exist; produce." THE AMERICAN HERITAGE Dictionary 168 (2d ed. 1985). Thus, the one who "begets" a child in the cloning context would be the DNA donor, who could be either male or female.

363. The gestational (i.e., surrogate) mother may have some small genetic relationship to the fetus if she donated the enucleated egg, as some mitochondrial DNA may be present. See NBAC REPORT, supra note 8, at 19-20. The surrogate mother would also, of course, continue to have a constitutional right to abort the fetus prior to the point of viability. See Planned Parenthood of Southeastern Pa. v. Casey, 505 U.S. 833 (1992); see also infra Part V.B. 
But what if neither of these individuals (the donor nor the gestational mother) plays a role in rearing the child? In other words, what if Albert donates his DNA, Betty agrees to gestate the fetus, and when Albert II is born, Albert and Betty relinquish all parental rights to Charlene and David, who then raise him? ? $^{364}$ As a normative matter, should the procreational desires of Albert and Betty receive constitutional protection? John Robertson makes a strong argument that neither Albert nor Betty should enjoy a constitutional right to procreation if they have no intent to rear the child. ${ }^{365}$ He calls this non-rearing situation reproduction tout court (without more) ${ }^{366}$ and concludes that, without an intention to rear, individuals such as Albert and Betty "treat children like fungible commodities produced for profit without regard to their well-being." ${ }^{\text {"367 }}$ Such profit-seeking and commodification of human children is thus undeserving of constitutional protection. $^{368}$

As a normative matter, Robertson's analysis has strong appeal. Nonetheless, it can be argued that the Albert-Betty situation is not qualitatively different from ordinary adoptions. While existing procreative liberty jurisprudence would not provide the adoptive parents, Charlene and David, with a constitutional right to obtain a child to whom they have no genetic or gestational link, ${ }^{369}$ it does suggest that both Albert and Betty would enjoy procreative rights in this situation.

364. This hypothetical assumes that neither Albert nor Betty engage in childselling, which is prohibited in every state. See, e.g., ARIZ. REV. STAT. $§ 13-3625$ (1999); COLO. REv. STAT. § 18-6-402 (1999); WASH. Rev. CODE § 9A.64.030 (1999).

365. See ROBERTSON, supra note 321, at 1398-99. Robertson concludes that "[a]ny right to clone by persons who do not intend to rear would have to derive from the right of those who end up rearing." Id. at 1399. Robertson likewise concludes that the adoptive parents, e.g., Charlene and David, have no independent procreational rights absent a gestational or biological link to the child. See id. at $1399 \&$ n.116 "The right to acquire children for rearing might be important, but it is not reproductive when there is no genetic or gestational involvement; at present it has no moral or constitutional standing as reproductive activity.").

366. See id. at 1400 n.119. Robertson acknowledges that "[t]he courts have not yet determined whether engaging in or avoiding reproduction tout court deserves the same protection that more robust or involved forms of reproduction have." Id.

367. Id. at 1399.

368. Id. Robertson states, "The right to acquire children for rearing might be important, but it is not reproductive when there is no genetic or gestational involvement; at present it has no moral or constitutional standing as reproductive activity." Id. at 1399 n.116. This appears to mirror my conclusion above that an adoptive couple, e.g., Charlene and David, do not have an independent constitutional right to the conception or adoption of Albert II. However, Robertson appears to disagree with the conclusion that Albert and Betty have constitutional rights since they do not intend to rear the child. See, e.g., id. at 13991400 (stating that the DNA donor would have little or no procreative interest "unless she undertook to rear the resulting child"); $i d$. at 1401 (asserting that "cloning oneself with no rearing intended would have no independent claim to be an exercise of procreative liberty. If it is protected at all, cloning oneself would be derivative of the right of the couple or individual who then gestate and rear the cloned child").

369. See, e.g., Lindley v. Sullivan, 889 F.2d 124 (7th Cir. 1988) (holding that adoption does not fall within procreative liberty). 
Specifically, Albert (as the DNA donor with a genetic link to the child) has the right to "beget" the child, and Betty (the gestational mother) has the right to "bear" the child; hence, both may have valid parental claims on the child (Albert II) if they wished to assert them. ${ }^{370}$ If Albert and Betty opt to relinquish knowingly and voluntarily their parental rights to Albert II, Charlene and David should be able to adopt Albert II in accordance with state adoption laws.

It is also important to note that, if one accepts this latter view of procreational liberty, the motives behind having the child are, at least legally speaking, irrelevant. Thus, a couple who creates a child via cloning for the purpose of "replacing" a child who died of cancer is entitled to do so, regardless of how one may view the morality or ethics of their motives. ${ }^{371}$ Indeed, there is very little (if any) condemnation of parental motives when the "replacement" child is conceived through sexual methods such as coitus or IVF. Even a couple who decides to reproduce, sexually or asexually, in order to obtain a closely matched kidney to transplant to their oldest child dying of kidney disease is generally entitled to do so provided no net harm results to the second child, ${ }^{372}$ though many may question the moral or ethical propriety of their decision.

The reasons motivating the birth of any child, regardless of how the child is conceived, are complex and not always morally or ethically acceptable to others. Analogously, the motives behind a woman's decision to abort are complex and not always morally or ethically acceptable to others. A woman may, for example, choose to abort because she does not like the sex of the child, because the child will interfere with her ability to have a "good time," or because she is simply not emotionally or financially ready for parenthood. None of these motivations,

370. See, e.g., In the Matter of Baby M, 537 A.2d 1227 (N.J. 1988).

371. Robertson appears to agree that the motive behind the decision to clone one's own existing children would not affect its status as constitutionally protected activity. ROBERTSON, supra note 321, at 1393:

The parents' precise motive for cloning and subsequent transfer to the uterus will not affect the reproductive nature of their endeavor. Whether they simply want a second child like the first, want a second child who could be a source of tissue or organs, or want to replace a dead or dying child with one with its genes, they are engaged in reproduction because another child of their genes, whom they will gestate and rear, will be born.

Id.

372. In the situation involving an incompetent (such as a minor), courts generally use a cost/benefit analysis and allow donation provided the benefits to the minor outweigh the risks. See, e.g., Strunk v. Strunk, 445 S.W.2d 145 (Ky. 1969) (holding an incompetent, mentally retarded brother could be used as kidney donor because physical harm from donation would be outweighed by psychological benefit of having brother live); see also ROBERTSON, supra note 321, at 1420; Charles H. Baron et. al., Live Organ and Tissue Transplants from Minor Donors in Massachusetts, 55 B.U. L. REV. 159, 178-81 (1975) (describing application of the "best interests test" used in such situations). In his book, The Human Body Shop, author Andrew Kimbrell estimates that between 50 and 100 couples have conceived in order to provide tissue for transplantation to an existing child. See Barbara Ehrenreich, The Economics of Cloning, TIME, Nov. 22, 1993, at 86. 
regardless of how repugnant they might be, will affect her constitutional right to abort the fetus until the point of viability. ${ }^{373}$ Indeed, unless we are prepared to institute "mind police" to enforce the appropriate moral or ethical standards for conceiving a child, there is no place in the law of procreational liberty for distinctions based upon the often inchoate and questionable motivations of parents. ${ }^{374}$

\section{The Equal Protection Clause}

Another constitutional provision implicated by a legislative ban on human cloning is the Equal Protection Clause, which, in general terms, prohibits the government from invidiously discriminating against similarly situated persons. ${ }^{375}$ It is well settled that a law may violate the Equal Protection Clause if the law infringes upon a fundamental right. ${ }^{376}$ In Skinner v. Oklahoma, ${ }^{377}$ the Supreme Court struck down an Oklahoma law requiring forced sterilization of

373. See Planned Parenthood of Southeastern Pa. v. Casey, 505 U.S. 833 (1992) (establishing a right to abort until the point of fetal viability).

374. In this respect, Robertson's analytical approach to procreative liberty is likely to be unenforceable. By hinging the constitutional right to procreation upon the intent of the relevant parties to rear the child, Robertson creates an analytical framework that would grant constitutional protection to those who "intend" to rear the resulting child, but not to those who do not so intend. The difficulty, of course, is that it is often difficult to gauge with any degree of precision what individuals "intend" to do when conception occurs. Smith, for example, may initially desire to donate her DNA for cloning but not intend to rear the child. Presumably, Robertson would conclude that Smith does not enjoy an independent constitutional liberty to procreate under such circumstances. See ROBERTSON, supra note 321 , at 1401 ("[C]loning oneself with no rearing intended would have no independent claim to be an exercise of procreative liberty."). On the other hand, Smith may initially decide to donate her DNA for cloning for the purpose of rearing the resulting later-born twin, but upon the child's birth, change her mind and decide to put the child up for adoption. Under such circumstances, Robertson's intent-based analysis would appear to lead to the conclusion that Smith would enjoy an independent constitutional right to cloning, even though the child is ultimately raised by adoptive parents. Indeed, any other conclusion would mean that Smith would have no constitutional right to procreation and would therefore potentially be subject to laws regulating such behavior, including criminal or civil penalties. Precisely because determining ab initio what Smith intended is so difficult (if not impossible), Robertson's analytical framework, although normatively compelling, is pragmatically unenforceable.

375. See, e.g., City of Clebume v. Clebume Living Ctr., Inc., 473 U.S. 432, 439 (1985); Plyler v. Doe, 457 U.S. 202, 216 (1982); F.S. Royster Guano Co. v. Virginia, 253 U.S. 412, 415 (1920). The Equal Protection Clause of the Fourteenth Amendment, by its own terms, only applies to action by state and local governments. If, however, the federal government were to classify individuals in a manner contravening equal protection, such action would violate the Due Process Clause of the Fifth Amendment. See Bolling v. Sharpe, 347 U.S. 497 (1954).

376. See, e.g., Boddie v. Connecticut, 401 U.S. 371 (1971) (access to courts); Shapiro v. Thompson, 394 U.S. 618 (1969) (interstate travel); Harper v. Virginia Bd. Elections, 383 U.S. 663 (1966) (voting).

377. 316 U.S. 535 (1942). 
certain convicted habitual criminals. ${ }^{378}$ As discussed earlier in the context of substantive due process, ${ }^{379}$ the Skinner Court held that the right of procreation was a "fundamental" right; ${ }^{380}$ hence, the sterilization law, which denied the fundamental right of procreation, was subject to strict scrutiny ${ }^{381}$ and invalid. ${ }^{382}$ From Skinner, therefore, one can surmise that if the fundamental right of procreation includes cloning, ${ }^{383}$ a law banning human cloning would be subject to strict scrutiny and would likely violate the substantive components of both the Due Process and the Equal Protection Clauses.

If a law does not infringe upon a fundamental right, e.g., if cloning does not fall within the fundamental right of procreation, an alternative equal protection analysis is available. Under this analysis, the first step is to identify the classification created by the law which, in turn, will reveal the appropriate level of scrutiny to be applied by the court. The class of individuals that would be singled out by a cloning ban would be those who wish to procreate by cloning. ${ }^{384}$ They are "similarly situated" to another class of individuals who are unaffected by a cloning ban, namely, those who wish to procreate using sexual means such as coitus or existing ARTs. Both classes of individuals are a subset of a larger class of individuals who want to procreate, to have children of their own. The question for equal protection analysis is whether it is permissible to discriminate amongst these two classes, i.e., between those who wish to procreate asexually and those who wish to procreate sexually.

Discrimination based upon the manner by which an individual wishes to procreate does not implicate any classifications identified by the Court as "suspect" (e.g., race or national origin); thus, strict scrutiny would not be required ${ }^{385}$ Likewise, classification based upon the manner of procreation does not fall within any established classifications triggering intermediate scrutiny, such as gender ${ }^{386}$ and illegitimate children. ${ }^{387}$ Thus, an equal protection challenge to a ban on human cloning would likely be subject to rational basis review and upheld if the law is rationally related to a legitimate government purpose. ${ }^{388}$

378. See id. at 536.

379. See supra Part IV.B.

380. Skinner, 316 U.S. at 541.

381. See id.

382. Id. at $541-43$.

383. See supra Part IV.B.

384. Most individuals who can do so appear to prefer to reproduce the "oldfashioned way," i.e., coitally. So in general, the class of persons who wish to reproduce noncoitally will be infertile heterosexual couples. Homosexuals would also be included in this class, since many who wish to procreate may also prefer to procreate noncoitally.

385. See Korematsu v. United States, 323 U.S. 214, 216 (1944).

386. See Craig v. Boren, 429 U.S. 190, 197 (1976).

387. See Clark v. Jeter, 486 U.S. 456, 461 (1988).

388. See, e.g., Pennell v. City of San Jose, 485 U.S. 1, 14 (1988); Hodel v. Indiana, 452 U.S. 314, 331 (1981).

Social and economic legislation . . . that does not employ suspect classifications or impinge on fundamental rights must be upheld against equal protection attack when the 
Although concluding that a rational basis review applies means that the law in question usually will be upheld, there have been exceptions. ${ }^{389}$ For example, in City of Cleburne v. Cleburne Living Center, the Court applied the rational basis test to invalidate a zoning ordinance that effectively prevented the operation of a group home for mentally disabled individuals by requiring a special use permit. ${ }^{390}$ The City of Cleburne offered numerous justifications for its ordinance, including opposition from nearby homeowners, proximity to a junior high school, an excessive number of occupants, and location of the proposed home in a flood plain. ${ }^{391}$ The city's failure to apply the same rules to similar dwellings such as nursing homes and hospitals indicated that the city's purpose behind enacting the ordinance was based upon prejudice against the mentally disabled. ${ }^{392}$ Thus, the Court rejected all of the proffered justifications for the ordinance, concluding it did not serve a legitimate governmental purpose. ${ }^{393}$

Employing similar reasoning, in Romer v. Evans ${ }^{394}$ the Court invalidated the Colorado Constitution's Amendment 2, an initiative that repealed all state and local laws prohibiting discrimination against homosexuals and bisexuals and prohibited all such future anti-discrimination laws. ${ }^{395}$ The State of Colorado defended Amendment 2 on grounds that it furthered public mores ${ }^{396}$ a justification that traditionally has been considered legitimate in equal protection challenges. ${ }^{397}$ The Supreme Court rejected Colorado's justification for Amendment 2, concluding that there was no legitimate purpose for a law denying homosexuals and bisexuals legal protections obtained by them through the political process. ${ }^{398}$ Thus, since the only apparent purpose behind Amendment 2 was "animosity toward the class of persons affected," the Court concluded that the law failed the rational basis test. ${ }^{399}$

In the context of a ban on human cloning, the first step in applying the rational basis standard would be to determine what is the purpose or end sought to be achieved by the law in question. Proponents of banning human cloning would likely argue that the purpose of such a law would be the prevention of

legislative means are rationally related to a legitimate government purpose. Moreover, such legislation carries with it a presumption of rationality that can only be overcome by a clear showing of arbitrariness and irrationality:

Id.

389. See, e.g., Romer v. Evans, 517 U.S. 620, 635 (1996); Allegheny Pittsburgh Coal Co. v. County Coal Comm'n, 488 U.S. 336, 343 (1989); City of Cleburne v. Cleburne Living Ctr., Inc., 473 U.S. 432, 450 (1985).

390. See City of Cleburne, 473 U.S. at $446,450$.

391. See id. at 448-49.

392. See id. at 447-50.

393. See id.

394. 517 U.S. 620 (1996).

395. See id. at 635-36.

396. See id. at 635 .

397. See, e.g., McGowan v. Maryland, 366 U.S. 420 (1961) (upholding state law requiring businesses to be closed on Sundays).

398. See Romer, 517 U.S. at 635.

399. Id. at 634. 
psychological or physical harm and/or the preservation of marriage or the traditional family structure. ${ }^{400}$ While one may reasonably question whether a ban on human cloning would, in fact, prevent such harms, ${ }^{401}$ they are nonetheless legitimate ends of governmental regulation. ${ }^{402}$

Once a legitimate end has been identified, the next step is to ask whether the means chosen to effectuate those ends are "reasonable in light of [the law's] purpose." ${ }^{\text {403 }}$ Thus, the question becomes whether enacting a total ban on human cloning is reasonable to effectuate the legitimate goals of furthering public safety and/or public morality. As an initial matter, a ban on human cloning would appear to be significantly under-inclusive, since it would not prohibit the use of other ARTs that arguably present the same risks of eroding traditional family structures ${ }^{404}$ and causing physical or psychological harm. ${ }^{405}$ Such underinclusiveness is, however, often tolerated by the Court under the rationale that the government "may take one step at a time, addressing itself to the phase of the problem which seems most acute to the legislative mind." of under-inclusion, it appears likely that the government could opt to ban human cloning based on a judgment that cloning presents a more "acute" problem than do other ARTs.

A law banning human cloning would also likely be significantly overinclusive, as it would ban all human cloning, thereby covering more individuals than needed in order to accomplish the purpose of protecting public safety and morals. The kind of cloning regulation considered and enacted thus far, a total prohibition on human cloning, would prohibit married infertile couples from cloning, a use of cloning not likely to threaten traditional family structures or heterosexual relations. Likewise, a total prohibition on human cloning would prevent cloning regardless of whether cloning is actually safer than procreation by other means. Thus, for example, if a woman is a carrier for a genetic disease and her husband is not, cloning the husband's DNA would allow the couple to avoid the risk of passing on the genetic disease to their child. Moreover, if such couple wished to avoid passing the genetic disease to their child by using existing ARTs such as IVF or AID, they would be forced to resort to the use of donor sperm, a choice which involves its own set of risks to the health of the future child. Indeed, a total ban on human cloning would disregard any objective data indicating that

400. See generally, Vernon J. Ehlers, The Case Against Human Cloning, 27 Hofstra L. Rev. 523 (1999); Leon R. Kass, A Debate on Human Cloning: Why We Should Ban the Cloning of Human Beings, 4 TEX. REV. L \& POL. 39 (1999).

401. See supra Part IV.A; infra Parts V.A \& V.B.

402. See, e.g., Williamson v. Lee Optical, 348 U.S. 483, 487 (1955) (upholding, on public health grounds, Oklahoma law prohibiting anyone other than optometrist or ophthamologist from fitting eyeglasses or lenses); McGowan v. Maryland, 366 U.S. 420, 450 (1961) (upholding, on grounds of public morals, Maryland law prohibiting the operation of businesses on Sunday).

403. McLaughlin v. Florida, 379 U.S. 184, 191 (1964).

404. See infra Part V.A.

405. See infra Part V.D.

406. Williamson, 348 U.S. at 489. 
the procedure is safe and would apply without regard to improvements in procedure that provide an acceptable level of risk or a level of risk that is comparable to existing means of procreation. ${ }^{407}$

The Court, however, views over-inclusiveness in much the same way as it views under-inclusiveness; significant over-inclusiveness is also tolerated under rational basis review. ${ }^{408}$ Thus, although a total prohibition on human cloning would likely suffer from significant problems of over- and under-inclusiveness, these defects, standing alone, would not likely warrant invalidation under the Equal Protection Clause. ${ }^{409}$ If the opponents of anti-cloning laws wish to establish an equal protection violation, it would be necessary to convince the court that the proffered justifications for such a ban, protecting public safety and morals, mask a discriminatory animus against a class of individuals, as was the case in Cleburne (mentally disabled) and Romer (homosexuals and bisexuals).

Is there a discriminatory purpose underlying the quest to prohibit human cloning? One possible argument is that opponents of human cloning are motivated by a desire to discriminate against women and homosexuals. After all, one of the aspects most disturbing to opponents of human cloning is that cloning fundamentally alters the traditional procreation equation of "man plus woman equals baby." It is, in fact, the only known method of procreation, short of parthenogenesis, ${ }^{410}$ which does not require sperm for the fertilization of the egg. ${ }^{411}$

Cloning thus essentially renders male involvement unnecessary in the propagation of life. The only items necessary for procreation by cloning is an egg and a womb. This point is raised not to make male readers uncomfortable, but rather to note that a legislative ban on human cloning would disproportionately impact women, particularly lesbians, since cloning would allow women to procreate without male involvement and the risks inherent in using donated sperm. Because cloning is the only known female-exclusive method of procreation, it broadens women's opportunities to have children, opportunities which traditional, sexual forms of procreation such as intercourse, IVF, or artificial insemination do not. Moreover, because procreation using sperm involves a risk not present with cloning, some women rationally may prefer cloning to the more traditional, sexual methods.

407. For a more detailed discussion of the risks inherent in existing means of procreation, see supra notes 148-159 and accompanying text.

408. See, e.g., New York Transit Auth. v. Beazer, 440 U.S. 568 (1979).

409. See Vance v. Bradley, 440 U.S. 93, 108 (1979) ("Even if the classification involved . . . is to some extent both underinclusive and overinclusive, and hence the law drawn ... is imperfect, it is nevertheless the rule that ... perfection is by no means required.").

410. Parthenogenesis, or "virgin birth," is the spontaneous duplication of the DNA inside an egg. See supra note 29.

411. Interestingly, cloning uses a "sperm substitute," specifically, a mild electric current, to stimulate the process of cell division and the formation of the embryo. See Kolata, supra note 30. 
The possible discriminatory impact of a cloning ban on homosexuals and women would not be enough, ipso facto, to warrant invalidation under the Equal Protection Clause; a discriminatory purpose would have to be demonstrated. ${ }^{412}$ Proving such discriminatory animus would be difficult in light of the fact that any anti-cloning legislation is likely to be neutral on its face, prohibiting the practice for all individuals regardless of sexual orientation or gender. ${ }^{413}$ Thus, a ban on human cloning would be distinguishable from, for example, Colorado's Amendment 2, which singled out individuals on the basis of sexual orientation. And while some anti-cloning advocates do appear, albeit often sub rosa, to harbor discriminatory animus against women or homosexuals, ${ }^{414}$ a court reviewing a law banning human cloning would be hard-pressed to imply such animus. If, therefore, a ban on cloning is not viewed as infringing upon a fundamental right, a challenge to such a law based upon the Equal Protection Clause would not likely be successful.

\section{The Governmental InTERest In Regulating HumaN CLONING}

Because various fundamental constitutional rights may arguably be infringed by a ban on human cloning, the salient question is whether the

412. See Romer v. Evans, 517 U.S. 620, 634-35 (1996); Personnel Administrator of Mass. v. Feeney, 442 U.S. 256, 279 (1979).

413. See, e.g., Mich. CoMP. LAWS $\$ 333.16274-75$ (1999).

414. See, e.g., 144 CONG. REC. S603 (daily ed. Feb. 11, 1998) (statement of Sen. Brownback) ("Human cloning distorts the relationship between man and woman by negating the necessity of either one in the creation of new life and consequently also usurps the role of God in the creation of new life."); 143 CONG. REC. H713 (daily ed. Mar. 4, 1997) (statement of Rep. Ehlers) ("The good Lord ordained a time-honored method of creating human life, commensurate with substantial responsibility on the part of the parents, the responsibility to raise a child appropriately."); Daniel R. Heimbach, Cloning Humans: Dangerous, Unjustifiable, and Genuinely Immoral, 32 VAL. U. L. REV. 633, 650-655 (1998) (asserting that only relationships between males and females are moral); Leon R. Kass, The Wisdom of Repugnance: Why We Should Ban the Cloning of Human Beings, 32 VAL. U. L. REV. 679, 682 (1998) ("Thanks to feminism and the gay rights movement, we are increasingly encouraged to treat the natural heterosexual difference and its preeminence as a matter of 'cultural construction.'. . . For this new dispensation, the clone is the ideal emblem: the ultimate 'single-parent child."'); NBAC REPORT, supra note 8, at 51-52; Ian Wilmut, Dolly's False Legacy, TiME, Jan. 11, 1999, at 74:

Each of us can imagine hypothetical families created by the introduction of a cloned child - a copy of one partner in a homosexual relationship or of a single parent, for example. What is missing in all this is consideration of what's in the interests of the cloned child. ... [M]y judgment is that it would be difficult for families created in this way to provide an appropriate environment for the child.

Id. For an excellent discussion of how the availability of cloning would affect homosexuals, see William N. Eskridge, Jr. \& Edward Stein, Queer Clones, in CloneS AND Clones: Facts and Fantasies About Human Cloning 95-113 (Martha C. Nussbaum \& Cass R. Sunstein eds., 1998). 
government has a sufficiently compelling interest in stopping the practice and whether any ban enacted is tailored to further such a compelling interest.

The primary governmental interests proffered, to justify proposed and enacted bans on human cloning include: (1) preserving the traditional family; 15 (2) protecting personal autonomy and privacy; ${ }^{416}$ (3) preserving the sanctity of human life; ${ }^{417}$ (4) protecting the health and safety of human embryos; ${ }^{418}$ and (5) preserving human genetic diversity. ${ }^{419}$

\section{A. Preservation of Marriage and the Family}

Analogous to the objections initially voiced regarding artificial insemination ${ }^{420}$ and IVF, ${ }^{421}$ opponents of human cloning assert that cloning would undermine the importance and necessity of marriage and family. ${ }^{422}$ Opponents of human cloning have even asserted, as they have with other ARTs, that cloning humans would be adulterous. ${ }^{423}$ The basis of these objections appears to be that because cloning allows for reproduction by one person, ${ }^{424}$ it "makes commitment to any sort of on-going family relationship between adults unnecessary. . . [and] requires no fidelity to a spouse because no spouse is anywhere included in the process by which clonal-life is generated." ${ }^{, 425} \mathrm{Or}$, as Leon Kass has expressed it, a clone would be "the ultimate 'single parent' child," representing yet another step down the slippery slope begun by "the prominence and the acceptability of divorce and out-of-wedlock births." 426

At bottom, these "family values" objections to human cloning are, of course, moral objections rooted in specific (often religiously based) views of what constitutes a normatively desirable family. As Laurence Tribe eloquently put it, "Cloning is the technological apotheosis of Murphy Brown and Ellen DeGeneres,

415. See infra Part V.A.

416. See infra Part V.B.

417. See infra Part V.C.

418. See infra Part V.D.

419. See infra Part V.E.

420. See supra notes 331-340 and accompanying text.

421. See supra notes 341-351 and accompanying text.

422. See, e.g., Posner \& Posner, supra note 136, at 238 ("Already we observe many people choosing not to marry. There would be more-and with a tilt not observed today toward the genetically and financially privileged-if human cloning were feasible and cheap. Cloning would thus be 'anti-marriage,' and, even if cheap, would benefit mostly rich men and women."); Heimbach, supra note 414, at 650 (1998) (stating that "human cloning is inherently immoral because it violates the moral institution of parenthood" and because it "both trivializes and violates the covenental nature of marriage as a moral institution").

423. See Heimbach, supra note 414 , at 651 .

424. In the case of a male who wanted to clone himself, an additional person-a surrogate mother-would, of course, be required.

425. Heimbach, supra note 414 , at 651 .

426. Leon Kass, supra note 414 , at $17,18$. 
the biomedical nemesis of Dan Quayle, Phyllis Schlafly, and Pat Robertson."\$27 Indeed, the family values argument presupposes that the only normatively desirable "family" consists of a married woman and man and their biologically related children. Even within this rather narrow vision of what constitutes a family, there is a distinct additional preference for the married woman and man to conceive their children via sexual intercourse rather than the use of ARTs.

To many individuals, cloning represents a threat to this traditional vision of family. Cloning would further "de-link" sex and procreation, providing another manner of creating children without the necessity of sexual intercourse. This effect, however, is not unique to cloning. ARTs are, by their very nature, designed to provide a means by which children may be conceived without the necessity of coitus, which is either impossible or ineffective for infertile couples. Likewise, adoption allows individuals to have children without sex, while others have sex without the responsibility of raising the resulting children. Yet, ironically, many of the same people who criticize cloning for devaluing sex are ardent supporters of adoption. ${ }^{428}$ Thus, if one accepts the family values argument as sufficient for justifying a ban on human cloning, the ineluctable conclusion is that a similar ban on the use of adoption or ARTs, such as IVF or artificial insemination, likewise would be legally justifiable.

Family values adherents appear to have much deeper objections to human cloning than they do to adoption or existing ARTs. This may be due to the fact that human cloning poses a threat that existing ARTs do not: namely, expanding the opportunities of women and homosexual couples to conceive biologically related children. Currently, women and homosexual couples desirous of having a biologically related child must either find a surrogate willing to gestate the child (in the case of homosexual men) or find a willing sperm donor (in the case of women). Cloning would permit women and homosexuals to have a child that is biologically related, without the need for donated gametes and all the attending risks and psychological harms.

Providing such reproductive freedom to women and homosexuals is unsettling to many with traditional concepts of what constitutes a "family." Many individuals who feel unsettled by this scenario necessarily believe that it is normatively undesirable for homosexual qua homosexuals to have children, ${ }^{429}$

427. Laurence Tribe, On Not Banning Cloning for the Wrong Reasons, in CLONES and Clones: Facts and Fantasies About Human Cloning 221, 227 (Martha C. Nussbaum \& Cass R. Sunstein eds., 1998).

428. See, e.g., Michigan Right-to-Life web site (visited Sept. 23, 2000) <http://www.rtl.org/html/summer1998.html> (expressing support for Michigan cloning ban); Michigan Right-to-Life web site (visited Sept. 23, 2000) <http://www.rtl.org/html/adoption_focus.html> (expressing support for adoption as an alternative to abortion).

429. See, e.g., Wilmut, supra note 414 , at 74 :

Each of us can imagine hypothetical families created by the introduction of a cloned child-a copy of one partner in a homosexual relationship or of a single parent, for example. What is missing in all this is consideration of what's in the interests of the cloned child. . . [M]y 
although many (if not most) such couples desirous of having children would likely be in long-term, committed relationships generally deemed conducive to the rearing of healthy, well-adjusted children. Perhaps part of the fear may also be that children of homosexuals will grow up to be homosexuals as well, although this fear appears to be empirically unfounded. ${ }^{430}$ Proposals to restrict human cloning to married couples may therefore be based on such discrimination and fears, since generally only heterosexuals are permitted to marry. ${ }^{431}$

Another aspect of human cloning that is antithetical to those with traditional notions of family is that it would permit women, whether homosexual or heterosexual, to procreate without men. The fear, therefore, is that men will no longer be "necessary" to women, and hence, if cloning were available, many women will opt not to marry or enter into heterosexual relationships. ${ }^{432}$ As an initial matter, one must seriously question whether such fears have any rational foundation, given the strong cultural, emotional, financial, and physical interests most women have in marrying and having sexual relationships (and children) with men. Moreover, given the tremendous number of births each year to single mothers, ${ }^{433}$ it seems unlikely that the availability of cloning, likely an expensive and time-consuming procedure, ${ }^{434}$. would be so much more attractive than intercourse or other existing ARTs that the numbers of single mothers would increase significantly.

Additionally, even assuming arguendo that cloning would, in fact, result in an increase in the number of children born to single women and homosexual couples, does this necessarily weaken the concept of family or the institution of

Id.

judgment is that it would be difficult for families created in this way to provide an appropriate environment for the child.

430. PENCE, supra note 33, at 114 (noting that a 1992 study by University of Virginia psychologist Charlotte Patterson found that almost all children raised in homosexual households were heterosexual).

431. Indeed, because homosexuals are not generally permitted to marry, individuals who argue that the fundamental right of procreation should be limited to married individuals would deny homosexuals the right to have biologically related offspring. If the fundamental right of procreation extended to homosexuals, an odd situation would develop: homosexuals would not have a constitutional right to engage in homosexual activity, Bowers v. Hardwick, 478 U.S. 186, but they would have the right to conceive and raise biologically related children. Although admittedly strange, such a situation would perhaps be explained by the Bowers Court's statement that "[n]o connection between [the] family, marriage, or procreation on the one hand and homosexual activity on the other has been demonstrated." Id. at 191.

432. See, e.g., Susan Cohen, A House Divided, WaSH. POST MAG., Oct. 12, 1997, at W12.

433. In the early 90 s, approximately $41 \%$ of babies were born to unwed mothers. Donald Bradley, New Attitudes Surround New Mothers: Birth Rate Soars for Women Who Are Not Married, KANSAS CITY STAR, Nov. 10, 1999, at A9.

434. Indeed, the cost for undergoing existing ART procedures is astronomical, with costs for IVF averaging around $\$ 10,000-15,000$. See Darryl E. Owens, In Vitro Parenthood, CHI. TRIB., Dec. 1, 1999, at C7; Barbara Vobejda, Egg Donation: A Growing Business, WASH. POST, Mar. 7, 1999, at Al. 
marriage? To some individuals, the answer is clearly "yes." But to others, expanding the concept of what constitutes a family, or, for that matter, a marriage, does not, ipso facto, weaken those concepts. If one defines these terms not with reference to who may properly belong to such institutions, but rather with reference to what such institutions stand for, there is room for expansion without undermining the basic function and purpose of the institutions. If, therefore, the institution of the family refers to one or more individuals who are committed to ensuring each other's welfare due to a biological or deep emotional relationship, ${ }^{435}$ then cloning could expand, not undermine, this institution. Likewise, cloning, by potentially providing an undiluted genetic link between parent and child, could strengthen some marriages by increasing the possibility of conceiving biologically related children and by making it psychologically harder to walk away from a marriage that had produced a child who looked just like his or her parent. ${ }^{436}$

Whether or not one accepts these asserted societal ills associated with human cloning, the salient question is whether preventing such societal ills is a sufficiently substantial or compelling governmental interest to warrant interference with an individual's constitutional rights. Preservation or protection of the institution of marriage or the family may well serve a compelling governmental interest, ${ }^{437}$ as evidenced by laws imposing fines and/or criminal sanctions upon those who commit adultery, ${ }^{438}$ fornication, ${ }^{439}$ or incest. ${ }^{440}$

435. Indeed, in Moore v. City of East Cleveland, 431 U.S. 494 (1977), the Court invalidated a housing ordinance that limited the occupancy to single families, defining "family" in such a way as to prohibit a grandmother from occupying a household with her two grandsons, who were first cousins rather than brothers. The Court reasoned:

Our decisions establish that the Constitution protects the sanctity of the family precisely because the institution of the family is deeply rooted in this Nation's history and tradition. . . . Ours is by no means a tradition limited to respect for the bonds uniting the members of the nuclear family. The tradition of uncles, aunts, cousins, and especially grandparents sharing a household along with parents and children has roots equally venerable and equally deserving of constitutional recognition.

Moore, 431 U.S. at 503-04. Indeed, the dictionary definition of "family" appears to echo this conceptualization, defining family as, inter alia, "a group of persons of common ancestry"; or "a group of individuals living under one roof and usu. under one head"; or "the basic unit in society having as its nucleus two or more adults living together and cooperating in the care and rearing of their own or adopted children."

436. PENCE, supra note 33, at 112.

437. See Oliverson v. West Valley City, 875 F. Supp. 1465, 1485 (D. Utah 1995) ("The State of Utah and the defendants have a compelling state interest in preventing adultery."); In the Interest of Tiffany Nicole M., 571 N.W.2d 872, 876-80 (Wis. Ct. App. 1997) (applying strict scrutiny and upholding incest statute in face of due process and equal protection challenges). But see Doe v. Duling, 603 F. Supp. 960 (E.D. Va. 1985) (invalidating Virginia formication statute on grounds that it violates the constitutional right of privacy).

438. See, e.g., Ala. CODE § 13-A-13-2 (1994 \& Supp. 1999); ARIZ. Rev. STAT. ANN. § 13-1408 (1999); Colo. REv. STAT. § 18-6-501 (1999); MICH. COMP. LAWS § 750.29 (1999). 
But even if a ban on human cloning is designed to further the purpose of alleviating certain societal ills, the courts will look to see whether there are other activities that may contribute to the identified societal ills but which have not been legally prohibited. ${ }^{441}$ Failure to restrict such other activities thus becomes relevant to whether the law in question is "necessary" to further the asserted governmental interest. ${ }^{442}$ In the context of human cloning, the failure of the government to restrict other activities that cause the identified societal ills, undermining marriage and the traditional family structure, may therefore be relevant to whether a ban on human cloning is necessary to further this asserted interest. If, in other words, there are other, highly analogous activities that undermine the asserted interests (marriage and family) in the same manner, then the government's failure to restrict such analogous activities tends to undermine this asserted justification for restricting human cloning. ${ }^{443}$

Indeed, there are analogous activities that likely contribute to the same sorts of societal ills as human cloning that are not restricted by the government. Other ARTs are widely believed to contribute to the same social ills as human cloning $^{44}$ but are not prohibited or otherwise legally restricted. The failure to prohibit or restrict the use of ARTs such as IVF or artificial insemination suggests that restricting human cloning is not necessary to further the asserted interests of preserving marriage and the traditional family structure.

Moreover, even assuming a total prohibition against human cloning would serve substantial or compelling governmental interests (e.g., preservation of the family and marriage), such a law would not be narrowly tailored to further such interests. ${ }^{445}$ There are more narrowly tailored means, short of a total prohibition, that would be available to advance these interests. One option would

439. See, e.g., GA. CODE ANN. § 16-6-18 (1998); IDAHo CODE § 18-6603 (1997); MASS. GEN. L. ch. 272, § 18 (1998); MISS. CODE ANN. § 97-29-3 (1972); N.C. GEN. STAT. ANN. § 14-184 (1999).

440. See, e.g., ALA. CODE § 13A-13-3 (1994 \& Supp. 1999); ARIz. REv. STAT. ANN. § 13-3608 (1999); CAL. PENAL CODE § 285 (1999); MASS. ANN. LAwS ch. 272, § 17 (2000); MICH. StAT. ANN. $§ 28.788(2)$ (Callaghan 1999); N.Y. PENAL LAW § 255.25 (Consol. 2000).

441. See Greater New Orleans Broad. Ass'n. v. United States, 527 U.S. 173, 18593 (1999) (commenting, in context of law prohibiting private casino gambling advertising, . on congressional allowance of casino gambling advertising by other types of gambling facilities).

442. See id. at 191-93 ("While Congress' failure to institute such direct regulation of private casino gambling does not necessarily compromise the constitutionality of [the law in question], it does undermine the asserted justifications for the restriction before us.") (emphasis added).

443. See id.

444. See supra notes 331-349 and accompanying text.

445. Cf. Griswold v. Connecticut, 381 U.S. 479, 498 (1965) (Goldberg, J., concurring) ("But, in any event, it is clear that the state interest in safeguarding marital fidelity can be served by a more discriminately tailored statute, which does not, like the present one, sweep unnecessarily broadly, reaching far beyond the evil sought to be dealt with ...."). 
be to restrict the use of human cloning to married couples. Another option would be to limit cloning to married couples who are unable to conceive by other methods of procreation. Thus, if one accepts that human cloning could undermine the institutions of marriage or the traditional family structure, these more narrowly tailored legislative alternatives would minimize these perceived risks without infringing unnecessarily upon constitutional freedoms. As Justice Goldberg so eloquently stated in his concurrence in Griswold v. Connecticut, "[P]recision of regulation must be the touchstone in an area so closely touching our most precious freedoms." $\$ 446$

\section{B. Protecting Personal Autonomy and Privacy}

Another objection voiced by opponents of human cloning is that a child born by cloning inherently would be deprived of the kind of personal autonomy and privacy enjoyed by other persons. ${ }^{447}$ Philosopher Hans Jonas labeled this argument the "right to ignorance," ${ }^{\text {, } 448}$ and philosopher Joel Feinberg labeled it a "right to an open future." same: the genome of the child created by cloning, being a known quantity, is ineluctably denied a full opportunity for individuality because he is burdened with the foreknowledge of himself. ${ }^{450}$ As George Annas puts it, "[A]ll human children should have the right to live an uncharted life, a life filled with choices they must make themselves, not choices forced on them by another's fixation on duplicating or copying parts of an already lived life."45! If therefore, a child is merely a "later born twin" of her DNA donor, her fate may already be predetermined, resulting in severe psychological pressure and a loss of individuality. ${ }^{452} \mathrm{~A}$ correlative concern is that because a person created by cloning is a near-exact genetic match of his DNA donor, he will lack the same degree of privacy as individuals who possess a unique genotype. ${ }^{453}$ Thus, if the adult DNA donor had a receding hairline at age thirty-five, was only five feet tall, or had a genetic predisposition to develop

446. Id. at 498 (Goldberg, J., concurring).

447. See, e.g., NBAC REPORT, supra note 8, at 67 ("With the prospect of somatic cell nuclear transfer cloning comes a scientifically inaccurate but nonetheless instinctive fear of multitudes of identical bodies, each housing personalities that are somehow less than distinct, less unique, and less autonomous than usual."); see also Dan W. Brock, Cloning Human Beings: An Assessment of the Ethical Issues Pro and Con, in ClONES AND CLONES: FACTS AND FANTASIES ABOUT HUMAN Cloning 141, 155 (Martha C. Nussbaum \& Cass R. Sunstein eds., 1998).

448. NBAC REPORT, supra note 8, at 67.

449. Id.

450. See PENCE, supra note 32, at 138.

451. Annas, supra note 21, at 275.

452. See, e.g., Kass, supra note 414, at 698 ("The child is given a genotype that has already lived, with full expectation that this blueprint of a past life ought to be controlling of the life that is to come.").

453. He could also be the victim of genetic discrimination in the workplace or in the issuance of insurance policies. See RIFKIN, supra note 45, at 160-69 (documenting the current extent and forms of genetic discrimination). 
prostate cancer, the world would know that the clonal child would also later develop or share these traits.

While these arguments, if true, are disconcerting, there is simply no way of determining if such a loss of individuality would, in fact, occur. ${ }^{454}$ Indeed, one must stop to wonder: how would anyone ever know that a child was conceived by cloning techniques unless the parents revealed this information? After all, it is not as though children created by cloning will have distinctive markings or characteristics that will set them apart from the rest of humankind. Thus, unless the parents announced that their child was created by cloning, neither the child nor anyone else would have any reason to treat the child as anything less than an individual. While the child created by cloning would have a remarkable resemblance to the DNA donor, the DNA donor may or may not be that child's rearing parent. Even assuming arguendo that the DNA donor is also the child's rearing parent, it is not unusual for a child to have an eerie resemblance to a parent. Such resemblance does not, however, cause us to treat such a child as anything less than an individual.

Moreover, although there is disagreement as to the precise degree that environmental factors (nurture) as opposed to genetic factors (nature) plays in individual development, they undoubtedly play an important role. ${ }^{455} \mathrm{~A}$ lifetime of exposure to environmental factors different from those experienced by the DNA donor can result in a very different life experience for the individual created by cloning. ${ }^{456}$ Something as simple as the foods a woman eats (or does not eat) during pregnancy, for example, can have a profound effect on the health and development of a fetus. ${ }^{457}$ Likewise, the gestational mother's exposure to teratogenic substances such as alcohol or tobacco may dramatically affect fetal health. ${ }^{458}$ It is even speculated that the intrauterine environment may have a strong effect on overall intelligence. ${ }^{459}$

Environmental influences extend, of course, beyond the womb, and therefore could be expected to continue affecting the development and health of

454. See NBAC REPORT, supra note 8, at 66 ("[A]ll of these concerns [about a loss of individuality] are not only quite speculative, but are directly related to certain specific cultural values."); PENCE, supra note 33, at 138 ("To assume that such a child's future is not open is incorrectly to assume naive genetic reductionism.").

455. See SILVER, supra note 42, at 213.

456. This is the lesson of Ira Levin's book, The Boys from Brazil. In this tale, a surviving Nazi leader who had fled to South America nefariously creates 94 clones of Adolf Hitler. The reader, however, learns that these young clonal Hitlers are very different from the original because they have grown up in very different environments and thus pose no threat to mankind. Thus, the Nazi hunters ultimately become convinced that it is not necessary to kill the young Hitlers. See generally IRA LEVIN, THE BOYS FROM BRAzIL (1976).

457. It is widely accepted, for example, that the proper consumption of folic acid while pregnant can significantly help avoid neural-tube defects. See 21 C.F.R. $\S 101.79$ (2000).

458. See laura E. Berk, Child Development 92-102 (4th ed. 1997).

459. See B. Devlin et al., The Heritiability of IQ, 388 NATURE 468, 469 (1997). 
the individual created by cloning, creating significant differences from his DNA donor. The individual may, for example, become an alcoholic or drug addict. ${ }^{460} \mathrm{He}$ may be exposed to carcinogenic substances in his water, the air he breathes, or at his place of work. Moreover, an individual created by cloning could simply rebel against his or her genetic heritage, refusing to take piano lessons despite the fact that Daddy (the DNA donor) is an accomplished concert pianist. ${ }^{461}$ As the NBAC Report concluded:

[T] a team of Michael Jordans, a physics department of Albert Einsteins, or an opera chorus of Pavorottis, is simply false. Knowing the complete genetic makeup of an individual would not tell you what kind of person that individual would become. . . The increasingly sophisticated studies coming out of human genetics research are showing that the better we understand gene function, the less likely it is we will ever be able to produce at will a person with any given complex trait. ${ }^{462}$

The important role that differences in environment play in individual development is exemplified in the case of identical twins. Who among us has not known identical twins who were as different as night and day? Perhaps because identical twins look so much alike, they strive to assert their individuality in the way they dress, comb their hair, the sports they play, and the friends with whom they associate. As one researcher has concluded, "Identical twins are clearly less behaviorally alike than most people think. Identical twin correlations for physical characteristics, intellectual abilities, personality traits, vocational interests, and social attitudes are all less than 1.0, meaning that prenatal, perinatal, and postnatal environments affect virtually every measured human trait." ${ }^{9463}$ If such drastic differences are possible with identical twins who are raised in the same home environment, ${ }^{464}$ it seems logical to assume that a later-born twin who, by

460. Although many believe that alcoholism or drug dependency may be caused by genetic factors, there is no definitive conclusion on this theory. See Norbert Gilmore, Drug Use and Human Rights: Privacy, Vulnerability, Disability and Human Rights Infringements, 12 J. CONTEMP. HEALTH L. \& Pol'y 355, 386-89 (1996). Moreover, even those who believe there may be a genetic predisposition toward substance abuse seem to admit that many other environmental factors play an important role in the ultimate manifestation of abuse. See id. at 367 n.33.

461. See SiLVER, supra note 42, at 213 ("[1]nnate talent in music, math, or athletics will not be enough to turn a child into a skilled musician, mathematician, or athlete, if she chooses to ignore the starting points provided within her genes.").

462. NBAC REPORT, supra note 8, at 32.

463. Nancy L. Segal, Behavioral Aspects of Intergenerational Human Cloning: What Twins Tell Us, 38 JURIMETRICS 57, 63 (1997).

464. See NBAC REPORT, supra note 8, at 32 ("Even identical twins who grow up together and thus share the same genes and a similar home environment have different likes and dislikes, and can have very different talents."). 
definition, would grow up in a very different environment from his DNA donor ${ }^{465}$ could similarly assert a great deal of individuality.

To the extent, therefore, that opponents of human cloning are concerned about the ability of children conceived by cloning to assert individuality, the problem may lie more with the fears and disapproval of cloning opponents than with any inherent problem with possessing the same genotype. Laurence Tribe, who originally expressed some reservations about human cloning, ${ }^{466}$ has recently revealed that he is now more concerned with the effects a cloning ban would have on psyches of clonal children and society as a whole. ${ }^{467}$ His thesis is that children created by cloning will be socially stigmatized. ${ }^{468}$ While such stigmatization may initially manifest itself in feeling sorry for such children, such children are "likely in the end to become the object of a form of contempt: the contempt that the (supposedly) spontaneous, natural, and unplanned would tend to feel toward the (supposedly) manufactured and allegedly artificial." ${ }^{\text {"469 }}$ Gregory Pence likewise asks us to "notice that almost all the expected harm to the child stems from the predicted, prejudicial attitudes of other people to the [clonal] child. ('Would you want to be a cloned child? Can you imagine being called a freak and having only one genetic parent?')."470 The concern for the psychological well-being of individuals created by cloning thus takes on the tone of a self-fulfilling prophecy, analogous to the concerns widely held for many years for illegitimate children. As the Supreme Court observed in Weber v. Aetna Casualty \& Surety Co., ${ }^{471}$ "The status of illegitimacy has expressed through the ages society's condemnation of irresponsible liaisons beyond the bonds of marriage. But visiting this condemnation on the head of an infant is illogical and unjust. . . "472 Given the

465. The differences presumably would be even greater if the child created by cloning was born after the death of the DNA donor (i.e., posthumously). This is so because not only would the individual grow up in a different environment from the DNA donor, but also because the donor would not be alive to constantly remind the clonal individual of his genetic heritage.

466. See Laurence H. Tribe, Technology Assessment and the Fourth Discontinuity: The Limits of Instrumental Rationality, 46 S. CAL. L. REV. 617 (1973).

467. Wrong Reasons, supra note 67, at 221:

Should human cloning be forbidden altogether? Although I offer no definitive answer to that inquiry, I explore what I have come to regard as a particularly forceful objection to any regime of prohibition in this technological realm -an objection centered on how the very fact of prohibition, and the social meanings likely to attend it, might be expected to reshape in strikingly negative ways, the structure of social relations and the status of the human lives that those social relations in turn affect.

Id.

468. See generally Wrong Reasons, supra note 67, at 221-32.

469. Id. at 230; see also id. at 229 ("[E]ven if the judgment begins with sympathy, its very structure entails an enormous risk that it will end in condemnation, in some version of original sin.").

470. PENCE, supra note 33, at 138.

471. 406 U.S. 164 (1972).

472. Id. at 175 . 
highly speculative nature of this concern, it likely would not rise to the level of a compelling interest. ${ }^{473}$

Even assuming arguendo that some individuals created by cloning would suffer psychological harm, such as a loss of individuality or identity, a law that banned all human cloning would nonetheless fail strict scrutiny because it would not be narrowly tailored to further the government's interest in preventing such harm. Indeed, a law that banned all human cloning would effectively presume that non-existence for all individuals created by cloning would be preferable to existence. Such a legislative presumption obviously sweeps too broadly, since many individuals would likely suffer no psychological harm at all and may gain psychological benefits, while others who do suffer some psychological harm may conclude that living a life with such psychological baggage is preferable to not living at all. If, therefore, the governmental interest in regulating human cloning is to prevent psychological harm to the potential children of cloning, it would appear that a more narrowly tailored law, such as a law providing for governmentally sponsored counseling to such individuals, would be both achievable and constitutionally preferable. Likewise, if the governmental interest in regulating human cloning is to prevent a loss of individual privacy, it would undoubtedly be preferable, from a constitutional perspective, to allow such individuals to be born and to enact narrowly tailored laws designed to protect such individuals' privacy - such as a law restricting or prohibiting the dissemination of information relating to the manner of one's conception, without the consent of the affected individual.

\section{C. "Playing God": Preserving the Sanctity of Human Life}

Perhaps one of the most powerful emotional arguments against human cloning is that it represents a foolish attempt by humankind to "play God." argument presumes pre-defined realms within which humankind may properly operate, with any attempt to exceed such realms resulting in disaster. This argument clearly has deep theological roots. Genesis tells the familiar story of the Garden of Eden, in which Adam and Eve are told by God not to eat from the Tree of Knowledge. ${ }^{475}$ With prodding from the serpent (representing evil), Eve disregards God's warning and partakes of the forbidden fruit. ${ }^{476}$ Henceforth, humankind is cast into a state of knowledge, aware of its nakedness, and stripped of the bliss of ignorance. ${ }^{47}$

The story of the Garden of Eden is often cited as a Biblical warning of the harms that can be caused from attempting to satiate the human appetite for

473. See Stanley v. Georgia, 394 U.S. 557, 566-67 (1969) (concluding that "[g]iven the present state of knowledge" there "appear[ed] to be little empirical evidence" to support Georgia's assertion that prohibiting the possession of obscene materials would prevent deviant sexual behavior and crimes of sexual violence).

474. See NBAC REPORT, supra note 8, at 44-45.

475. Genesis 2:17 (King James).

476. See id. at 3:6.

477. See id. at 3:7. 
curiosity with the "forbidden fruit" of knowledge. Of course, the story of the Garden of Eden can be interpreted as a tale of the benefits that can accrue to humankind by consuming such forbidden fruit. True, consumption of the fruit cast Adam and Eve (and all of humankind) out of the Garden of Eden, with its peaceful state of blissful ignorance. ${ }^{478}$ But exile from the Garden also brought selfawareness, allowing humankind to shed the veil of ignorance and obtain a deeper understanding of its place in God's scheme. ${ }^{479}$ Indeed, perhaps the moral of the story of Garden and Eden is that it is humankind's unique "burden" to have selfconscious knowledge. Viewed in this light, knowledge, even knowledge that brings awareness of one's own limitations and insignificance, is a net good.

Of course, not all people can accept such an interpretation of the story of the Garden of Eden. But this is precisely the point. The "playing God" objection to human cloning is undeniably theologically and hence morally based. ${ }^{480}$ It attempts to impose upon society a specific interpretation of Biblical scripture with which others may not agree. Thus, one of the chief problems, from a pragmatic perspective, with the playing-God objection is that the basic fears it attempts to allay are not capable of rational delineation. Precisely what constitutes playing God is, in other words, impossible to define, unless one knows for sure where humans end and God begins.

One can always look to religious texts, such as the Bible, for guidance on such line-drawing. But where one draws the line is a question upon which reasonable minds have differed for centuries. Is, for example, the use of condoms playing God by interfering with the natural function of intercourse? Or perhaps wearing prescription eyeglasses is playing God, because God intended a nearsighted person's eyes to deteriorate? Is the use of fertilizers playing God by disturbing the natural composition of soil? Indeed, if one takes the playing-God objection to its rational extreme, virtually all man-made products and services play God by interfering with the natural order. ${ }^{481}$

Perhaps the most blatantly intrusive area (in a theological sense) is modern medicine, because medicine, more than any other human endeavor, directly affects human mortality. One need only recall the adamant objections to

478. See id. at 3:6-3:7.

479. See id. at 3:7.

480. See, e.g., Heimbach, supra note 414, at 656:

To those who follow the moral tradition of the Hebrew Scriptures and who find in them the moral authority of God, cloning human life must be immoral not only because it involves immoral processes ... but also because it is driven by and in turn provokes three kinds of immoral desires, the desire to reach immortality on our own terms without God, the desire to preempt God by assuming his place, and the desire to Id. worship human beings (either self or another) in the place of God.

481. As Lee Silver cogently observed, "The smallpox virus was part of the natural order until it was forced into extinction by human intervention. I doubt that anyone mourns its demise." SILVER, supra note 42, at 219. 
organ transplantation to confirm this proposition. ${ }^{482}$ Indeed, all of modern medicine essentially plays God in this sense, from antibiotics to antidepressants, from ventilators to artificial heart valves. Yet there are no widespread theological objections to these medical advancements.

Such moral objections, however heartfelt, cannot serve as a valid basis for banning human cloning. In Casey, the Supreme Court acknowledged the widespread moral objections to abortion, but concluded that such moral objections "cannot control our decision. Our obligation is to define the liberty of all, not to mandate our own moral code." $" 483$ Such moral, theologically based objections not only fail to provide a sufficiently compelling or significant governmental interest, but they may also run afoul of the Establishment Clause of the First Amendment. ${ }^{484}$

\section{Protecting the Health and Safety of Human Embryos}

Courts have long held that protecting the health and safety of individuals is a sufficiently "compelling interest" to warrant intrusion into fundamental rights. ${ }^{485}$ Thus, laws narrowly tailored to ensure the health and safety of children created by cloning or the person carrying the child to term would be upheld. ${ }^{486}$ The issues are whether: (1) human cloning poses a threat to the health and safety of embryos or children created by cloning; and (2) if so, whether a complete ban on human cloning is necessary to further the governmental interest in protecting such embryos or children.

The NBAC concluded, "At this time, the significant risks to the fetus and physical well being of a child created by somatic cell nuclear transplantation cloning outweigh arguably beneficial uses of the technique." ${ }^{37}$ The psychological harm that could flow to an individual created by cloning has already been discussed in the section addressing objections based upon personal autonomy and privacy. ${ }^{488}$ But what of the potential physical risks to children created by cloning?

482. See BRODY, supra note 344, at 99-104 (documenting general concerns with organ transplantation); id. at 99 (concluding that [n]o public or professional consensus has been reached on the acceptability of brain death as a criterion for the removal of organs for transplant, or on the idea of transplantation itself).

483. Planned Parenthood of Southeastern Pa. v. Casey, 505 U.S. 833, 850 (1992).

484. "Congress shall make no law respecting an establishment of religion ...." U.S. CONST. amend I. If the governmental justification for banning human cloning is that it is antithetical to a certain theology, such a ban would clearly attempt to "establish" a religion by imposing upon society the religious views of the majority.

485. See, e.g., City of Akron v. Akron Ctr. for Reprod. Health, 462 U.S. 416 , 427-29 (1983); Thornburgh v. American College of Obstetricians \& Gynecologists, 476 U.S. 747, 788-89 (1986) (White, J., dissenting).

486. See, e.g., Casey, 505 U.S. at 878 ("As with any medical procedure, the State may enact regulations to further the health or safety of a woman seeking an abortion.").

487. NBAC REPORT, supra note 8, at 63.

488. See infra Part IV.B. 
There are two primary physical risks identified by opponents of human cloning: (1) premature aging ${ }^{489}$ and (2) physical deformity and other abnormalities. ${ }^{490}$ With regard to premature aging, the concern is that a child created by cloning would inherit the cellular age of the DNA donor. ${ }^{491}$ Thus, for example, a child created by cloning the genetic material of a fifty-year-old DNA donor might inherit a fifty-year-old cellular structure, thereby potentially reducing the child's expected life span.

Evidence does exist that indicates that the telomeres, which are the ends of our chromosomes, shorten in mammals as they age due to the constant division of cells. ${ }^{492}$ If the length of the DNA donor's telomeres is then transferred to a child via cloning, the child's life span may be shortened accordingly. ${ }^{493}$ But will such a transfer of shortened telomeres occur with human cloning and, if so, will it likely result in a shorted life span?

As an initial matter, the evidence suggests that the length of telomeres, which vary from species to species, does not correlate to the life span of the various species. ${ }^{494}$ So telomeres may have nothing at all to do with aging. Moreover, the premature aging thesis appears to disregard data indicating that ova contain enzymes known to lengthen telomeres. ${ }^{495}$ Thus, even if an aged DNA donor cloned himself, it is possible that, once placed inside the enucleated egg, the egg would lengthen the DNA donors telomeres to an acceptable size. ${ }^{496}$

Another difficulty with the premature aging thesis is that over ninety percent of an individual's cell division occurs prior to birth; thus, any telomere shortening that occurs after birth may be relatively insignificant. ${ }^{497}$ Indeed, some speculate that if Dolly the sheep had inherited the "old" telomeres of her DNA donor, her "old" telomeres would not have been able to survive the incredible cell division that occurred during her gestation, and she would never have been born, or at least, would have died soon after birth. ${ }^{498}$ Indeed, perhaps the chief difficulty in assessing the premature aging hypothesis is that it is only a hypothesis, and as Gina Kolata rightly points out, "we will just have to wait and find out" if Dolly dies prematurely or not. ${ }^{499}$

489. See NBAC REPORT, supra note 8, at 24; see also Heimbach, supra note 414, at $635-36$.

490. Gregory Pence asserts that there are two primary sources for the creation of physical abnormalities in the context of human cloning: (1) the modification of the donor DNA by methylation; and (2) the re-modeling of the chromosomes. See PENCE, supra note 33 , at 131 . Pence concedes that "[i]t is also theoretically possible, although unlikely, that something totally unknown could go wrong." Id.

491. See NBAC REPORT, supra note 8, at 24; KolATA, supra note 146, at 239-41.

492. See NBAC REPORT, supra note 8, at 23.

493. See id.

494. See id.

495. KOLATA, supra note 146 , at 240.

496. See NBAC REPORT, supra note 8, at 24.

497. KOLATA, supra note 146, at 240.

498. See id.

499. Id. at 241. 
But even assuming, for the sake of argument, that telomere shortening is passed along from the DNA donor to the cloned child, is this a sufficiently compelling reason to justify a total ban on human cloning? A legislative ban would presuppose that nonexistence is preferable to a shortened life. Is preventing premature death a compelling governmental interest if the alternative is no life at all? Perhaps the answer depends on exactly how premature the death is. If one assumes that, at a certain point, say, a death that is premature by twenty years, preventing premature death is a compelling governmental interest, there would certainly be more narrowly tailored means available to effectuate this goal short of a total prohibition on human cloning. For example, a law could be enacted which would restrict the use of human cloning to individuals under a certain age, so that any adverse effects from the transmission of shortened telomeres would be minimized, thereby limiting the degree of premature aging.

The other major concern regarding the physical risk of cloning humans is that genetic manipulation of early-stage embryos would result in genetic and hence physical abnormalities in the children ultimately born. ${ }^{500}$ The NBAC concluded, "If attempted in humans, [somatic cell nuclear transfer cloning] would pose the risk of hormonal manipulation in the egg donor; multiple miscarriages in the birth mother; and possibly severe developmental abnormalities in any resulting child." 501

The risk of hormonal manipulation in the egg donor and multiple miscarriages in the birth mother are, from the perspective of a constitutional assessment, irrelevant. These risks to the donor and the birth mother, while possible, would not constitute a compelling governmental interest sufficient to justify a cloning ban because the consent of these individuals would be required in order to manipulate eggs or gestate the child. The law allows competent adults to consent to undergo medical procedures, no matter how risky, provided they are fully informed of the risks inherent in such procedures. The only remaining relevant consideration, in a constitutional sense, is whether human cloning would pose a risk of abnormalities in the unborn child sufficient to warrant governmental regulation.

As a preliminary matter, it is important to realize that the risk of physical abnormalities is not unique to cloning. A certain percentage of children conceived by sexual intercourse are born with deformities. ${ }^{502}$ Indeed, an estimated forty percent of human embryos created by sexual reproduction do not successfully implant into the womb, and half of these-twenty percent of all human pregnancies-do not successfully implant because of a genetic defect. ${ }^{503}$

500. See NBAC REPORT, supra note 8 , at 63 ("[T]here is virtually universal concem regarding the current safety of attempting to use [somatic cell nuclear transfer cloning] in human beings."); Heimbach, supra note 414, at 635-36.

501. NBAC REPORT, supra note 8, at 63.

502. The incidence of serious deformities in children conceived sexually is one to two percent. PENCE, supra note 33, at 133.

503. Id. at 132 (citing A. Wilcox, et al., Incidence of Early Loss of Pregnancy, 319 NEW ENG. J. MED. 189-94 (1988)). 
Moreover, couples who are recessive carriers of genetic disease may procreate sexually without legal restriction, despite the fact that their child will have a significant chance of having the disease. Despite the dangers inherent in sexual reproduction, no one seriously advocates banning procreation by sexual intercourse. Thus, the salient question is not whether procreation by cloning results in a certain percentage of children born with physical deformities (because all forms of procreation will) but whether the percentage of deformities is so much higher with cloning that regulation is warranted.

Similar concerns about physical abnormalities were voiced by early opponents of IVF, ${ }^{504}$ yet there have been no legislative bans enacted against IVF. There are, in fact, numerous in vitro embryos created by IVF that are deemed defective so as to warrant being discarded rather than implanted. ${ }^{505}$ But the incidence of such defects does not, in fact, appear to be any higher in embryos conceived in vitro than those conceived in vivo (such as through sexual intercourse or artificial insemination). ${ }^{506}$ Moreover, assuming such defects will exist, many likely can be identified in vitro by examination under a microscope. ${ }^{507}$ Thus, the

504. See MCCORMICK, supra note 336, at 323 ("There is at present no way of finding out whether the viable progeny of [IVF] will be deprived or retarded. Nor would a willingness to practice abortion on the deformed solve the problem, since many such deformities cannot and will not be identifiable by amniocentesis."); FROMER, supra note 27, at 271 (discussing the risk of birth defects that may be caused from attempted implantation of the fertilized ovum into the uterus).

505. See Douglas J. Cusine, Experimentation: Some Legal Aspects, in EXPERIMENTS ON EMBRYOS 120, 123 (Anthony Dyson \& John Harris eds., 1990):

The problem is that, if one is going to permit in vitro fertilization then one must accept a possibility that the embryo or some of the embryos which are produced are going to be defective. After they are examined under the microscope it may be judged dangerous to reimplant a certain embryo either because it would not implant, or because it would create a Id. spontaneous abortion, or because a defective child might result.

506. See Robert Edwards, Ethics and Embryology: The Case for Experimentation, in EXPERIMENTS ON EMBRYOS 42, 45 (Anthony Dyson \& John Harris eds., 1990):

These [arguments regarding the risk of abnormalities in embryos created by IVF] did not impress us [scientists working in the field] because numerous studies on animals had shown that the preimplantation embryo is highly resistant to teratogenic change, i.e., a change which tends to produce abnormalities of growth, and the frequency of anomalies in vitro is the same as for conception in vivo.

Id.; Protection of Human Subjects: HEW Support of Human In Vitro Fertilization and Embryo Transfer: Report of the Ethics Advisory Board, 44 Fed. Reg. 35,033, 35,057, $35,044,35,056$ (June 18, 1979). The same holds true for children conceived by artificial insemination. See Lori B. Andrews, Legal and Ethical Aspects of New Reproductive Technologies, 29 CLIN. OBSTETRICS \& GYNECOLOGY 190, 197 (1986) (reporting that a French study conducted in 1983 of 2052 children conceived by artificial insemination "found a lower malformation rate than among children conceived normally [i.e., sexually].").

507. The recent case of a child conceived by IVF in order to save his sister, who needed a bone marrow transplant, is a case in point. See Denise Grady, Son Conceived to 
risk of a deformed embryo ultimately being born can be reduced by a simple visual examination. These early-stage embryos identified as possessing potential defects would likely not be implanted into the womb; rather, consistent with current legal principles concerning early stage in vitro human embryos, these high-risk embryos created by cloning could (and likely would) be discarded, just as they currently are in the context of IVF. ${ }^{508}$

The question remains, however, as to whether cloning would pose a greater risk of physical defects than the techniques employed with IVF. It is perhaps virtually impossible to answer this question, given the limited experience with cloning techniques. Thus, opponents of human cloning feed upon this fear of the unknown, speculating in a vacuum, shifting the burden onto proponents of cloning to prove a negative--that cloning does not pose a greater risk than IVF. Such speculative fears are not sufficiently compelling to justify governmental interference with fundamental liberties. ${ }^{509}$ As Justice Brandeis once stated, "Fear of serious injury alone cannot justify suppression of free speech and assembly. [Because of fear] [m]en feared witches and burnt women." 510 Likewise, in Tinker v. Des Moines Community School District, ${ }^{\text {sll }}$ the Court stated that "undifferentiated fear" was not sufficient to justify restriction of the fundamental right to freedom of expression, reasoning that "[a]ny variation from the majority's opinion may inspire fear." 12 Likewise, in the context of human cloning, speculative fear, born of variation from the majority's opposition, should not be sufficient to justify total prohibition. Indeed, if such majoritarian fears could serve as a valid basis for the infringement of fundamental liberties, these liberties would not be long lived.

Even assuming arguendo that human cloning would present a risk to the health or safety of the future child, a complete ban on human cloning would not be sufficiently narrowly tailored to withstand strict scrutiny. A more narrowly tailored approach would be to establish standards to minimize risk to embryos created by cloning, such as minimum qualifications for procedure, personnel, and equipment. Such standards would tend to restrict indirectly the fundamental right of procreation ${ }^{5 / 3}$ but would also serve a compelling interest in health and safety

Provide Blood Cells for Daughter, N.Y. TIMES, Oct. 4, 2000, at A24. The embryo conceived by IVF was selected for implantation after microscopic examination revealed that the embryo did not have the genetic disease of his sister (fanconi anemia) and shared his sister's tissue type. Id.

508. For a more detailed discussion of the incidence of discarding human embryos created by IVF, see supra notes 154-157 and accompanying text.

509. See Stanley v. Georgia, 394 U.S. 557, 566-67 (1969) (concluding that "[g]iven the present state of knowledge" there "appear[ed] to be little empirical evidence" to support Georgia's assertion that prohibiting the possession of obscene materials would prevent deviant sexual behavior and crimes of sexual violence).

510. Whitney v. California, 274 U.S. 357, 375-76 (1927) (Brandeis, J., concurring).

511. 393 U.S. 503 (1969).

512. Id. at 508.

513. Cf. Planned Parenthood of Southeastern Pa. v. Casey, 505 U.S. 833, 874

(1992). The court found: 
and would be narrowly tailored to further such interests. Congress has already enacted analogous general quality standards for clinical laboratories which receive Medicare or Medicaid funds. ${ }^{514}$ Moreover, in an attempt to provide consumer information regarding the quality of facilities performing IVF, Congress enacted a law requiring such facilities to report their standardized success (i.e., live birth) rates, which are then published annually by the federal government. ${ }^{515} \mathrm{~A}$ similar law requiring the dissemination of success rates for cloning would provide an incentive for such facilities to minimize risk and maximize live birth rates. Because more narrowly tailored means exist that could ensure that human cloning is conducted in a safe manner, a total prohibition on human cloning would likely be unconstitutional.

\section{E. Preserving Genetic Diversity}

Perhaps the least moralistic objection to human cloning is that it would threaten human genetic diversity, leaving mankind more vulnerable to certain diseases and conditions. ${ }^{516}$ The argument is that if the practice of human cloning becomes sufficiently widespread, there would be a corresponding decrease in the variation of human genotypes, since certain "preferred" genotypes would simply be cloned rather than "mixed" with other genotypes to produce an "unknown" product. 517 The repeated perpetuation of these preferred genotypes would leave humankind "toast for germs." 518 This objection, if well founded, would likely be considered a sufficiently "compelling" governmental interest to justify some regulation of human cloning. If, however, human cloning does not become

Numerous forms of state regulation might have the incidental effect of increasing the cost or decreasing the availability of medical care, whether for abortion or any other medical procedure. The fact that a law which serves a valid purpose ... has the incidental effect of making it more difficult or more expensive to procure an abortion cannot be enough to invalidate it. Only where state regulation imposes an undue burden on a woman's ability to make this decision does the power of the State reach into the heart of the liberty protected by the Due Process Clause.

Id.

514. See Clinical Laboratory Improvement Act of 1988, 42 U.S.C. § 263a (1994 \& Supp. 1998.)

515. See Fertility Clinic Success Rate and Certification Act of 1992, 42 U.S.C. $\S \S$ 263a-1-a-7 (1994).

516. See, e.g., PENCE, supra note 33, at 129-31; see also Heimbach, supra note 414 , at 635 ("Cloning will make the entire human race more vulnerable to mutating infectious diseases, and the size of this danger will grow exponentially in relation to the rate at which human cloning actually reduces diversity in the gene pool for the race as a whole.").

517. See PENCE, supra note 33.

518. David Stipp, The Real Biotech Revolution: Biotech's Real Power Lies in Reading the Book of Life, Not Blindly Copying It, FORTUNE, Mar. 31, 1997, at 54. 
widespread, there is little or no objective basis for the feared loss of genetic diversity. ${ }^{519}$

Polls indicate that only about six to seven percent of Americans would want to clone themselves if the technology were available. ${ }^{520}$ These poll numbers translate into the possibility that sixty to seventy of every one thousand people would be willing to consider cloning thernselves. ${ }^{521}$ Of course, not everyone who wants or is willing to clone himself will actually do so; many would likely change their minds if given a real opportunity, either due to age, health, economics, or other personal considerations. Even assuming arguendo that one-third of those who indicate a willingness to clone themselves would actually do so given the chance, this results in a theoretical maximum ${ }^{522}$ of approximately twenty babies created by cloning per thousand people. ${ }^{523}$ And, of course, not every attempt at cloning would be successful. A certain percentage of embryos conceived by cloning that were implanted into a woman's womb would fail to thrive, just as a certain percentage of embryos conceived by other means fail to thrive. ${ }^{524}$ If the Dolly experiments are any indication, approximately one in thirteen attempted pregnancies would ultimately result in the birth of a child. ${ }^{525}$ Thus, of the estimated twenty persons per thousand that attempted human cloning and created a pregnancy, only around one to two of these pregnancies would actually result in a live birth. Those individuals who were unsuccessful at having a child by cloning after the first attempt would, of course, be free to try again. The likely expense and emotional costs involved in subsequent attempts, however, would likely deter many, as is evidenced by couples who undergo IVF.

Even if such numbers hold true for the worldwide population, they are not cause for concern about genetic diversity. The incidence of identical twins, for example, is estimated at one in every 270 births. ${ }^{526}$ Translated into comparative numbers, this means that approximately four of every 1000 births results in identical twins. This figure thus may provide an objective indicator of how much genetic duplication is tolerable; after all, no one seriously believes that twin births

519. But see Posner \& Posner, supra note 136, at 257-58 (employing an economic model to estimate the demand for human cloning and concluding that such demand is "impossible to estimate" but that "cloning may [] aggravate inequalities in genetic endowment and in wealth, undermine the already imperiled institution of marriage, alter the sex ratio, and create irresistible pressures for eugenic regulation.").

520. See SILVER, supra note 42 , at 117.

521. Of course there would potentially be other, additional individuals who might desire to engage in cloning, but not of themselves-for example, cloning of a deceased loved one or one's spouse. How many such people exist is unclear, but presumably not all such persons would actually be willing to fulfill their desires and engage in cloning activity.

522. This assumes all attempts at human cloning resulted in a live birth.

523. This is a maximum possible estimate, since presumably many implanted embryos created by human cloning would fail to thrive and either be reabsorbed or miscarried. For a more detailed discussion of the incidence of natural abortion, see supra notes $147-149$ and accompanying text.

524. See supra notes $142-150$ and accompanying text.

525. See supra note 144 and accompanying text.

526. See Hilgers, supra note 26 , at 36 . 
present a threat to human genetic diversity. In contrast to naturally occurring twins, approximately one to two of every 1000 births would result from human cloning, less than half the rate of twin births. Thus, even if we doubled the Dolly experiment success rates for cloning and assumed that up to four births per thousand were children conceived by cloning, the risk to genetic diversity posed by human cloning would be no greater than that posed by the birth of twins.

Another possible source for comparison would be statistics concerning repetitive sperm donation. Sperm donors often repeat donation, whether for egotistical or altruistic reasons. ${ }^{527}$ Indeed, one Virginia fertility specialist was discovered to have donated his own sperm to impregnate seventy-five of his infertile patients. ${ }^{528}$ The problem is sufficiently serious that the American Society for Reproductive Medicine (ASRM) recommends that IVF clinics not use the sperm of any donor to create more than ten offspring. ${ }^{529}$ Such a numerical limitation on the use of donor sperm, according to the ASRM, makes the risk of procreation amongst close blood relatives "essentially nonexistent" naturally reduces the risk of a loss of genetic diversity that might otherwise be caused by the repetitive use of a single individual's sperm.

There are, of course, strong pragmatic factors that would also tend to reduce the likelihood of a loss of genetic diversity by cloning. First, of the relatively small number of individuals who may be interested in procreation by cloning, an even smaller number would likely want to procreate by cloning multiple times. ${ }^{531}$ This is so because of the physical, emotional, and financial reality of having to bear each child (or finding a surrogate to bear each child), and then having to raise, feed, and educate each child. ${ }^{532}$ For those few remaining individuals who would want to have multiple children created by cloning but who would not want to play a role in their upbringing, e.g., giving the children up for adoption, a numerical limitation may indeed be normatively desirable. Thus, even if hundreds of thousands or even millions of individuals cloned themselves, their percentage of the total human population, currently approximately six billion, ${ }^{533}$ would be infinitesimal. ${ }^{534}$

527. Indeed, many repeat sperm donors are medical students. See FrOMER, supra note 27, at 263; ELIAS \& ANNAS, supra note 333, at 228.

528. The women apparently were not aware that the sperm they received was that of their own physician. See Sandra Anderson Garcia, Sociocultural and Legal Implications of Creating and Sustaining Life Through Biomedical Technology, 17 J. LEGAL MED. 469, 478,494 (1996).

529. See AFS Report, supra note 153, at $44 \mathrm{~S}$.

530. See id. at $45 S$.

531. For a more detailed discussion of the likely incidence of human cloning, see supra notes 518-521 and accompanying text.

532. Assuming, of course, that artificial wombs do not exist.

533. See David Briscoe, Almost Six Billion Birthed Here on Fast-Brood Planet, AUSTIN AM.-STATESMAN, May 30, 1999, at A22.

534. See PENCE, supra note 33, at 130. 
In addition, the availability of cloning would be unlikely to reduce significantly the attractiveness of procreation by intercourse. Gregory Pence puts it this way:

Boy meets girl once in the night and a child is conceived.... [T] he reality is that billions of existing people would create more people in the old way, mixing their genes with people originated by [cloning], with everyone ratcheting down to the mean. More practically, for every high-minded couple who produced a superior child by [cloning], there would be a Brazilian couple who produced nine children by normal sex..$^{535}$

Procreation by cloning, in other words, may provide a more attractive means of procreation for certain types of individuals, such as infertile couples, individuals with genetic disorders, or homosexuals. But for the vast majority of individuals, procreation the old-fashioned way will continue to be the preferred method. ${ }^{536}$

Moreover, as Lee Silver has pointed out, rather than endangering the human gene pool, cloning could potentially result in a positive net improvement by reducing the incidence of genetic diseases. ${ }^{537}$ Indeed, it is estimated that more than seventy percent of deaths may be traced to genetic causes. ${ }^{538}$ The chances of getting sickle cell disease, for example, is one out of 625 for African Americans. ${ }^{539}$ The chance of a person being a carrier for cystic fibrosis is approximately one in twenty-five. ${ }^{540}$ The chance of having a genetic predisposition to breast or prostate cancer is one in ten, respectively, for women and men. ${ }^{511}$ By cloning adults whose genome is known to be free of such genetic disorders, cloning thus presents a potential opportunity to improve rather than denigrate the human gene pool. ${ }^{542}$

Given the present paucity of objective information on the threat cloning poses to genetic diversity, it seems unlikely that "preserving genetic diversity" would be considered a compelling interest sufficient to justify a complete ban. If, however, such information becomes available, certain more narrowly tailored restrictions on human cloning may be permissible. John Robertson, for example, advocates the establishment of a specific legal limit on the number of children

\footnotetext{
535. Id.

536. See id.

537. See SILVER, supra note 42, at 220.

538. See PENCE, supra note 33, at 103.

539. See id.

540. See id.

541. See id.

542. See SMITH, supra note 29, at 106:

If the rate of pollution of the human gene pool continues to increase through uncontrolled sexual reproduction, however, efforts to produce healthier people may be required to compensate for the spread of various genetic diseases. In that event, one could make a strong ethical argument to justify cloning of healthy individuals on the ground that it could achieve the greatest good for the greatest number.

Id. (citations omitted).
} 
who may be produced by cloning a single source of DNA, ${ }^{543}$ analogous to the limits currently imposed by many infertility clinics for pregnancies created by the use of a single donor's sperm. ${ }^{544}$

\section{CONCLUSION}

If our Constitution does, in fact, give us the right to procreate by cloning, should we be afraid? Should we begin mobilizing politically in an attempt to pass a constitutional amendment via the procedures of Article $\mathrm{V}$ to ban human cloning? The answer should be "no," for several reasons.

First, the science fiction abuses associated with human cloning are unlikely to occur under current law, both statutory and constitutional. The current legal construct provides us with both the fundamental freedom to procreate as well as corresponding protections for the products of our procreation, our children, regardless of how they are conceived. Current law, in short, does not recognize genetic classification of human beings; if one is human, then one is entitled to all the legal rights enjoyed by other humans.

Second, the primary objections to human cloning appear to be unfounded, based more on morality, theology, and fear than objective data. Such subjective notions should not provide the sort of important or compelling interest sufficient to justify infringement of constitutional rights. Finally, even assuming that banning human cloning would serve one or more important or compelling governmental interests, such a law may nonetheless be unconstitutional because there are numerous, more narrowly tailored means-short of a total prohibitionby which to effectuate such ends.

Banning human cloning sends the regrettable message that politics and public pressure triumph over logic and the law. If citizens and lawmakers can just remember that clones are people, too, we can face this brave new world, confident that our laws are adequate to carry us all, safely, into the twenty-first century.

543. See Robertson, supra note 321 , at 1451 . He asserts that "[a] limit of no more than three clones born from DNA is a reasonable line, although other numbers might also reasonably be chosen as well." Id.

544. See supra notes 527-528 and accompanying text. 